\title{
THE DAKOTA STAGE OF THE TYPE LOCALITY
}

by .

ALLEN C. TESTER 



\section{TABLE OF CONTENTS}

PREFACE -

Chapter I. Introduction _....... 200

Chapter II. The Type Section of the Dakota Stage

Chapter III. Review of Previous Work-_._-_._-_._- 204

Chapter IV. The Use of Rock Terms for the Dakota

Chapter V. Description of the Exposures in the Type Area

Section 1. Pits of Sioux City Brick Company-_-_.

Section 2. Old quarry near Stone Park-_-_-_-_-_-_-_-_-_-_-_-_-_- 240

Section 3. Crill mill section-_.

Section 4. Prospect Hill outcrop, Sioux City-_-_-_-_-_-_-_-_-_-_-_-_- 243

Section 5. Sergeant Bluff pits

Section 6. Elk Point Ferry Landing, Ponca, Nebraska_-___-_._-_._-_ 246

Section 7. Missouri bluff, southeast of Ponca-_-_-_-_-_-_-_-_-_-_-_. 247

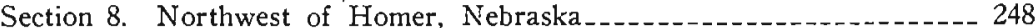

Section 9. Southeast of Homer-_-_-_-_-_-_-_-_-_-_-_-_-_-_-_-_ 249

Section 10. South of Homer-.- 250

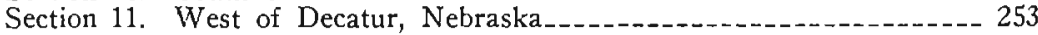

Chapter VI. The Dakota Rocks of Adjacent Areas

Section 12. Near Lewis, Iowa-_o-_.

Section 13. Near Coburg, Iowa

Section 14. Near Fairbury, Nebraska--

Section 15. Washington county, Kansas

Chapter Vil. Interpretations of the Condrtions of Deposition of the

Dakota Stage of the Type Area The position of the Dakota stage in the Upper Mesozoic sequence -

Chapter Vili. An Experimental Study of Fluvial Sorting and Deposition 285

Stream table experiment No. I

Stream table experiment No. II

Stream table experiment No. III

Appendix A. Laboratory Methods Used in the Analysis of Dakota Sands 302

Outline of Analytical work

Discussion of procedure

A. Field sampling - 303

B. Splitting samples for analysis

C. Preparation of samples.. 304

D. Mechanical analysis

A. Preparation of specimen._. 305

B. Separation by settling

Supplementary notes -

E. Mineral separation 307

F. Mineral determinations

Appendix B. Bibliograpty

Part I. Articles relating to type area of Dakota stage-

Part II. General references

Descriptions of Plates III and IV 


\section{LIST OF ILLUSTRATIONS}

FIGURE PAGE

25. Map of the area adjacent to the type locality of the Dakota stage

26. Mechanical analyses of sediments in type area.....

27. Regular foresets in section at Coburg, Iowa....... 256

28. Sandstone layers in exposure at Coburg

29. Details of layers in section at Coburg- 258

30. Details in lower part of Coburg section_... 259

31. Erosion of clays and sands of Comanchean age, Ellsworth county, Kansas

32. Regularly cross bedded sandstone west of Carneiro, Kansas._._._._._._. 270

33. Rocktown Channel Sandstone member interfingering with clays and sands.

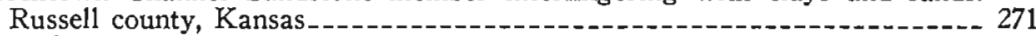

34. Crossbedding in Rocktown Channel Sandstone member. Russell county,

Kansas - 271

35. Crossbedding in exposure in Ellsworth county, Kansas........ 272

36. Mechanical analyses of Dakota sandstone

37. Analysis of source material for experiment I

38. Mechanical analyses of deposits in experiment $I_{2}$

39. The river at an early stage of experiment II

40. View showing location of samples in experiment II $_{-}$

41. Detailed view of central part of stream_- 292

42. Mechanical analyses of deposits in experiment II

43. Position of bars in stream in plaster of paris channel

44. Mechanical analyses of deposits in experiment III _._. 299

PLATE

PAGE

III. Photomicrographs showing minerals from Sioux City shale pit and Crill mill section - 323

IV. Photomicrographs showing minerals from Nebraska sections 7 to 10 


\section{THE DAKOTA STAGE OF THE TYPE LOCALITY PREFACE}

The data and conclusions presented in this paper represent a small amount of the material which the writer has accumulated on the subject of the Dakota rocks. The first field work was done in 1924 as a general study of the Dakota stage in Kansas under the auspices of the Kansas Geological Survey. In 1926 arrangements were made with the Iowa Geological Survey to make field investigations of the Dakota rocks in northwestern Iowa and adjacent parts of Nebraska and South Dakota. During subsequent years some additional studies were made in Kansas, Nebraska and Iowa.

In Chapter VI numerous references are made to the Dakota rocks of Kansas with the hope that such information will be valuable in understanding the interpretations made of the Dakota rocks of the type locality. The writer wishes to make acknowledgment at this time to the Kansas Geological Survey for the use of such material. A complete report on the Dakota rocks of Kansas is now being prepared and will be published by the Kansas Geological Survey. Additional studies were made during the 1930 and 1931 field seasons for this report and the mapping of the formations of the Dakota will be completed in 1932.

It was a fortunate arrangement that permitted the writer to study the Dakota rocks from southern Kansas, across Nebraska, and in northwestern Iowa, independent of state boundaries. The problem is one which is distinctly of a regional nature and the student should not be handicapped by artificial boundary restrictions. 


\section{CHAPTER I \\ INTRODUCTION}

Interest in the Dakota sandstone and its associated clay and silt members is almost as old as the study of stratigraphy'in the United States. Because of the excellent exposures of the basal Cretaceous rocks along one of the main routes of early travel and exploration it is not unusual that we find records of observations made along the upper Missouri river in the early part of the nineteenth century. The very fact that at least four principal divisions of the Cretaceous of North America have their type localities in the upper Missouri river country is significant of the work accomplished by the early explorations.

The writer has spent a part of five field seasons at intervals during the last eight years studying the various phases of the formations discussed in this paper. The work has not been confined to Iowa but has also included a critical study of the beds in Nebraska, Kansas and South Dakota and finally some observations in Colorado and New Mexico. The first work was done in Kansas, where the Dakota had been separated from the marine Belvidere formation of Washita age. Because of certain close relationships between the Belvidere formation and beds usually classified with the Dakota, it seemed logical that a careful study should be made of the type exposures of the Dakota along Missouri river. The data and conclusions presented in this paper are the results primarily of observations made in northwestern Iowa, northeastern Nebraska, and eastern South Dakota. With the exception of a few general stratigraphic studies in conjunction with quadrangle or county mapping the work of Gould in 1900 was the last regional study made of the Dakota in the area under consideration. It is not unusual then that some new facts would be obtained and new interpretations made with the more modern background available in the field of geology.

Of the recent investigations on the lower Cretaceous formations in the Middle west, the work of Twenhof ${ }^{1}$ has been especially helpful.

1 Twenhofel, W. H., Geology and Invertebrate Paleontology of the Comanchean and "Dakota" Formations of Kansas: State Geol. Survey of Kansas, Bull. 9, 1924, 135 pp., ills. 
He made a careful restudy of a complex section and on the basis of fossil identifications showed that certain horizons commonly described as Dakota should be correlated with the Washita formation of Oklahoma and Texas.

In the type locality of the Dakota sandstone, which for all practical purposes includes the exposures in Iowa at Sioux City, the marine fossils belong to the fauna which occurs in Kansas. For this and other' reasons it will be shown that the Dakota sandstone represents formations that include a part of the Comanchean and Cretaceous systems of some writers, and that no such division into systems can be justified. 


\section{CHAPTER II}

\section{THE TYPE SECTION OF THE DAKOTA STAGE}

Meek and Hayden were the first to make geologic sections of the rocks exposed along the upper Missouri river. As a part of their description they made divisions which ultimately became the type divisions of the upper Cretaceous of the central interior of the United States. The term "Dakota Group" was first applied in $1861^{2}$ to that part of the section which had previously been called "Formation No. 1 ". 3 As a part of their system of using geographic names for rock formations, Meek and Hayden gave as the type locality of the "Dakota group" the "Hills back of the town of Dakota; also extensively developed in the surrounding country in Dakota county (Nebraska) below the mouth of Big Sioux River."4

The final description of the Cretaceous rocks of the Upper Missouri country was given in a paper presented to the Philadelphia Academy of Natural Sciences in $1861^{3}$ and was repeated in the comprehensive report of Meek in $1876 .^{\circ}$ The only changes from the earlier publication were of punctuation, the correction of one generic name, and the addition of one new species. For the sake of accuracy the later ${ }^{7}$ description is given below :

"Yellowish, reddish, and occasionally white sandstone, with, at places, alternations of various colored clays and beds and seams of impure lignite; also silicified wood, and great numbers of leaves of the higher types of dicotyledonous trees, with casts of Pharella(?) $d a-$ kotensis, Trigonarca siouxensis, Cyrena arenarea, Margaritana nebrascensis, etc."

The localities of exposure and study:

"Hills back of the town of Dakota; also extensively developed in the surrounding country in Dakota county below the mouth of Big. Sioux River and thence extending southward into northeastern Kansas and beyond."

In many respects it is unfortunate that this series of rocks, which

\footnotetext{
2 Meek and Hayden, Phila. Acad. Nat. Sci. Proc., 1861, Vol. 13, p. 419, 1862. See also Meek, F.B., U.S.G.S. Terr., Vol. 9, p. 25, 1876.

8 Meek and Hayden, Phila. Acad. Nat. Sci. Proc., Vol. 8, pp. 63-69, 1856; Vol. 9, pp. 117-148, 1857. See also Hayden, F.V.. Phila. Acad. Nat. Sci. Proc., pp. 109-116, 1857,

4 Op. cit., Phila. Acad. Nat. Sci. Proc., Vol. 13, p. 419, 1861.

5 Meek and Hayden, Phila. Acad. Nat. Sci. Proc. 1861, p. 419, 1862.

Meek, F. B., U. S. G. S. Terr., Vol. 9, p. 25, 1876.

7 Meek, F. B., Idem. p. 25.
} 
has been so widely described and correlated, should have been given the name Dakota. It is true that the rocks are exposed in Dakota county, Nebraska, and that sandstones are exposed some six miles west and southwest of Dakota City, the county seat, but much better exposures and more complete sections are found on the Iowa side of the Missouri and along the bluffs facing Big Sioux river. A much more appropriate name would have been "Sioux" group or stage, because of the excellent exposures along Big Sioux river and adjacent to the then growing village of Sioux City, and also because the area was at the gateway to the Sioux Indian nation lands. The term is now used to designate the Sioux quartzite of pre-Cambrian age but was available at the time the Dakota was named. 


\section{CHAPTER III}

\section{REVIEW OF PREVIOUS WORK}

The literature on the Dakota stage is very extensive. The name, as commonly_used, has been applied to a sandstone and shale formation lying at the base of the marine Benton formation throughout the central interior of the United States and on both sides of the Rocky Mountains. The scope of the present paper does not consider these wide correlations, hence it is impractical to discuss the Dakota beyond the type area. All of the available literature dealing with the lowest of the Cretaceous rocks in northeastern Nebraska and adjacent Iowa has been studied, and these references comprise Part I of the bibliography.

The reprints of the original journals of the Lewis and Clark expedition up Missouri river in $1804-1806^{8}$ are disappointing in their content of notes on the geology of the region traversed. It is probably true that the short delay caused by the death. of Sergeant Floyd just below the present site of Sioux City caused Lewis and Clark, and other members of the party who kept journals, to record the topography of the region and the general character of the rocks and to do some collecting of rock and mineral specimens.

Captain Clark in his original account ${ }^{9}$ describes a rock formation at a locality north of the present village of Decatur, Burt county, Nebraska. This is probably the earliest printed account which calls attention to the Dakota rocks adjacent to the type area. He relates noticing a "yellow, soft sandstone" in the bluffs on the west side of Missouri river near the place of the Mahar (Omaha) Indian Chief Blackbird burial mound. Again, in the diary for the following day (August 12, 1804), he tells of seeing the soft sandstone in the west bluff and observes that many springs issue from the sandrock. The last locality is probably about four or five miles southeast of Homer, Dakota county, Nebraska.

An interesting note is given in Clark's journal for August 22, 1804, ${ }^{10}$

8 Thwaites, Reuben Gold, Original Journals of Lewis and Clark, 1804-1806. New York, 1904. 7 vols.

9 Idem, Vol. I, p. 106

10 Op. cit., p. 116. 
following the death and burial of Sergeant Floyd. He tells about seeing in the rocks "copperas, cobalt, pyrites; an alum rock, soft and sandstone. Capt. Lewis determined the cobalt, which had the appearance of soft Isonglass." The best determination which the writer can make places this locality 15 to 18 miles above Sioux City, possibly near the mouth of Aowa creek, and the formations may be either the upper part of the Dakota or the base of the Graneros. Seven miles farther upstream Clark describes "a Clift of allom stone of a Dark Brown colr. containing also incrusted in the crevices and shelves of the rock great qts. (quantities) of Cobalt, Semented Shels \& a red earth". ${ }^{11}$ (The spelling and capitalization are the same as in the original journal.) This is probably the steep bank north of Ponca, Nebraska.

The various scientific observations made by Lewis and Clark are contained in volume 7 of the Thwaites edition. The notes on Mineralogy were edited by Prof E. H. Barbour of the University of Nebraska. The party collected some shells and various rock and mineral specimens and on their return deposited them with the American Philosophical Society. ${ }^{12}$ The shells were not described and the crude determinations by Lewis of the minerals made the collections of little value.

Meek $^{13}$ states that Nuttall and Long brought back Cretaceous fossils from their expeditions into the upper Missouri country in 1809 and 1819 respectively. These shells were not studied and identified until several years after the return of the explorers, and they did not aid in the recognition of the age of the rocks while in the field.

The journeys of Bradbury and Nuttall in 1809-1810 into the upper ${ }^{\circ}$ Missouri river country contributed little of value concerning the rocks of the Sioux City area. Bradbury was not interested in geology, and Nuttall was a better botanist than geologist. In Bradbury's book published in London in 1817, ${ }^{14}$ there is a description of the reddish bands in the rocks which he called hematite. As this feature was noted near the Yankton Indian villages and below Niobrara river, it is possible that the rocks observed belong to the Dakota stage.

The first published work of Nuttall concerning his trip into the upper Missouri country appeared in $1821^{13}$ and shows an effort to correlate the formations exposed along the river with other rocks which Nuttall had observed in Arkansas territory and elsewhere. He says: "While

11 Idem, p. 117.

12 Idem, Vol. 7.

13 Meek, F. B., U.S.G.S. Terr, Vol. 9, p. 21, 1876

14 Bradbury, John. Travels in Interior of America in 1809-1811

15 Nuttall, T., Phila. Acad. Nat. Sci. Jour,, Vol. 2, pp. 14.52, 1821. 
ascending the Missouri in the summer of 1810 , I could not ascertain the existence of the compact calcareous rock, containing organic reliquiæ, beyond the confluence of the river. Platte; yet the sandstone hills and woodless plains in the rear of the Maha village, were precisely such as we met with along the northern borders of the Arkansas within the limits of Pottœ, and the Saline rivers."18 In this instance he was probably referring to the Dakota sandstones of central Kansas. If this is the case, it is the first correlation of the sandstone series of northeastern Nebraska with those of central Kansas.

Farther up the river Nuttall collected a fossil Ostrea and an unknown species of Baculites from the bluish gray clay "abounding in pyrites and xylanthrax." In describing the calcareous cliffs not far from the creek of the Maha village, he says they "more closely resembled chalk than anything of the kind which I have heretofore seen or heard of in North America, but cannot by any means be identified with the same formation in the south of England and in France. We could not discover in it any organic reliquiæ, nor any vestiges of flint."17 In spite of this statement recent writers have given Nuttall credit for being the first to recognize the chalk of North America as being correlative with similar beds in England and also claim he recognized the beds along Missouri river because of their fossil content.

Keyes in Vol. XXII, Iowa Geological Survey, 1913, page 50, says: "Another important geologic correlation is to be credited to Nuttall. On his journey up the Missouri river in 1810, which he undertook with John Bradbury, a Scotch naturalist, he reached the Mandan villages on the upper reaches of that stream. He makes especial mention of the Omaha villages situated below the mouth of the Big Sioux river. A short distance upstream from the last mentioned point he examined strata which by means of their fossils presumably, he referred to the Chalk division of the Floetz or Secondary rocks of northern France and southern England. This is the earliest definite recognition of beds of Cretaceous age in America." It seems true that Nuttall used the principle of William Smith in the correlation of formations by their fossil content in the case of the Mississippian rocks (p. 14 of Nuttall) but he failed to find the fossils which would permit him to do the same for the Cretaceous rocks of the upper Missouri country. The word 'Maha' used by Nuttall and others was the common usage for the present word Omaha, as used by Keyes.

Thomas Say, in the report of Edwin James on the Long expedition

16 Idem, p. 24.

17 Nuttal1, op. cit., p. 25. 
to the Pacific, ${ }^{18}$ identified and described shells obtained by Thomas Nuttall in 1819 from "along the Kiamesha river in Arkansas." These are named Gryphaea corrugata and Ostrea. No mention is made of the strata being correlative with European beds.

Vanuxem was the first geologist in America to recognize the existence of strata in this country which could be correlated with the Cretaceous formations of England. Morton presented Vanuxem's notes to the Philadelphia Academy in $1828,{ }^{10}$ showing the latter's recognition of the age of the strata in New Jersey on the basis of the fossils. "The pelagian fossils by which this formation is characterized, affords ample evidence that it belongs to the Secondary and not, as commonly supposed, to the Tertiary class." ${ }^{20}$ The following year Vanuxem ${ }^{21}$ pointed out certain errors in Maclure's classification of the beds of the Atlantic coastal plain and showed that the 'alluvial' of Maclure contains littoral shells similar to those of the English and Paris basins and pelagic shells like those of the chalk deposits of England. With the correlation of Cretaceous rocks made along the Atlantic coast, it was not long until it was recognized that many of the fossils brought from the upper Missouri country, Arkansas and New Mexico came from beds of nearly the same age. Morton continued to contribute ${ }^{22}$ to the knowledge and classification of the "ferruginous sandstone formation" 23 of New Jersey and after comparing the fossils with those from the Green Sand of England was struck by the resemblance. His classification of the beds below the Tertiary is essentially the same as that used today. Finally, in 1833, Morton ${ }^{24}$ summarized the great progress which was then being made in the extension of the classification of the marl beds to include the formations of almost all the south Atlantic and Gulf states and extending into the Arkansas river country and upper Missouri country. He stated that Lewis and Clark, Nuttall, Col. Long and others "found Baculites, Hamites (?), Gryphaea and other marl fossils at the Great Bend of

18 James, E., "Account of Expedition from Pitsburg to the Rocky Mountains performed in 1819-1820. Description of fossils by Thomas Say, Vol. 1, p. 106, and Vol. 2, pp. 410-411. Phila., 1823.

18 Morton, S. G., Pbila. Acad. Nat. Sci. Jour., Vol. 6, 1828, pp. 59-71, 1829.

20 Idem, p. 62.

21 Vanuxem, I., Am. Jour. Sci., Ser. 1, Vol. 16. p. 254, 1829.

22 Morton, S. G., Am. Jour. Sci., Ser. 1, Vol. 17, pp. 274.295, 1830. See also Am. Jour. Sci., Vol. 18 , pp. $243-250,1830$.

23 At that time Conybeare and Phillips divided the ferruginous sandstone group of England into four divisions: (from top down) 4. Chalk marle, 3. Green Sand, 2. Weald Clay, 1. Iron Sand.

24 Morton, S. G., Am. Jour. Sci., Vol, 23, pp. 288-294, 1833. 
the Missouri river - - intimating the existence of the ferruginous sand in that remote region of our continent."25

Nicollet was the next geologist to report on the Cretaceous of the upper Missouri river country. He gives a section ${ }^{26}$ which he examined near the mouth of 'Ayoway' (Aowa) river. At the base of this section he found three feet of argillaceous limestone containing Inoceramus and disseminated iron pyrite, overlain by 30 feet of calcareous marl containing fish scales and a few other fossils. These rocks, he says, always constitute the base of the Cretaceous of the upper Missouri country and rest immediately on the Carboniferous limestone. Apparently Nicollet missed the Dakota sandstone entirely.

Sir Charles Lyell ${ }^{27}$ obtained some information concerning the Cretaceous rocks of the Missouri country from G. W. Featherstonhaugh and Prince Maximilian von Wied. However, Lyell's geologic map of the United States shows the base of the Cretaceous occurring higher on Missouri river than the type area of the Dakota sandstone.

Owen ${ }^{28}$ mentions the Cretaceous of the Sioux City area in recording a part of Evans' report to him. Evans saw the Cretaceous rocks near the mouth of Aowa creek and by using the lithological characters described by Nicollet was able to trace the beds beyond Fort Pierre. No detail is given concerning the Dakota, but several fossils are recorded in the younger beds.

Jules Marcou contributed many observations on the rocks of the western part of the United States and particularly of the Rocky mountain region. He published in $1855^{29}$ a long article explaining his geologic map of the United States. This was the first paper of any length which attempted a systematic explanation of the formations of the United States and, even with its many mistakes, was a distinct advance in the study of geology. In fact, the furor incited by Marcou's interpretations gave a great impetus to further investigations. His mapping of Triassic, Jurassic and Cretaceous formations especially was challenged, and much disagreement arose concerning his correlations. $\mathrm{He}$ made no observations on the upper Missouri river at this time so could contribute nothing new on the Cretaceous section of that locality.

\footnotetext{
25 Idem, p. 292

26 Nicollet, J. N., Am. Jour. Sci.. Ser. 1, Vol. 41, pp. 180-182, 1841

27 Lyell, Charles, Travels in North America, London, 1845.

28 Oven, D. D., Geologica! Survey of Wisconsin, Iowa and Minnesota, and incidentally a portion of Nebraska Territory; made under direction of U. S. Treasury Dept., p. 195, Phila., 1852 .

29 Marcou, J., Bull. Geol. Soc. France, Ser. 2, Vol. 12, pp. 813, 936.
} 
The first good study of the stratigraphic sequence of the Cretaceous beds of the upper Missouri country was published in 1856 by James Hall and F. B. Meek. ${ }^{30}$ The expedition which made this study was composed of Meek and Hayden, but the fossils collected were studied by Hall, who also made the figures for illustration. While descending Missouri river from Fort Pierre to near Omaha, particular attention was given to the lithological characters, the order of succession, and characteristic fossils of the various divisions of the Cretaceous. As a result of their studies the first stratigraphic section was obtained. For comparison it is given below. ${ }^{31}$

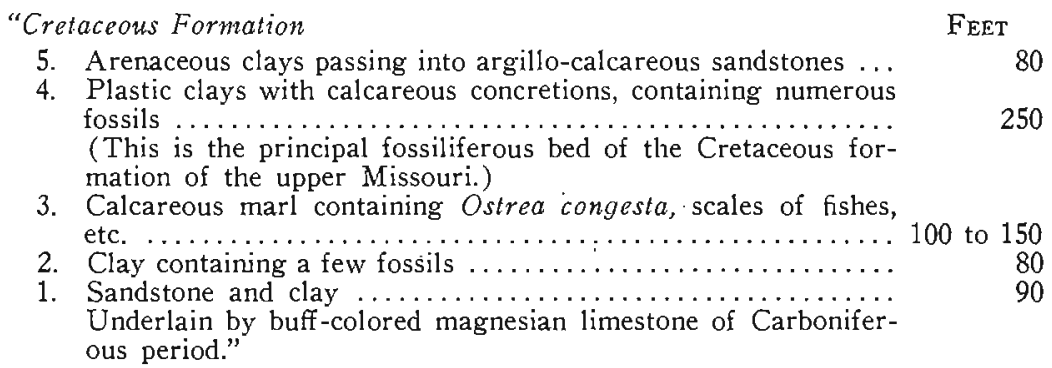

The thickness of the various beds is only approximate, having been derived from a study of the exposures seen in several localities. The reference cited contains many fine illustrations of fossils described and figured for the first time.

In $1856^{\mathrm{M}} \mathrm{Meel}$ and Hayden ${ }^{32}$ published their first joint article to include a stratigraphic section of the upper Missouri river Cretaceous. The five divisions are as follows:

"Cretaceous System : : FEeT

5. Gray and yellowish arenaceous clays containing great numbers of marine mollusca with a few land plants ................ 100 to 150

4. Plastic clays with numerous marine mollusca ............ About 350

3. Gray and yellowish calcareous marl, containing Ostrea con-

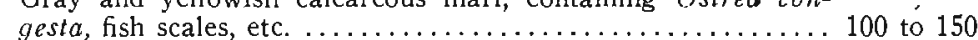

2. Grayish and lead-colored clays, having: few fossils ........ 80

1. Sandstones and clays not positively known to belong to the Cretaceous system .......................... $90^{\prime \prime}$

Limestones of the upper Coal Measures as observed near Council Bluffs, Iowa, underlie the section noted above. A description of 28 species of gastropods follows, but none of the forms comes from the lower three divisions.

The Dakota, as defined later by the same writers, is number one of

30 Hall and Meek, Am. Acad. Arts and Sci. Mem., Boston, N. S., Vol. 5, pp. 379.411, 1856.

82 Meek and Hayden, Phila. Acad. Nat. Sci. Proc., Vol. 8, pp. 63-69, 1856. 
the section. During the early studies of division number one Meek and Hayden were not certain concerning its proper age.

In a paper presented to the Philadelphia Academy in November, 1856, Meek and Hayden ${ }^{83}$ developed more fully the Cretaceous section of Nebraska Territory and gave a complete catalogue of the invertebrate remains described and identified up to that time from the Cretaceous and Tertiary formations of that region. The fossil lists include over 140 species from the five divisions. For formation No. 1 of the section (the Dakota) 17 species are listed, but 13 species are questionably referred to this formation. At this time certain exposures near the mouth of Judith river were correlated with formation No. 1, and most of the 17 species came from that locality. No invertebrates had been collected, at that time, from formation No. 1 at the mouth of Big Sioux river or the type area of the Dakota stage.

The principle of correlation by the use of fossils, and also of the differences of species in widely separated localities was well understood at this time, as is indicated by the comparisons made by Meek and Hayden. They say concerning the 147 Cretaceous species listed in their catalogue, "nine appear to be common to the Nebraska formations and those of the states, and four are identical with forms occurring in the old world." 84

Subdivision No. 1 of the Cretaceous system as given in this paper is quoted below :

"Heavy bedded yellowish sandstone, passing downwards into alternations of sandstone and clay, containing bits of waterworn lignite and bands of dark carbonaceous matter. This formation is not positively known to belong to the Cretaceous System."85

The thickness of this formation near the mouth of Big Sioux river is given as between 90 and 100 feet.

The next year Hayden elaborated still further on the Missouri river section. This description contains the names of three genera of mollusks collected from the locality near the mouth of the Big Sioux river. Dr. Hayden's section is as follows : ${ }^{36}$

"In order of superposition, Formation No. 1 rests directly upon the true limestones of the Coal Measures before referred to. Its first exposure seen along the Missouri is at Wood's Bluffs, right bank, about

83 Meek and Hayden, Phila. Acad. Nat. Sci. Proc., Vol. 8, pp. 265-286, 1856.

94 Op. cit., p. 266

35 Idem, p. 269.

so Hayden, Phila. Acad. Nat. Sci. Proc., Vol. 9, p. 111, 1857. 
eighty miles above the mouth of the Platte, and it dips beneath the water level of the Missouri, a few miles below the mouth of the Vermilion. Its general character is a coarse grained, friable sandstone, very ferruginous, of a yellow or reddish yellow color, with thin beds of impure lignite and various colored clay. It contains very few fossils, mostly of the genera Solen, Cyprina and Pectunculus, also fossil wood, and numerous impressions of dicotyledonous leaves, similar to the common willow. Its entire thickness is estimated at ninety to one hundred feet, but it may be more."

As indicated on the previous pages, Meek and Hayden entertained some doubts as to the proper age of formation No. 1 and placed it provisionally in their published sections' as a part of the Cretaceous system. After a careful review of the subject and more extended field work they were able to state in $1858,{ }^{37}$ with perfect satisfaction, that the formation could not be older than the Cretaceous. Their evidence for this was found partly in the modern affinities of the numerous dicotyledonous leaves which they found at numerous localities and partly in the stratigraphic relationships with the overlying formation number two.

At the time Meek and Hayden were accumulating their data for the determination of the age of formation No. 1, they traced the rock southward from Nebraska into Kansas to a point near Smoky Hill river. At this locality there are no rocks overlying the sandstones of formation No. 1, so they had no stratigraphic evidence relating it to formation No. 2 but were well satisfied with their correlation, as they state: "Our lithological and paleontological evidence is quite conclusive - - - for this rock in color, composition, and all other respects, is undistinguishable from number one of the Nebraska section, as seen near the mouth of the Big Sioux river on the Missouri, and contains numerous fossil leaves, some of which are identical with those appearing in number one at the last mentioned locality."

Dr. Newberry passed judgment on the age of the leaves mentioned in the above paragraph and was of the opinion that they are certainly Cretaceous, some of them belonging to genera peculiar to that time, and that the whole flora is of a more highly organized group of plants than anything known in the Triassic or Jurassic flora. As will be indicated on a later page of this paper, Meek and Hayden had been informed by Professor $\mathrm{Heer}^{39}$ that the leaves from formation No. 1 belonged to a Miocene flora.

37 Meek and Hayden, Phila. Acad. Nat. Sci. Proc., Vol. 10, p. 256, 1858.

38 Idem, p. 258 .

39 Heer, O., Phila. Acad. Nat. Sci. Proc., Vol. 10, pp. 265-266, 1858. 
In $1857 \mathrm{Hall}^{40}$ published his report on the geology and paleontology of the Mexican boundary and general observations on the Cretaceous strata of the United States. Hall reviews the general knowledge of the Cretaceous rocks of New Jersey, the south Atlantic and Gulf States and Nebraska. He refers to the collections of fossils made by the various explorers and geologists from the time of the Lewis and Clark expedition. He suggests that formation No. 1 of the Nebraska section is probably the equivalent of Nos. 1 and 2 of the New Jersey section, and also that it might be the equivalent of the various sandstones, shales and clays at the base of the formations in Llano Estacado. The main part of the paper deals with correlations of formations 2 and 3 of the upper Missouri river section, but for all the rocks Hall suggests the possibility of considerable variation in the thickness and lithologic character when traced over a wide area. He thought it very likely that some of the strata of the southwest were not represented in $\mathrm{Ne}$ braska and that others that were represented might be of different character.

For a period of several years a great controversy raged between Meek and Hayden and Newberry and their followers, and Marcou, Heer and other European geologists concerning the age of the various Cretaceous formations in Nebraska, Kansas, New Mexico, Texas and other western states. Regrettable as it was, the controversy caused new studies and observations to be made and yielded the classic sections of the Cretaceous of the upper Missouri river country, of which the Dakota section is one.

Hayden collected many dicotyledonous leaves from the sandstones along Missouri river, particularly those near Tekamah and in the exposures at Sioux City. In the absence of Dr. Newberry, Hayden sent sketches of these leaves to Prof. Heer of Zurich, who was somewhat surprised at their nature. Heer said there was nothing like these leaves in the European Cretaceous and thought they corresponded best to the lower Miocene of Europe. ${ }^{41}$ This started the controversy which did not end until Marcou and Capellini visited the Dakota type area in 186.3 and acknowledged the Cretaceous age of the rocks. ${ }^{42}$

In 1857 Meek and $\mathrm{Hayden}^{43}$ made correlations of their formation No. 1 of Nebraska with sandstones containing dicotyledonous leaves

\footnotetext{
40 Hall, J., Am. Jour. Sci, Ser. 2, Vol. 24, pp. 72-86, 1857; and U. S. 34th Cong., 1st Sess., S. Ex. Doc, 108 , House Doc. 135, pp. $126-138$.

41 Heer, Oswald, Proc. Phila. Acad. Nat. Sci., Vol. 10, 1858, pp. 265.266, 1859.

42 Marcou, J., Bull. Grol. Soc. France, 2 Ser., Vol. 21, pp. 132-146, 1864.

48 Meek and Hayden, Proc. Phila. Acad. Nat. Sci., Vol. 9, 1857, pp. 129-133, 1857.
} 
in Kansas, on the basis of sections and descriptions received from Major Hawn. In 1858. Meek and Hayden ${ }^{44}$ had the opportunity of studying these sandstones near the junction of Grand Saline and Smoky Hill rivers in central Kansas and of visiting other localities mentioned by Major Hawn. For the first time they were assured by direct observation that the Kansas sandstones could be correlated with their formation No. 1 of the Nebraska section. Major Hawn ${ }^{45}$ had called the Kansas beds Triassic. Newberry assured Meek and Hayden that the dicotyledonous leaves which they had collected from the Kansas localities were not of Triassic age, as they were much too modern.

Newberry, ${ }^{46}$ about the same time, crossed Kansas along the old Santa Fe trail on his route to New Mexico and had opportunity to visit some of the localities near Arkansas river reported by Meek and Hayden and repeated his judgment that the dicotyledonous leaves indicated Cretaceous rocks. Also, as a result of his New Mexico trip Newberry published in $1860^{47}$ a rather lengthy paper in which he refuted Heer's determination of Hayden's collection of leaves from Nebraska. Newberry had a very wide field experience and had seen the leaf-bearing rocks directly overlain by unquestionable marine Cretaceous rocks in many localities from the Atlantic coast to the central interior and in the Rocky Mountain states. His appeal for proper classification was strong, but he realized the prestige of Prof. Heer as a paleobotanist. Heer ${ }^{48}$ answered Newberry and maintained the Miocene age of the leaves submitted to him for study. It is evident, however, that he realized the possibility of a mistake, especially as he had only diagrams to study. He made a suggestion that the American geologists might have overlooked the possibility of great thrust faults causing the marine Cretaceous to be superposed on the Miocene. He called attention to the great thrust faults in the Alps, which have caused equally great displacements of strata. Not having had field experience in the central part of the United States, Heer could not realize the fallacy of such a postulation.

In 1863 when Marcou, ${ }^{49}$ accompanied by Capellini, visited the Sioux City area and studied other exposures of the Cretaceous along Missouri river, he concluded that the leaf-bearing beds were of fresh water

44 Meek and Hayden, Am. Jour. Sci., Ser. 2, Vol. 27, pp. 31-35, 1859.

45 Hawn, Frederick, St. Louis Acad. Sci. Trans., Vol. 1, pp. 171-172, 1858.

46 Newberry, J. S., Am. Jour. Sci., Ser. 2, Vol. 28, pp. 293-299, 1859.

47 Newberry, J. S., Am. Jour. Sci., Ser. 2, Vol. 29 , pp. 208-218, and Vol. 30, pp. 273.275, 1860

48 Heer, Oswald, Am. Jour. Sci.. Ser, 2, Vol. 31. pp. 435.440. 1861.

49 Marcou, J., Bull. Geol. Soc. France, Ser. 2, Vol. 21, pp. 132-146, 1864 
origin, but, as they are overlain by marine Cretaceous without any kind of discordance, that they also must be of Cretaceous age. However, he believed that the series of sands were to be correlated with younger beds of the European Cretaceous, that is, the Senonian of D'Orbigny, or possibly the Turonian. He states also that there are older beds in Arkansas, Texas and Oklahoma (along Canadian river), and he thought these beds to be the same as the green sands of Europe, or Neocomian.

In the meantime Meek and Hayden had restudied the Cretaceous exposures and published their final section of these rocks of Nebraska in $1862 . .^{50}$ They gave the name Dakota group to formation No. 1 and reiterated their belief in its Upper Cretaceous age. At this time Meek and Hayden thought the Dakota, Fort Benton and Niobrara groups to be the equivalent of the lower or Gray Chalk and upper Green Sand of the British geologists or the Turonian and Cenomanian of D'Orbigny. ${ }^{51}$ In commenting on the Dakota, the authors of the name wish it to be understood "that we do not regard the several rocks to which we have applied the names 'Dakota group', 'Fort Benton group', etc., as being always separately and individually recognizable at widely distant parts of the world, nor even in all cases throughout North America". ${ }^{52}$ That Meek and Hayden recognized at this early date that the Dakota stage was not a simple or distinct division is indicated in their statement that: "Although we still retain this as a distinct rock, our present impression is that it is probably only a subdivision or member of the Fort Benton group."53

Meek was not able to agree with Marcou on the fresh water origin of the Dakota formation. Marcou felt that the presence of the dicotyledonous leaves and the mollusk Cyrena (which he called $C$. novamexicana) were certain indicators of a nonmarine environment. Meek, however, points out ${ }^{54}$ the fact that Cyrena arenarea (as identified by Meek and Hayden) occurs with Pectunculus, Mactra siouxensis and a Pharella, and it cannot be fresh water alone. Pectunculus and Mactra are marine genera and Pharella and Cyrena are brackish water genera, hence Meek concludes: "The rock was deposited in a bay or estuary, which must have been alternately brackish and salt enough to sustain marine mollusks. The nature of the sediments composing it, as well

\footnotetext{
50 Meek and Hayden, Phila. Acad. Nat. Sci. Proc: for 1861, pp. 415-447, 1862

51 Idem, p. 419.

52 Idem, p. 420.

54 Meek, F. B., Am. Jour. Sci., Ser. 2, Vol. 39, pp. 157-173, 1865.
} 
as the numerous leaves and even trunks of trees, at some places found in it, attest the fact of its being a shore deposit." be very definite in his correlation of the Dakota of the Missouri river section, as he says that it is the exact equivalent of the leaf-bearing beds on Raritan river, New Jersey, which form the inferior member of the Cretaceous rocks of that state.

Capellini and $\mathrm{Heer}^{56}$ published the results of their new studies of the Cretaceous leaves in 1866. The paleobotanists agreed that the Dakota is Cretaceous but maintained that the zones containing the leaves were deposited by fresh water. So far as they were concerned this settled the dispute as to the age of the beds which Heer had first called lower Miocene.

Lesquereux confirmed in $1868^{57}$ the conclusions of Newberry and the other American geologists, when he identified the collections of dicotyledonous leaves from Tekamah and the type area of the Dakota as being of Cretaceous age.

White, in his Geology of Iowa, ${ }^{58}$ describes briefly the Cretaceous section and makes three subdivisions "and with no intention of superseding the names in their general application which these gentlemen (Meek and Hayden) have proposed for the more general subdivision of the strata where they are more fully developed."59 From top to bottom he called these divisions " (3) Inoceramus beds, 50 feet thick, (2) Woodbury sandstones and shales, 150 feet thick, and (1) Nishnabotany sandstone, 100 feet thick." These names did not receive common usage, except locally in Iowa, and have been abandoned because of the priority and more specific application of the Meek and Hayden terms. The type locality of the Nishnabotna sandstone was taken to be along East Nishnabotna river in Page, Montgomery and Cass counties and was thought, at the time it was proposed, ${ }^{60}$ to represent beds older than any exposed in the type locality of the Dakota series. The Woodbury sandstones and shales comprised all the beds from the base of the Sioux City section to the calcareous shales containing abundant Inocerami. White would have put into one formation the Dakota and lower Benton shales of Meek and Hayden. ${ }^{61}$

\footnotetext{
56 Idem, p. 172 .

56 Capellini and Heer, Mem. Soc. Helvetique des Sci. Nat., t. 22, pp. 1-24, 1866.

57 Lesquereux, L., Am. Jour. Sei., Ser. 2, Vol. 46, pp. 91-105, 1868.

58 White, C. A., Geology of Iowa, Vol. 1, pp. 285-295, 1870.

59 Idem, p. 289

60 White, C. A., Am. Jour, Sci., Ser. 2, Vol. 44, p. 23, 1867

B1 White, C. A., Geology of Iowa, Vol. 1, p. $291,1870$.
} 
In his report on the Geology of Woodbury county ${ }^{82}$ White gives several sections from exposures at or near Sioux City. His section taken at Cedar Bluffs (which is now a part of Stone Park), on Big Sioux river, is also given as a generalized section for the Sioux City area ${ }^{63}$ This section shows 80 feet of Woodbury sandstones and shales and is similar to the Meek and Hayden sections, though somewhat more detailed. The name Woodbury is not used by the Iowa geologists, as by its original definition it did not have stratigraphic value but included two different formations previously divided.

In 1891 the Cretaceous correlation paper by White ${ }^{64}$ appeared. Mention is made of the type section, and references are made to the original description by Meek and Hayden and to their general statements concerning the formation elsewhere. At this time there seemed to be no doubt concerning the correlation of the Nebraska Dakota and similar rocks elsewhere. This surety is indicated by the following quotation from White: "The Dakota formation is so well defined that no difference of opinion as to its identity, characterization, and delimitation has ever arisen among geologists who have studied it in the south interior region." ${ }^{66}$

The first indication that the Dakota formation might be much thicker than the observed exposures in the Sioux City area came from the study of well records and cuttings. Meek and Hayden apparently had some such information available, as their section of 1861 gave a thickness of 400 feet for-the Dakota. Todd ${ }^{66}$ in 1890 gives the records of two wells which are useful in determining the thickness of the Dakota. The well drilled at Ponca, Nebraska, started at 1175 feet elevation and was drilled 698 feet deep. A portion of the log below 80 feet of drift clays is repeated below. ${ }^{67}$

Chalkstone, capped with siliceous layers, Inoceramus beds ......... 45

Alternate layers of fine, stratified sand and light and drab clay. A pretty compact stratum with a layer of lignite above, sometimes for a little

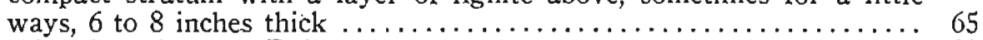

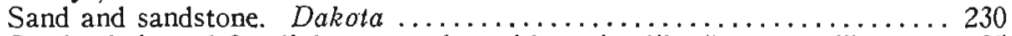

Sandy shale and fine light green clay with grains like "greensand" ..... 35

Rusty, gray, porous limestone, and other limestones which are probably all Pennsylvanian continue to the bottom of the well.

Todd apparently correlated the upper Chalkstone horizon with

62 White, C. A, Geology of Iowa, Vol. 2, p. 186, 1870

68 Idem, pp. 196-197.

64 White, C. A., U. S. G. S. Bull. 82, pp. 140-164, 1891

66 Idem, p. 164, Iodd, E., Iowa Acad. Sci. Proc., Vol. I, part ii, pp. 13-14, 1892.

67 Todd, op. cit., p. 13 . 
White's Inoceramus beds, and the balance of the beds down to the limestone would be included in White's Woodbury sandstones and shales, making a total of 330 feet of this formation underlying Ponca, Nebraska. Todd's descriptions of the formations are very interesting, but it is doubtful if there are 230 feet of sand or sandstone in the section, as all other sections in the region do not indicate such a purity of materials. The lowest Cretaceous in the well record, which. Todd describes "with grains like 'greensand" ", may have considerable significance. From observations elsewhere the writer believes the grains are glauconite.

A well at Sioux City which starts below the top of the Dakota shows 191 feet of sand and sandstone which Todd $^{68}$ calls Dakota; the Le Mars well shows 147 feet of the same material; and it is believed that 109 feet of dark gray sand at Emmetsburg is the equivalent of the Dakota.

Calvin ${ }^{60}$ made an important" contribution in 1892 when he reviewed the classifications of the Cretaceous of the Sioux City area as used by the U. S. Geological Survey and by the Iowa geologists. Calvin's generalized section of the Cretaceous rocks exposed in the bluffs facing Big Sioux river is 'given below : ${ }^{70}$

9. Calcareous beds consisting of chalk and soft, thin bedded limestone, containing shells of Inoceranus problematicus, Ostrea. congesta, and teeth of Otodus, Ptychodius and other selachians

8. Shales more or less unctuous to the feel, somewhat variable in color and texture, containing remains of saurians and teleost fishes, the upper beds sometimes bearing impressions of Inocor

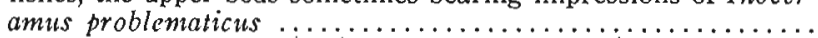

7. Argillo-calcareous or arenaceo-calcareous beds with much sele-

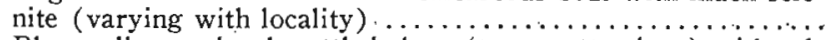

6. Blue, yellow and red mottled clays (terra cotta clays) with selenite crystals and some streaks of sand $\ldots \ldots \ldots \ldots \ldots \ldots \ldots$

5 enite crystals and some streaks of sand $\ldots \ldots \ldots \ldots \ldots \ldots, 30 \mathrm{Ft}$.

4. Shales with usually two, but sometimes more, well-marked thin bands of ferruginous concretionary sandstone ("Buttons" of the

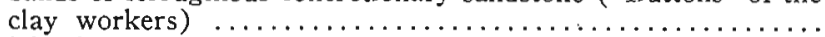

3. Massive sandstone, mostly soft; but in places containing large concretionary masses several feet in diameter in appearance and hardness resembling quartzite $\ldots \ldots \ldots \ldots \ldots \ldots \ldots \ldots$

2. Grayish and mottled shales with thin ferruginous bands and

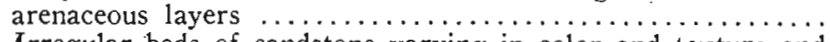

1. Irregular beds of sandstone varying in color and texture and interstratified with thin beds of shale $\ldots \ldots \ldots \ldots \ldots \ldots \ldots$

$30 \mathrm{Ft}$.

40 .Ft.

$20 \mathrm{Ft}$.

$16 \mathrm{Ft}$.

$10 \mathrm{Ft}$.

$12 \mathrm{Ft}$.

18. $\mathrm{F}_{\mathrm{t}_{1}}$

The section as given totals 176 feet, the upper 70 feet being youriger than Dakota. Calvin ${ }^{71}$ states: "Beds 1 to 7 inclusive are the strati-

\footnotetext{
68 Idem, p. 14.

60 Calvin, S., Iowa Acad. Sci. Proc., Vol. I, part iii, pp. 7-12, 1893.

70 Idem, p. 8.
} 
graphical equivalents of beds near Ponca, Nebraska, which Hayden refers to the Dakota group. No. 8 includes beds that at Ponca and St. Helena have been referred to the Fort Benton group by the same author, and the Inoceramus beds No. 9, are the exact equivalents of the lower twenty or thirty feet of the Niobrara group." Calvin discusses the conditions of deposition of the Cretaceous and concludes that northwestern Iowa was near the shore line of a slowly advancing sea that came from the west. The differences in the character of the beds at Sioux City which Calvin called Niobrara and the beds of the same age at the type locality 85 miles west are due, he thought, to the differences in the position of the shore line. The differences in the lithology of the Dakota are explained in a similar way: "The sandstones and shales of the Dakota group, with respect to the lower portions at least, were accumulated in a rather shallow land locked sea. Currents swept the sand back and forth, sometimes building up, and again tearing down, previously constructed beds, and so produced the fine examples of cross bedding or current structure"; and: "The few molluscan species found in the lower part of the Dakota group indicate the presence of brackish water. The numerous vegetable remains which characterize the group imply that the large volumes of drainage waters which maintained the conditions favorable to the existence of brackish water mollusks, carried not only sand but. swept in leaves and trunks of the willow. poplar, magnolia, and other forest trees, from the adjacent lands." 22 The Fort Benton group merely represents a deep or open water sea that developed by a slowly subsiding ocean basin from the conditions described for the Dakota. These interpretations aid Calviri ${ }^{73}$ to conclude "that the question of dividing the sediments into distinct groups at all is simply one of convenience" and as "the upper portions of the Dakota merge gradually into the Fort Benton" such divisions, if made, must be purely arbitrary.

Calvin ${ }^{74}$ expresses a law which is now generally well understood, though sometimes neglected, that: "Synchronous deposits of the same geologic basin are more likely to present uniform lithological and paleontological characters, if the geologist traces them along a line parallel to the shore of the basin. If the observations are made along the line that is radial to the geologic basin, or at right angles to the trend of the shore, the different parts of absolutely synchronous beds are almost certain to vary in lithological and paleontological characteristics, so much as sometimes to make it appear that different parts of the same bed belong to different geologic epochs."

72 Calvin, S., op. cit., p. 11.

73 Idem, pp. $11-12$.
74 Idem, p. 12 . 
Hicks $^{\mathbf{7 5}}$ reported in 1885 the finding of a new locality of Dakota marine invertebrates in southern Nebraska and discussed the "beach structure" of the sandstone. Later he described this locality in "Jefferson county, Nebraska, 5 miles west of north from Fairbury, about 1 mile from the Little Blue river - - - upon the north side of a deep ravine about halfway up the slope. This ravine runs into Whiskey Run, and the latter empties into Little Blue river". ${ }^{78}$ White made a study of Hicks' collection and decided the mollusks to be fresh water types. In general, White is skeptical of any marine Dakota, tending to believe at that time that the collections of marine invertebrates from central Kansas, as reported by Mudge, belong to a lower formation, and doubting if the evidence of two or three marine forms from the Dakota of the Big Sioux river area is sufficient to warrant the conclusion that marine conditions existed at that place.

White identified and figured the following species:

Unio barbouri n. sp.

Unio sp.?

Corbula hicksii n. sp.

Goniobasis jeffersonensis n. sp.

Goniobasis sp.

Pyrgulifera meekii n. sp.

Viviparus hicksii n. sp.

Keyes ${ }^{77}$ Calvin $^{78}$ and Bain ${ }^{79} 80$ published articles on the Cretaceous of Iowa in the 1890's. Most of this material is a repetition of the articles that have been reviewed, and very little new was added. Keyes called the Fort Dodge gypsum beds Cretaceous, believing they were deposited at the same time as the Niobrara chalks along Missouri river. ${ }^{81}$

Bartsch $^{82}$ lists 16 species of leaves from a ferruginous sandstone lens of a shale formation exposed just north of Sergeant Bluff. He suggests that the autumn winds would blow leaves from the upland or intermarsh trees into the marshes, lagoons, bayous and other submerged areas, where the leaves were covered under the sediment of sand and silt brought in by the fall rains.

In 1900 Gould $^{83}$ published an extensive review of the Dakota of Kansas and Nebraska. He gives a good historical sketch of the de-

\footnotetext{
78 Hicks, Proc. Anier. Assoc. Adv. Sci., Vol. 34, pp. 217.219, 1885.

76 White, U. S., Natl. Mus. Proc., Vol. 17, pp. 131-138, 1894.

77 Keyes, C. R., Iowa Geol. Survey, Vol. I, pp: 123-128, 1893.

78 Calvin, S., Iowa Geol. Survey, Vol. I, pp. 147-161, 1893.

78 Bain, H. F., Iowa Geol. Survey, Vol. III, pp. 99-114, 1895.

so Bain, H. F., Yowa Geol. Survey, Vol. V, pp. $241.299,1896$.

\$1 Keyes, op. cit., p. 137.

32 Bartsch, P., Bull. Lab. Nat. Hist. S. U. I., Vol. 3, No. 4, p. 178, 1896.

99 Gould, C. N., Kans. Acad. Sci. Trans., Vol. 17, pp. 122-178, 1901.
} 
velopment of the studies on the Dakota and a good bibliography. His references to the type area of the Dakota formation include a review of the literature which has already been discussed in this paper and a very generalized section which he compiled from his own observations and the published sections. Gould finds difficulty in determining the lower limits of the Dakota, as he recognizes the condition in central Kansas where the "Dakota flora" occurs beneath the marine Mentor of Washita age. The top of the Dakota formation is indefinite and indicates a transition to the Benton formation: Gould is "reluctantly forced to the conclusion that any persistent or general division of the Dakota group is not only impracticable, but, in the light of our present knowledge, impossible." 84 As to the origin of the deposits, Gould does not offer any new suggestion but concurs with Lesquereux, whom he quotes as considering the Dakota as a series of deposits made in shallow water near the strand line, and often with the land deposits pushing out into the sea. The flora, according to Lesquereux, ${ }^{85}$ has been "derived from trees or groups of trees growing in the vicinity of muddy bottoms, where they have been buried and fossilized."

Gould ${ }^{86}$ gave a very general description in 1900 of the Dakota formation of Nebraska, but. without adding materially to what was already known. The best part of this paper is his statement of the location of the various types of Dakota in the state. A year later ${ }^{87}$ he gave a comparison between the Nebraska and Kansas Dakota and again cited locations and gave some good sections. Very little of the type section is discussed in this paper. However, this is one of the first publications giving a detailed description and correlation of the Dakota formation from Nebraska to Kansas.

The first general geological study made of Dakota county, Nebraska, was published in 1903 by Burchard. ${ }^{88}$ In this report Burchard reviews the work of previous geologists, gives records of deep wells, gives several new sections, especially near Homer, Nebraska, and gives a detailed account of the lignite beds. No new conclusions are reached concerning the history of the sediments, as his interpretations are essentially the same as those made by Calvin. ${ }^{89}$ Burchard places the division between the Dakota and the Graneros at the base of the Ben-

84 Idem, p. 144.

86 Gould, C. N., Am. Jour. Sci, Ser. 4, Vol. 9, pp. 429-433, 1900.

86 Gould, C. N., Am. Jout. Sci, Ser. 4, Vol. 9, pp. 429-433, 1900.1

87 Gould, C. N., Kansas Acad. Sci. Trans., Vol. 17, pp. 122-178, 1901,

80 Calvin, Iowa Acad. Sci. Proc., Vol, I, part iit, pp. 7-12, 1893. 
ton, "at the upper plant bearing sandstone member of the Dakota."90

In the comprehensive report by Darton $^{91}$ published in 1905 are found the sections and localities of the Dakota formation of Nebraska, much as in previous reports by other authors. Darton emphasizes the irregular contact of the Dakota on the Carboniferous limestones as observed in the southeastern part of the state and infers a marine origin for the Dakota. He says" "the contact line between the Dakota sandstone and the Carboniferous beds in eastern Nebraska presents many steep slopes, indicating an irregular shore line against which Dakota sediments were deposited." However, in speaking of the coarse conglomerates and 'peanut gravels' near Cedar Creek, Darton ${ }^{93}$ suggests they are "probably marking old stream courses in the Dakota deposition." The general irregularity at the base of the Dakota (and in Nebraska it is in contact with Pennsylvanian or Permian limestones and calcareous shales) becomes obvious when the thickness of the Dakota type of sandstone is observed in the many deep wells of the state. The thickness of the Dakota ranges from less than one hundred feet to about four hundred feet.

In Water Supply Paper 215 Condra $^{94}$ describes the Dakota sandstone of northeastern Nebraska and gives several sections of the formation in the type area. He notes the irregular thickness of the formation indicated in the deep wells of the area. One point which he makes that is worthy of note here is his statement that "the component beds of the Dakota formation in this region are not sufficiently continuous, extensive, nor distinctive to afford a basis for subdividing the formation into different horizons."9s

In his description of the geology of the Elk Point quadrangle Todd ${ }^{86}$ uses the previously described sections of the Sioux City and Dakota county areas in his discussion of the Dakota sandstone.

Darton $^{87}$ does not discuss the type section of the Dakota formation in his water supply paper on South Dakota. He gives a number of well records which mention the thickness of the formation in adjacent localities and indicate the extreme variability of the sandstone. A point

90 Burchard, Idem, p. 150

01 Darton, N. H., U. S. Geol. Surv. Prof. Paper 32, pp. 140-144, 1905.

92 Idem, p. 140.

24 Condra, G. E., U. S. Geol. Survey Water Supply Paper 215, 57 pp., 1908.

96 Tod, U. 9 . S. Geologic Atlas, Folio No. 156, 1908.

96 Todd, U. S. Geologic Atlas, Folio No. 156, 1908.
07 Darton, N. H., U. S. Geol. Surv. W. S. Paper $227,1909$. 
of interest is the statement that wells drilled at Yankton, South Dakota, pass from the Dakota formation into Sioux quartzite. ${ }^{88}$

From 1910 to the present many papers have appeared by various authors, who have discussed the Dakota sandstone formation of localities in the central interior of the United States. Practically all of these writers have made brief references to the type area of the Dakota formation, without adding to the detailed knowledge or interpretation of the sections. In many cases, however, the interpretations made by the various writers for the Dakota formation in other regions have been helpful in the study at the type locality. For this reason brief mention of such contributions is made here.

Todd $^{99}$ reviewed the literature concerning the age of the Dakota stage and reached the conclusion that it is Lower Cretaceous in age. Much of the question as to the age of the Dakota stage arises from studies of the beds in localities other than the type area.

The relationships of the Dakota stage in the Black Hills, in Kansas, in Colorado and other places show that the problem is not simple. It might be said here that this difficulty has arisen from an effort to correlate over too wide an area a sandstone and shale series lying beneath the chalk beds. The paleophysiographical conditions of the interior and the older sea and land deposits varied so greatly that the Dakota overlapped beds of widely different ages or in some cases was nearly continuous with only slightly older deposits. The resulting variations of environment and modes of deposition of the Dakota stage complicate the problem. The question of the real age of the Dakota stage in the many localities is still unsolved, as it was when Todd considered the subject. Unfortunately, Todd failed to clarify the problem, as he denied the possibility of the Dakota stage being of different ages in different localities. To indicate his stand, the following quotations from his summary should suffice $:^{100}$

"From the standpoint of stratigraphy, it is questionable whether much, if any, of the present Dakota sandstone was laid down contemporaneously with any of the marine Upper Cretaceous. No doubt there were terrestrial deposits laid down over the Great Plains, while marine beds, now recognized as Upper Cretaceous, were forming in southern Texas or Mexico; but in the later transgression of the sea northward several feet in thickness of such beds must have been cut

98 Idem, p. 146.

90 Todd, f. E., Kansas Acad. Sci. Trans., Vols. 23 and 24, pp. 65-69, 1911.

100 Idem, pp. $68-69$. 
away by the wave action and rearranged in the Benton of the Upper Cretaceous, as Grabau argues. This may have removed all which was formed on the land during such transgression, and should it ever be found to be otherwise, still the rational and most convenient place of division would be above the Dakota.

The invertebrate remains of the Dakota are closely akin to those counted Lower Cretaceous, and are quite distinct from those of the Upper Cretaceous. The plant life, also, though less decisive, is in part at least coördinate with that of the beds below rather than with that of those above. The paleontological evidence, therefore, favors the same division as the stratigraphical.

Lithologically, also, the most natural classification will be to put the whole of the Dakota, as originally limited in the Lower Cretaceous. To divide it in most cases brings greater confusion. The division between the Dakota and Benton is not very sharply defined, for it takes a few scores of feet to change from a decidedly sandy formation to one decidedly clayey, several variable thin strata of sand and shale being intermingled between. As it marks the advent of the sea, however, the occurrence of marine fossils assists in the demarkation."

These statements summarize Todd's reasons for placing the Dakota in the Lower Cretaceous.

In a short abstract published in 1913 , Keyes $^{101}$ gives a new nomenclature for the 'Cretacic' sequence of Iowa. Seven zones are made of the approximately 800 feet of strata, beginning at the top; Niobrara limestone, Hawarden shales, Crill limestone, Woodbury shales, Ponca sandstone, Sergeant shales, and Nishnabotna shales. This section has not been adopted by the Iowa or other geologists, as the names merely duplicate the formations named by Meek and Hayden or do not have stratigraphic value.

Twenhofel ${ }^{102,}{ }^{103}$ has made extensive studies of the Dakota and Comanchean formations of Kansas, bringing to date the previous work on the Comanchean, and making a significant contribution to the paleontological knowledge of the Comanchean. Twenhofel is strongly of the opinion that the 'Dakota' belongs to a series of sands and clays that were deposited as deltas, stream channel deposits, and possibly in littoral or marginal lagoons, and that 'parts of the 'Dakota' sandstone of Kansas and the marine strata known as the Kiowa-Mentor

101 Keyes, Science, N. S., Vol. 38, p. 241, 1913.

102 Twenhofel, W. H., Kansas Acad. Sci. Trans., Vol. 28, pp. 213-233, 1917.

108 Trenhofel, W. H., Am. Jour. Sci., Ser. 4, Vol. 49, pp. 281-297, 1920 . See also Kans. Geol. Surv., Bul1, 9, 135 pp., ills., 1924. 
were deposited during the same general interval of time, the former being the continental equivalent of the latter."104

In describing the Mentor-Dakota sequence Twenhofel ${ }^{105}$ notes that the several marine horizons of the southern part of Kansas drop out northward, "but at least one marine horizon extends as far north as southeastern South Dakota." In making reference to the Dakota of the type area Twenhof $\mathrm{el}^{106}$ takes the statement of Meek that the Dakota formation is about 400 feet thick, and further states: "From some horizon or horizons of this sequence have been collected the following invertebrates: Arcopagella? macrodonta Meek, Cyrena dakotensis Meek, Mactra siouxensis Meek, Margaritana nebraskensis Meek, Pharella dakotensis Meek, Trigonarca siouxensis Meek. The zone containing the fossils correlates best with the thin sand layers in the upper Dakota of Kansas. The shells may have been inhabitants of brackish water, but not fresh water, as nearly related forms occur in the marine Mentor."

The difficulties of drawing the base of the Upper Cretaceous on the basis of the observations in Kansas and elsewhere are readily appreciated by Twenhofel. If the Cretaceous beds of North America are to be divided into Lower, or Comanchean, and Upper, where should the line be drawn? Twenhofel believes the line should be drawn, so far as Kansas is concerned, between the last appearance of the Washita fauna and the first appearance of the Benton fauna. ${ }^{107}$ According to his interpretation this would place the Dakota of Kansas in the Lower Cretaceous. At the same time he recognizes the prevalent opinion, held by some American and European geologists, which regards the Washita as the equivalent of the Cenomanian of the Upper Cretaceous of Europe. Even though Twenhofel bases his separation of Lower and Upper Cretaceous in Kansas on what he believes to be an extensive withdrawal of the sea at the close of Washita time, he realizes this might mean a difference in the exact age for the Washita as compared with the formations separated by a marine withdrawal in Europe.

Berry ${ }^{108}$ challenges the statements made by Twenhofe ${ }^{109}$ in placing the boundary between the Lower Cretaceous, or Comanchean, and the Upper Cretaceous at the top of the Dakota or the base of the Benton of Kansas. Berry calls attention to the errors which have arisen from

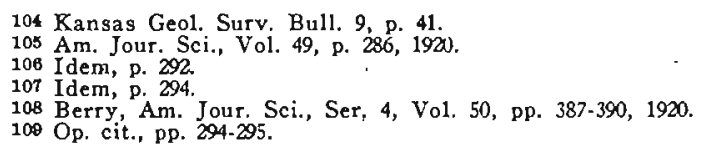


the confusion about the so-called "Dakota flora." The early collections were made from ferruginous sandstones in Nebraska, Kansas, Oklahoma, Colorado and other states and merely labelled "Dakota sandstone," without notes concerning the stratigraphic position of the sandstone or any of the usual details accompanying a fossil collection. According to Berry, this has caused a large number of species to be included in the "Dakota flora" which in reality come from horizons lower, and in some cases much older, than the true Dakota. One notable example is the Cheyenne sandstone of southern Kansas and the sandstones bearing dicotyledonous leaves below the marine Mentor of central Kansas. Berry bases the "true Dakota" flora on the flora of the Woodbine formation of Texas and corresponding ages elsewhere. $^{110}$ The Woodbine flora, he says, is intimately associated with the Benton transgression, while the Cheyenne flora has nothing in common with the "true Dakota" flora. No reference is made to the flora from the sandstones of the Dakota type area.

The same author ${ }^{111}$ mentions the typical Dakota in his paper on the flora of the Cheyenne sandstone. He comments: "As originally understood the term Dakota was applied to the pre-Benton Cretaceous, no Lower Cretaceous being recognized in that region. Unquestionably the typical Dakota sandstone represents the littoral or marginal deposits of the transgressing Benton sea - - -."

Stanton ${ }^{112}$ recently brought to the attention of geological workers the status of the various problems connected with the Dakota sandstone. It is obvious that the problems have only been scratched on the surface and that much work remains to be done. As this is a general paper, only brief references are made to the type section, but because of the prominence of this paper, a more complete review will be made.

Several lists of fossils collected and identified by Stanton appear for the first time, and for comparative purposes later they are given here. From a locality discovered by Gould near Jackson, Nebraska, the following forms have been recognized $:^{113}$

Ostrea sp.

Trigonarca siouxensis Hall and Meek

Arcopagella? macrodonta Meek?

*Pharella?

Corbula hicksii White

Martesia? sp. Casts of burrows in wood

Pseudomelania ? sp.

110 Berry, op. cit., p. 387

111 Berry, E. W., U. S. Geol. Surv. Prof. Paper 129, pp. 199.231, 1922.

112 Stanton, T. W., Geol. Soc. America Bull., Vol. 23, pp. 255-272, 1922. 
*Vivipara hicksii White ?

Volutoderma ? sp.

Vertebra of fish

Vertebra of turtle

Tooth of crocodile

Stanton comments that most of these forms indicate marine waters (except those marked *, which may be either fresh or brackish water) and that the sediments indicate a struggle between sea and land along a low sandy shore with swamps, lagoons and inlets.

From a locality near Beloit and Denmark, Kansas, Stanton ${ }^{114}$ collected and identified the following species:

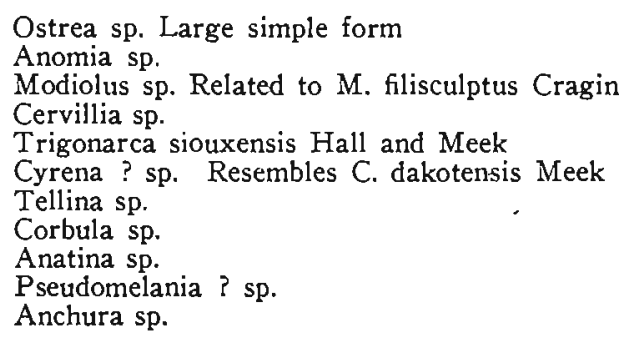

From approximately the same horizon in a coal mine shaft two miles north of Denmark, Kansas, the following forms were collected $:^{115}$

Ostrea sp. Small simple form

Anomia sp.

Modiolus sp. Related to M. filisculptus Cragin

Arca sp.

Anatina sp. Same as at Beloit

Commenting on the last two collections, Stanton states: "These fossils show no closer relationships with the Mentor and other upper Comanche faunas than is indicated by the presence of some genera in common. The specific identities all connect it with the upper Dakota fauna of Nebraska."

After reviewing the evidence of the Texas, Colorado, Black Hills and other sections, Stanton ${ }^{110}$ concludes: "The encroachment of the sea on the American continent which inaugurated Trinity (earliest Comanche) time was gradually continued throughout Trinity and Fredericksburg time, but at the beginning of the Washita the movement was accelerated without previous reversal and the sea soon reached Kansas and Colorado." Rather than a complete withdrawal of the sea to Texas at the close of Mentor time in Kansas, as suggested by Twenhofel, ${ }^{117}$ Stanton believes that the sea merely halted for a time,

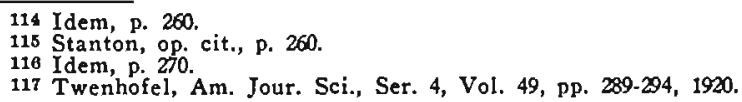


during which the Dakota was deposited. Because of the conditions in northern Colorado and the Black Hills, Stanton does not believe the Washita sea extended beyond southern Colorado and central Kansas.

Reeside $^{118}$ described a small fauna from rocks correlated as Dakota, near Bellvue, Colorado. and adjacent localities. This fauna he believes to be "more like that of the Washita group than that of the succeeding Benton shale, or that of any known Dakota beds, and a correlation based on the faunas must be a correlation with the Washita rather than with the Benton."110 The fauna is small and lacks some of the most characteristic of the Washita-Kiowa-Mentor species, but it is true that the presence of Inoceramus comancheanus Cragin, Pteria salinensis White, and Anchura kiowana Cragin certainly have a KiowaMentor aspect. The large amount of fish scales and bone material in the collection is more indicative of later Cretaceous or Benton age. Reeside also notes that in Kansas the Washita and Dakota beds are so intimately related that any great difference in age is impossible.

The most extensive contribution to Cretaceous stratigraphy in recent years has been made hy Lee. ${ }^{120}$ After years of detailed study of sections throughout the western interior and the Rocky Mountain states, Lee was able to make correlations and suggestions concerning the conditions of deposition of sediments which have been puzzling geologists for a long time. Lee stresses the importance of structural relations and believes they are of much more significance than fossils in separating the rocks into systems and series.

Lee uses the name "Dakota group" for the section along the Rocky Mountains, especially at Bellvue, Colorado, and he believes "these rocks form a group, as that term is used both popularly and technically."121 $\mathrm{He}$ recognizes the presence of rocks of both Upper and Lower Cretaceous ages as classified by the U. S. Geological Survey. His belief is best understood by quoting his repetition of his statement made in 1923. ${ }^{122}$

"There is no single, definite, persistent, and easily recognized sandstone, such as was formerly supposed to exist and was termed the Dakota sandstone. In its place there is a group of intimately related beds, probably even more complicated than the

118 Reeside, U. S. Geol. Surv. Prof. Paper 131, pp. 199-208, 1923.

119 Idem, p. 200

120 Lee, W. T., U. S. Geol. Surv. Prof. Paper 149, 80 pp., 1927.

121 Idem, p. 25. 
correlation lines - - - indicate. Doubtless there are many overlapping lenses that differ slightly in age. The group as a whole is interpreted as the result of accumulation of sediments near the strand line of the advancing sea, and as such it differs in age from place to place by the length of time consumed by the advance of the strand line across the intervening distance."

On another page Lee ${ }^{123}$ discusses the general conditions which prevailed at each stage and emphasizes his belief that the Morrison formation of Colorado is Lower Cretaceous in age and that Upper Cretaceous time began with the extensive sea invasion, with the deposition of the conglomerate which he has been able to trace throughout large areas. The variations in the Dakota group as he describes it are due to the slowness of the general advance of the Upper Cretaceous sea, with its many fluctuations and minor retreats. Rocks not strictly marine would be formed along the coastal plain or littoral zones, to be covered later by the oncoming sea. With this understanding Lee" "regards the group as the early sedimentary expression of the great marine Cretaceous succession of the West" but "does not correlate its individual beds from place to place with great exactness. - - - Nevertheless, a significant succession is recognizable in many places."

It might be added here that Lee has placed the Washita beds of Kansas in the Upper Cretaceous, partly because he correlated the Washita with the Cenomanian, a part of the Upper Cretaceous of Europe. It is 'generally recognized in this country that the WashitaKiowa rocks of Kansas are younger than the European Lower Cretaceous. In the same way, Lee includes the Purgatoire of southeastern Colorado in his "Dakota group." It seems very likely that Lee has given impetus to ideas that have been in the background for a long time and that once given the necessary complete study will aid in the solution of the Dakota problem.

Russell ${ }^{126}$ has made the most recent contribution to the general study of the Dakota sandstone. It is his opinion that the Dakota of the Black Hills is older than that of the type locality. He quotes Berry to the effect that the Newcastle member of the Mowry in the Black Hills carries a flora that is older than the type Dakota flora. ${ }^{126}$ Russell

\footnotetext{
123 Idem, p. 19.

126 Russell, W. L., Econ. Geol., Vol. 23, pp. 132-155, 1928.

126 Idem, p. 135 .
} 
Calvin, Keyes and others describe the occurrence of boulders containing Benton, Niobrara and younger Cretaceous fossils in the glacial drift of various parts of Jowa.

Considerable time has been spent in the field endeavoring to locate outcrops from which the "Mentor fauna boulder" might have been derived, but so far the search has been unsuccessful. 
concludes that the condition of deposition caused an overlap of the Dakota formation from the Black Hills eastward to northeast Nebraska and northwest Iowa and that the sediments were derived from the east. He uses the direction of inclination of foreset beds in the cross-bedded zones for the principal evidence. In the Black Hills, he says, the oblique lamination of the Lakota, Fuson and the so-called Dakota sandstones have a marked northwest dip, indicating a source of the sediments to the southeast. The thickening of the Graneros from 50 or 100 feet in northeast Nebraska to 1000 feet in the Black Hills is also used as evidence of the eastward migration of the shore-line. Russell is convinced that the Dakota is extremely lenticular, so much so that it could not be a good aquifer, and gives as one of his reasons that "most of the Dakota strata are of terrestrial origin."127 However, marine sands, possibly as littoral bars, barrier beaches and such, must have been common during this time, for Russell ${ }^{128}$ says that the upper Dakota beds "are formed as overlaps or oblique transitions along the shores of an advancing sea, and the topmost strata are much younger towards the east - -."

The discussion of Russell's paper by Piper ${ }^{129}$ sets right some facts. Piper is of the opinion that the Dakota sandstone lenses have fair continuity when understood in three dimensions. He points out the wide variety of environmental conditions of deposition, saying they "are river channel, river flood plain, tidal swamp, beach and shallow marine sediments transported by westward-flowing streams and deposited along and adjacent to a strand line which migrated progressively northward and eastward." 130

In December, 1926, the writer ${ }^{131}$ presented a short paper to the Paleontological Society at their Madison meeting, describing the occurrence in the Kansan glacial till of western Iowa of cobbles of a red ferruginous sandstone containing a marine fauna of Mentor aspect. The physical character of the sandstone of these cobbles is very similar to that of zone 6a in Section 1 at Sioux City, described in the present paper. The Mentor fauna is also closely related to the invertebrates occurring in zone $6 \mathrm{a}$ of the section just mentioned. Similar erratics have not been reported previously, although many short papers by

\footnotetext{
127 Russell, op. cit., p. 151.

128 Idem, p. 151

129 Piper, Econ. Geol, Vol, 23, pp. 683-696, 1928.

181 Tester, Bull. Geol. Soc. Am., Vol. 38, p. 233, abs., 1927.
} 


\section{CHAPTER IV}

\section{THE USE OF ROCK TERMS FOR THE DAKOTA}

It is evident from the various quotations in the foregoing pages that confusion exists as to the kind of term which should be applied to the rocks which comprise the sandstones, shales and other types of rocks named Dakota by Meek and Hayden.

The original definition of the rocks as given by Meek and Hayden ${ }^{132}$ used the term Dakota group, a part of the "lower series" of the "Cretaceous formation." The "lower series" included the Dakota group, Fort Benton group and Niobrara division or group. The authors of the Missouri section do not define their understanding of the terms group, formation or series. It is apparent from their application that the term series denotes rocks of like paleontological characteristics, or at least rocks with a variable fossil content, but one distinctly different from the fossils of the overlying and underlying series. The term group apparently is used by $\mathrm{Meek}^{\mathbf{1 3 3}}$ to designate a sequence of rocks lithologically similar, or if dissimilar or of non-persistent zones, the sequence is distinct from the overlying and underlying group.

The term system of rocks or period of time is widely accepted and used, and there is no need to vary from the rule. To speak of the Lower Cretaceous Series, as used by the U. S. Geological Survey, would not be in accordance. with the method of applying geographic terms to rock divisions. The use of lower, middle and upper as applied to various systems is merely a convenience and does not justify the designation of the term series. A series of rocks might represent, in the writer's opinion, the lower and middle, or the early and middle parts of a system; or the early part of a system might be composed of more than one series.

The term group, however, is used in different. ways. The United States Geological Survey ${ }^{\mathbf{1 3 4}}$ uses the term to designate "several formations assembled into a group", and a formation is described as a division of a series, the series being a division of a system. The U. S. Geological Survey does not use the term group in the same sense as it

182 Meek and Hayden, Phil. Acad. Nat. Sci. Proc., Vol. 13, pp. 415-447, 1862; Meek, F. B., U. S. Geol. Surv. Terr., Vol. 9, p. 25, 1867.

134 Wilmarth, U. S. Geol. Surv. Bull., 769, p. 4, 1925. 
uses series, even though it may appear that the two are synonymous, from the fact that several formations may be grouped either as a series or as a group. The term group really means, in their usage, a sequence of formations of smaller magnitude than a series. By eliminating this overlap of words, either group or series could be freed and used for the rock equivalent of era. As considerable usage now demands the word group for the rocks of an era, it is logical that this change be accepted.

It seems desirable that a standard system be used for rock divisions. The binomial system now in use by many writers might be the most satisfactory. The literature is so thoroughly saturated with a variety of usages of some terms that many argue that it is impossible to change. To the writer this is one of the strongest arguments for the standardization of terms. The confusion made in the past does not justify such a continuation, and no time is better than the present for a correction. The usage of terms as applied to the Dakota sandstone is a strong example of the lack of standardization. The Meek and Hayden definition used the term group. Other writers have used series, stage, formation, and many merely used Dakota sandstone. The various terms that have been applied to the Dakota by a number of writers and state publications are indicated below.

Group

Meek and Hayden, U. S. G. S. and other articles, 1866-1876.

King, U. S. G. S. 40th parallel, Vol. I, pp. 298-300, 1878.

Calvin, Iowa Geol. Survey, Vol. I, p. 149, 1893.

Dana, Manual of Geology, p. 815, 1895.

Logan, Kansas Survey, Vol. II, p. 200, 1897.

Gould, Kansas Acad. Sci. Trans., Vol. 17, p. 123, 1900.

Le Conte, Elements of Geology, 5th ed., p. 491, 1903. Uses Dakota Group and Dakota Epoch.

Lee, U. S. G. S. Prof. Paper 149, p. 25, 1927.

Series

Grabau, Textbook of Geology, Vol. II, p. 686, 1921.

Stage

Bain, Iowa Survey, Vol. V, p. 255, 1896.

Bain, Iowa Survey, Vol. VIII, p. 328, 1898.

Scott, Introduction to Geology, p. 475, 1904.

Keyes, Iowa Survey, Vol. XXII, p. 344, 1912.

Formation

White, U. S. Nat'l Museum, V'ol. 17, p. 131, 1894.

Darton, U. S. G. S. Prof. Paper 32, pp. 165-169, 1905. 
Chamberlin and Salisbury, Textbook of Geology, Vol. III, p. 144, 1906.

Todd, Kans. Acad. Sci. Trans., Vol. 23, p. 68, 1909.

Lee, U. S. G. S. Bull 341, pp. 320-321, 1909.

Moore, Kansas Survey Bull. 6, p. 81, 1920.

Reeside, U. Ṡ. G. S. Prof. Paper 131, p. 199, 1923.

Schuchert, Textbook of Geology, Vol. II, p. 558, 1924.

Twenhofel, Kansas Survey, Bull. 9, 1924.

Rothrock, Oklahoma Survey, Bull. 34, p. 49, 1925.

Gould, Oklahoma Survey, Bull. 35, 1925.

Miller, Historical Geology, p. 270, 1928.

\section{Sandstone}

Berry, U. S. G. S. Prof. Paper 129, pp. 158 and 199, 1922.

And many others.

In addition many writers have used Dakota without any other term, speaking of it as 'the Dakota'. Some writers, while avoiding a rock term, mention the Dakota epoch. ${ }^{135}$

Lee ${ }^{136}$ recently described a section as the Dakota Group and says he "believes that these rocks form a group, as that term is used both popularly and technically." The writer presumes the technical use is in the sense of the U. S. Geological Survey usage, or as several formations, and probably as a subseries.

The lithology of the Dakota, the distribution of the various zones, the stratigraphic range and the interpretations made by the writer, all suggest that the term stage be used to designate the sandstones, shales and clays exposed near Dakota City, Nebraska, and described by Meek and Hayden as the Dakota Group.

Geologic events which are of considerable magnitude, and which - have some effect over a large area, or which constitute a normal progression of rocks, are considered responsible for the deposition of rocks comprising a stage. 'The widespread marine advance, with its shoreline variations due to minor retreats and advances of the waters and to the lands being built out into the ocean, or the migration of faunas and shifting of ocean currents, all have their effect on the character of the rocks. The rocks deposited under such conditions on an extensive scale, as they were during Dakota time, are classed as a stage. It might be said that a stage is indicative of a set of conditions of rock deposition rather than of a distinct lithological or paleontological division.

\footnotetext{
135 Hills, R. C., Elmoro folio (No. 58) U. S. Geol. Surv., 1899.

130 Lee, U. S. G. S. Prof. Paper, 149, p. 25, 1927.
} 
In this paper the term Dakota Stage for the rocks, or Dakota Age for the time, is used hereafter. It should be understood, then, that the writer does not conflict with the classification by Lee ${ }^{137}$ in the rank which the Dakota rocks hold in the aggregate of the Cretaceous section, but that he merely uses stage instead of group, since the latter term is better used as the rock equivalent of era. Thus a stage becomes a subseries or several formations so closely related that they should be held together and still kept as divisions of a series.

287 Op. cit., p. 25. 


\section{CHAPTER V}

\section{DESCRIPTION OF THE EXPOSURES IN THE TYPE AREA}

At the present time the finest exposures of the Dakota stage are to be found at Sioux City, Iowa, and its suburbs. This includes the Prospect Hill section, the exposures at the Sioux City Brick Company pits, the bluffs along Big Sioux river just south of the west entrance to Stone Park, and several other minor or small outcrops.

Other excellent sections can be observed at Sergeant Bluff, south of Sioux City; the old Crill Mill section about seven miles south of Westfield, Iowa, in section 32, township 91 north, range 48 west; the several sections in the vicinity of Homer, Nebraska; the Aowa creek exposures near Ponca, Nebraska; and many others, especially down Missouri river between Homer and Tekamah, Nebraska.

The section as exposed in the Sioux City Brick Company pits is given first as it can be studied readily. The face is fresh from frequent excavation and is typical of the formations of the Dakota stage. This section is complete, with the exception of the lowest clay members. The best invertebrate fossils collected by the writer came from this pit, and in addition it has yielded some excellent fossil leaves.

Section 1. Pits of the Sioux City Brick Company at Riverside, west part of Sionx City, Iowa, along the South Dakota branch of the C., M.. St. P. \& P. RR. East side section 23,T.89 N., R. $48 \mathrm{~W}$., Woodbury county; elevation of top of zone $6 a$ approximately 1125-1130 feet.

Top of section, glacial drift and loess

10 Limestone, chalky and argillaceous (marl-like), buff to gray color. Contains abundant Inoceramus, fish scales and microscopic Fotaminifera. Grades downward to a calcareous shale.

In thin sections the rock is extremely fine-grained, calcitic and kaolinitic. The Foraminifera show coarser calcite in outline and cavity fillings. Bands of limonitic iron oxide surround linear masses of fine calcite, the bands dividing and joining to give a cellular structure to parts

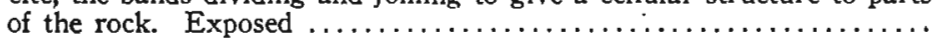

9 Sandstone, gray, medium- to fine-grained, dense, micaceous, and very firmly cemented by calcite. Contains large amount of organic material, chiefly fragments of fish scales, teeth and spines. Fragments of Inoceramus shells showing prismatic calcite are common, and numerous casts of small pelecypods (Callista?) are seen on weathered surfaces. Weathered rock is gray to buff in color and shows prominent thin lamination with cross-bedding and ripple marks.

The thin section examination shows the high percentage of calcite present as a cement and the abundance of glauconite. Other constituents include sericite, grains of quartzite, pyrite, zircon, basic feldspars, tour- 


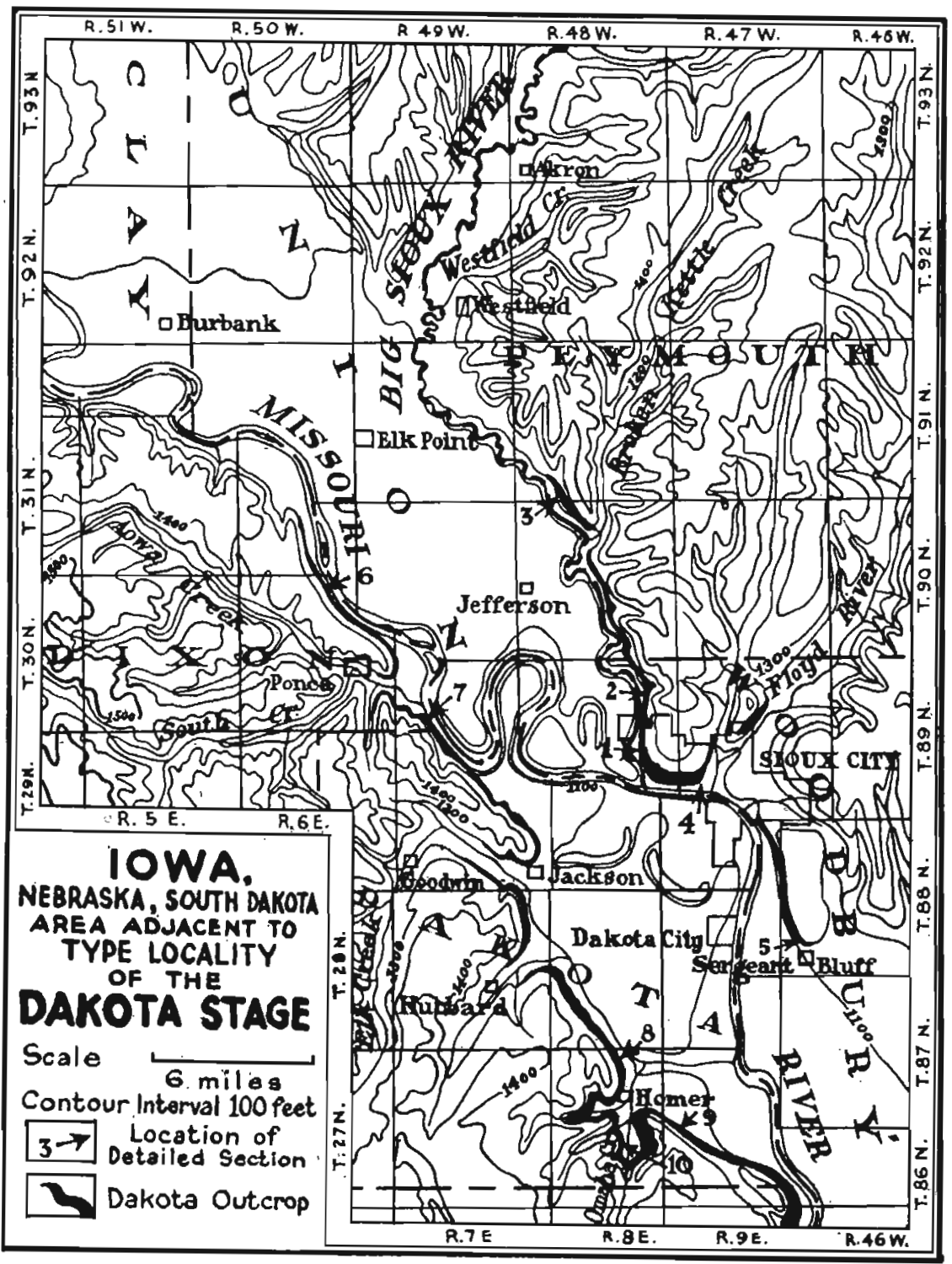

Fig. 25.-Map of the area adjacent to the type locality of the Dakota stage. Modified after Todd.

ZONE

FEET

maline and hornblende. About 60 per cent of the grains are angular, 30 per cent subangular, 5 per cent curvilinear, 5 per cent subround. In

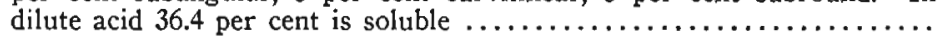
Photomicrograph, Plate III, Fig. G (Ts-07044).*

- Ts 07044 refers to thin section in the rock collection at the University of lowa. 
ZONE

FEET

8. Shale, argillaceous, blue-black, evenly bedded, but with many lenses of siltstone that are irregular and that show oscillation ripple marks. Glauconite in siltstone, and occasional fragments of fish scales and bones and imperfect pelecypod casts ..................................

7(b) Sandstone, buff-gray, well cemented by calcite, thin bedded and weathering in thin wavy plates exposing imperfect internal molds of small pelecypods

7 (a) Sandstone, gray, fine-grained, with many bands of large hard, dense calcareous concretions. Base of this zone is especially concretionary, with much iron oxide cementing the sand and lignitized wood ..............

6(c) Shale, gray, thin laminz, much selenite and fragmental plant remains ..

6(b) Sandstone, yellow and gray, friable, with varying amounts of iron oxide. Very fine-grained; practically a siltstone. Laminæ cross-bedded and variable in thickness and extent. Much shale in thin wavy lenses. Gyp-

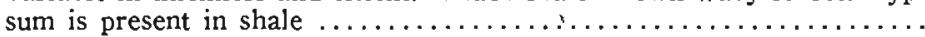

6(a) Sandstone, gray, buff to dark red, depending on character of cement. Normally it is cemented by calcite like zone 9 but iron oxide replaces the calcite and changes the character of the rock. The maroon, chocolate, brown, or yellow color of the iron cemented portion differs, depending upon the amount of weathering. Medium- to fine-grained, dense and resistant to erosion. This zone is fossiliferous and contains marine mollusks and abundant fragments of leaves and stems. In the calcitic phases the presence of the shells can scarcely be detected. Considerable secondary gypsum (selenite) occurs in small fractures and as replacements in shells. Pyrite is also commonly associated with the concretions. Glauconite is moderately abundant in this rock. 29.6 per cent of orig-

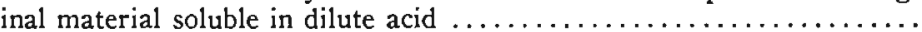
Photomicrograph Plate III, Figs. A, B, C, D, E, F, H, I.

Minerals: Glauconite (Biref .009-.010) R.I.-1.55 to 1.56, Zircon (some altered), Hornblende, Tourmaline, Mica (Muscovite), Magnetite, Ilmenite (rare), Leucoxene, Garnet (rare), Pyrite, Feldspars (several varieties, including a few very basic ones, and many highly weathered with development of kaolinite along cleavage planes), Chlorite (?) (probably secondary alterations product), Sillimanite, Quartzite (abundant), Iron oxide cement.

Slides of the calcitic phases show extensive alterations with iron replacing calcite with the development of pseudomorphs of hematite (?) after calcite. Also many of the feldspars show alteration with development of calcite.

Fossil List: Turritella kansasensis Meek, Margarita sp., Cardium n. sp., Corbicula (?) subtrigonalis Meek, Cyrena dakotensis Meek and Hayden, Mactra siouxtensis Meek and Hayden, Protocardia texana Conrad, Trigonarca salinaensis Meek, Trigonarca siouxensis (?) Hall and Meek, Fish bones, Leaf fragments, Cones.

5 Shale, dark blue-black, thin-bedded and fissile. Contains considerable selenite in small crystals and rosettes, all of which may be secondary. Locally some thin brown concretionary bands of arenaceous and clayey materials. Grades upward to sandstone with large amounts of selenite

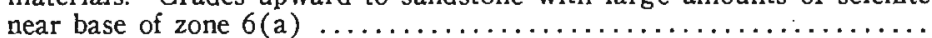

4 Sandstone, gray, very fine-grained, micaceous, has many minutely crossbedded zones 6 to 8 inches thick. The foresets of these zones have differing directions of inclination, though the easterly directions prevail; in order of numbers the direction of foresetting is, first, southeast, second east, third northeast, and least numerous to northwest. In the upper three feet (4b) are numerous thin variable and disconnected bands of impure lignite and fire clay, and much nodular pyrite. This material appears as very local fillings of depressions and vertical cracks or joints

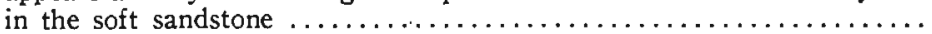

3.(c) Sandstone, buff, medium fine-grained, massive beds $\ldots \ldots \ldots \ldots \ldots \ldots$ 
3(b), Sandstone, gray, fine-grained with many thin wavy bands of gray clay. A few irregular concretionary zones .............................

3(a) Sandstone and siltstone, with bands of lignite, four being $1 / 8$ inch or

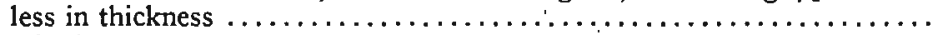

2 Lignite, poor grade, grading downward to impure fire clay. Thickness appears uniform throughout exposure except for irregular base with a variation of 2 or 3 inches. Sharp contact at top ...................

1 Shale, very argillaceous, gray to blue-black. Texture is variable horizontally. Some fine alternation of clay with silt and sand. The upper 4 to 6 feet is usually very free of sand, plastic or unctuous, massively

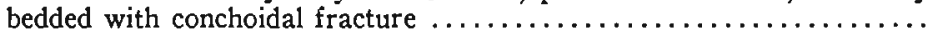

Total in section ....................................

In 1928 the lower pit exposing zone 1 was filled with water to within one foot of zone 2 , the lignite.

Zone number 10 belongs, without much question, to the Greenhorn formation as previously described. It is possible that zones 9 and 8 also are a part of the same formation, but there is very little change in lithology from the underlying sands of zone 7 . There is very little information to use as an exact basis of division between the Dakota and Colorado stages. Zone 8 shows small oscillation ripples and contains glauconite in the siltstone lenses. These two features are interpreted as indicators of shallow to moderately deep marine waters in a place which normally received deposits of mud; temporary shifts of shore currents or flood conditions of the feeding streams deposited a silt or fine sand. Apparently the conditions of deposition of zone 9 were very little different from those of the deposition of the siltstone layers in zone 8 . The age of zone 9 is more definite as it carries casts and fragmentary shells of characteristic Greenhorn invertebrates. Zone 7 , and the lower part of the section taken as a whole, is only slightly different from zones 8 or 9 , but when compared in detail the upper members indicate slightly more stable conditions. For example, the calcitic concretionary bands of $7 \mathrm{a}, 7 \mathrm{~b}$, and even $6 \mathrm{a}$, and the thin finegrained sandstone layers of 4 are all comparable to zone 9 . The interbedded shales and clays are in many cases nearly the same as the shale of zone 8, but a greater thickness of shale was accumulated with thin lenses of sand interfingering. Conditions were still unsteady, with shifting of currents near shores, but more stable than the conditions indicated by the lower part of the section.

Where then should the line be drawn separating the Dakota stage from the Graneros formation? In such a section, with apparent repetition of conditions, but at the same time with the introduction of new features or indications of gradual changes of environment, the 

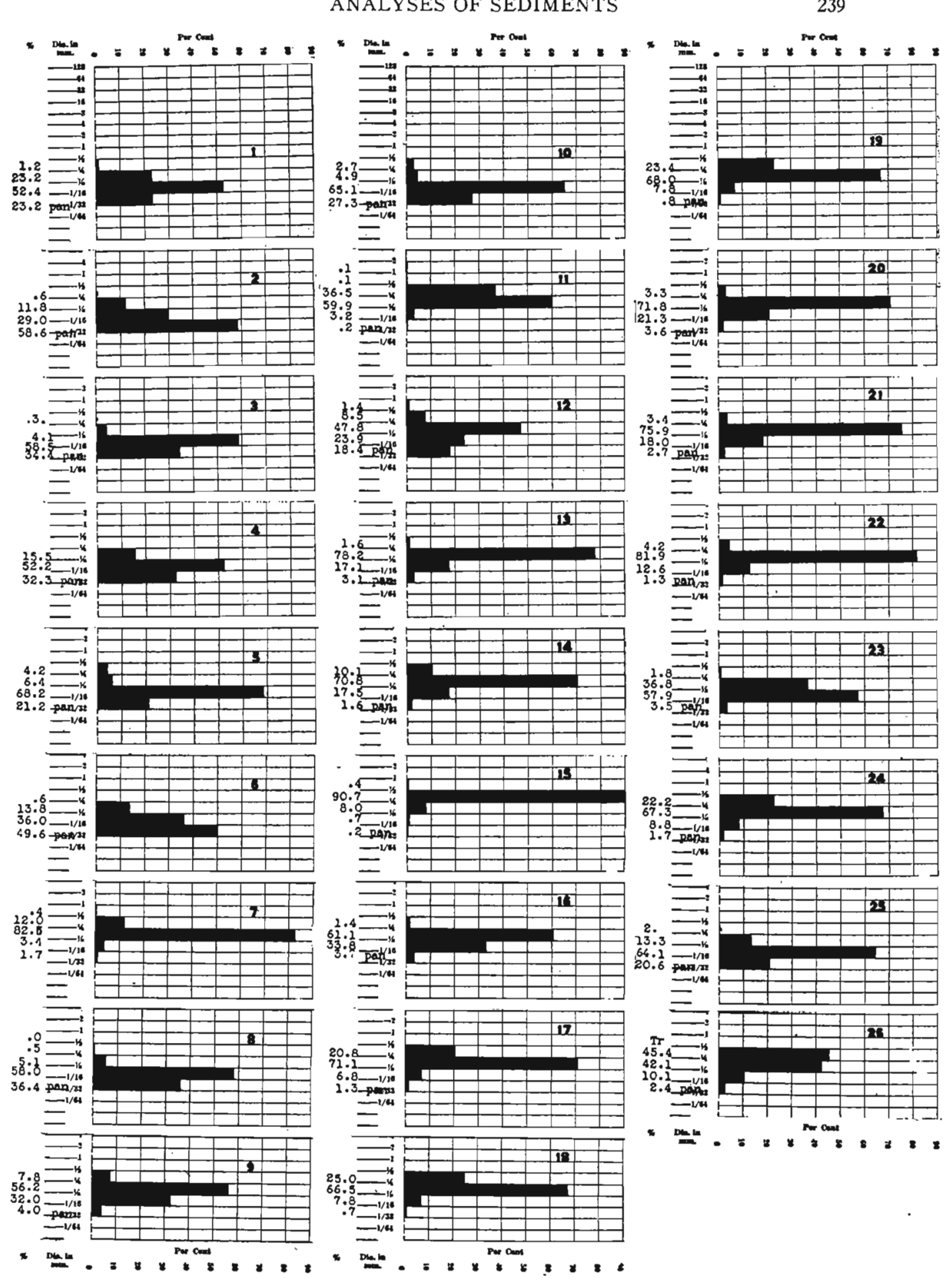

Figure 26 
writer believes that any division will be purely arbitrary and probably unsatisfactory. There appears to be a transition from the more typical Dakota of zones 3,4,5 and 6, to the typical Greenhorn of zone 10 . However, the best division, in the writer's opinion, between the Dakota and Graneros is to be found at the base of zone 8 .

Further comment on the character of the Dakota will be made after other sections in the area are described.

Section 2. Section 11, T. 89 N., R. 48 W., Woodbury county, Lowa, zest of Sioux City in the bluff facing Big Sioux miver at old quarry site south of west cnlrance to Stone Park. Elevation at normal zeter level approximately $1102 \mathrm{feet}$. color. Thin beds 2 to 10 inches thick interbedded with calcareous shale. Contain' much secondary calcite in fractures and joints. Inoceramus abundant. This is undoubtedly Greenhorn. Lower part is shaly and

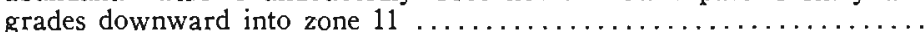

11 Sandstone and siltstone, gray to buff, fine-grained, iron oxide and clay cement.

Has very irregular bedding with wavy shaly bands. In upper part is a silt and more argillaceous and grades into zone 12 . In lower part of zone small cross-bedded zones are common with oscillation ripple marks and small mud cracks. Has much selenite in thin layers between wavy layers of siltstone. Erosion channels a few inches deep in thin alternating clay and sand layers are filled with well sorted sand. Sands and

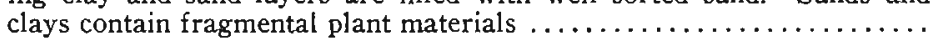

10 Shale, gray, carbonaceous, fissile, gypsiferous. No fossils observed ....

9 Sandstone, yellow to buff, very fine-grained, non-calcareous, chiefly clay binder. Micaceous, quartz sand with some gypsum, weathered amphi-

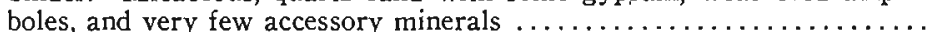

8 Shale, gray, carbonaceous, fissile, with selenite. Grades upward to a

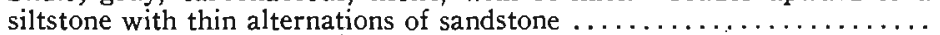

7 Sandstone, yellow to buff and gray, fine- to medium-grained, friable. Contains gypsum and some fresh sulphur; much clay as binder with varying amounts of iron oxide. Weathers as a massive bed, though a close inspection shows indistinct bedding planes and small cross-bedded zones. The top of the zone has a cap of red-brown fine-grained sand with a gnarly concretionary development which is more resistant to weathering and makes a prominent ledge 6 to 10 inches thick. This part of outcrop contains a small amount of greenish brown, partly decomposed glauconite. This may be the equivalent of zone $6 a$ of Section 1 .

Three feet below this ledge is a 3 -inch layer of impure lignite and clay with many fragments of leaves, stems and plant material. Contact with

FIG. 26.-MECHANICAL ANALYSES OF SEDIMENTS IN TYPE. AREA

No. 1. Section 1, zone 6a.
No. 2. Section 1, zone 6b.
No. 3. Section 1, zone 4a.
No. 4. Section 1, zone 4b.
No. 5. Section 1, zone 3b.
No. 6. Section 2, zone 2.
No. 7. Section 2, zone 4.
No. 8. Section 2, zone 5.
No. 9. Section 2, zone 9.
No. 10. Section 4, zone 1.
No. 11. Section 5, zone 10.
No. 12. Section 6, zone 1.
No. 13. Section 6, zone 2a.
No. 14. Section 7, zone 4.
No. 15. Section 8, composite.

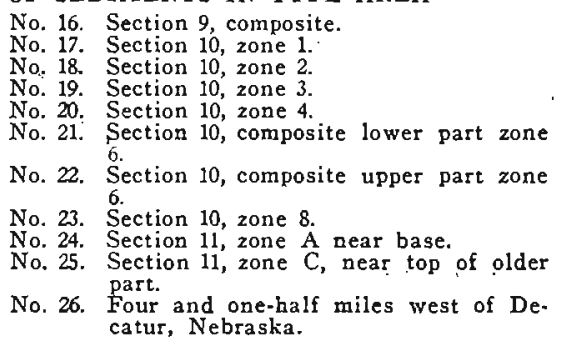


zone 6 uncertain but grades into shale with thin sandstone layers .....

Shale, with thin sandstone layers, and grading upward to sandstone of zone 7 . Where sand content is lower the shale is gray to black, carbonaceous and with fragmental plant material. Weathers fissile. In upper part contains considerable selenite and many pyrite concretions ... Sandstone, gray to buff, fine-grained, weathers as a single bed but in detail the generally horizontal laminæ show small northeast and northwest trending cross-bedded zones. Micaceous, abundant plant frag-

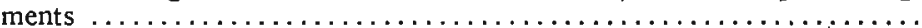

4 Sandstone and clay conglomerate, with fragments of lignite reworked into sand. The sand is medium- to fine-grained with small amount of clay binder. The clay pebbles range between 16 and $8 \mathrm{~mm}$. and are gray and thinly laminated and usually occur in a zone with a thin discontinuous clay layer. The clay pebbles were partly indurated when deposited. The contact with zone 3 is uncomformable in this section ..

3 Shale, gray turning to brown at lower contact. Carbonaceous and fis-

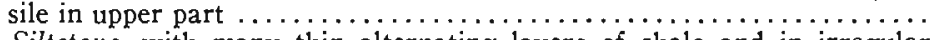

2 Siltstone, with many thin alternating layers of shale and in irregular zones. Siltstone is buff to brown, major grade smaller than $25 \mathrm{~mm}$. with a few grains nearly $1 / 2 \mathrm{~mm}$. diameter. Quartz is dominant but with a clay binder. Most grains yery angular, with appearance of fresh fracture chips. A few of larger grains show small amount of wear, falling in the subangular and curvilinear groups. The clay is iron stained when occurring as a binder and as thin laminæ is gray ........

1 Sandstone, with thin shale layers interbedded. Sand is gray, mediumto fine-grained. At top is a 1 - to $11 / 2$-foot zone of hard calcite- and hematite-cemented layer of concretions, more or less continuous. Where the sand is iron-oxide-cemented, glauconite appears more abundant, although it occurs throughout the section. Much carbonized plant material scattered throughout zone, especially in the concretionary masses .. Covered, slope, below road level but indicates an alternation of thin-

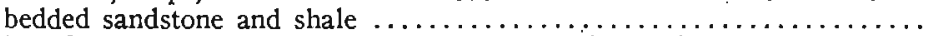
Big Sioux river level-elevation approximately $1,102 \mathrm{ft}$.

As in Section 1, the place of separation of the Dakota and Graneros is uncertain, but for similar reasons it is placed at the base of zone 8 . The sandstone of zone 11, Section 2, is thicker than the top sandstone of Section 1, but it has many of the same characteristics, and the stratigraphic relations with the overlying chalky or marly limestone are almost identical. In Section 2 the base of the Graneros is approximately 15 feet higher in elevation than in Section 1.

Section 3. Section 32, T. 91 N., R. $48 \mathrm{~W}$., Plymouth county. Road and river exposures facing Big Sioux river, near wagon bridge crossing about 7 miles south of Westfield, Iowa. This is probably the locality of the Crill Mill section of Bain.138

15 Limestone, buff to gray. Upper part thinly bedded, lower part soft and chalky and weathers like a buff shale. Contains many Inoceramus and small Foraminifera . . . . . . . . . . . . . . . . . . . . . . .

14 Shale, gray-black, carbonaceous, weathers fissile. Upper 4 to 5 feet is calcareous and grades into lower part of zone 15 . Very little sand in main part of zone. Contains small selenite crystals which are imbedded in fresh shale, making crystal impressions. Also some secon- 
dary gypsum developed along fracture and joint zones. The contact with zone 13 is fairly distinct, but the shale contains a good deal of sand. This probably is due to a certain amount of reworking of the top sandstone layer of zone 13. This is a typical Graneros shale ......

13 Sandstone, gray, fine-grained, with layers which are typical siltstones. Some thin iron oxide concretionary zones though major part of member is clay bound. Upper one foot is a prominent layer of mediumgrained friable yellow sandstone. Much dicotyledonous leaf material

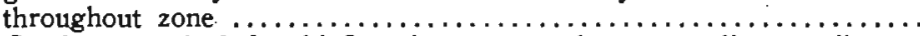

12 Sandstone and shale, chiefly micaceous sandstone, grading to siltstone in thin beds with interbedded even layers of shale $1 / 4$ to 1 inch thick. Near center of member a red and brown iron concretionary zone 6 to 8 inches thick makes a prominent outcrop. Some of these concretions are surrounded by more friable sands, and the glauconite is more abundant in the loose sands. Dicotyledonous leaves and fragments occur throughout. In local zones of member much carbonized wood and

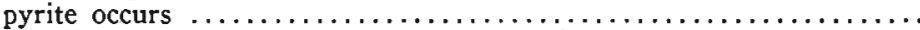
Photomicrograph, Plate III, Fig. J. (Ts-07045).

11 Shale and sandstone, interbedded, dominantly shale, gray in thin beds. Sandstone very fine-grained and similar to that of zone $10 \ldots \ldots \ldots . .$.

10 Siltstone, grades to fine-grained sandstone; gray to yellow ...........

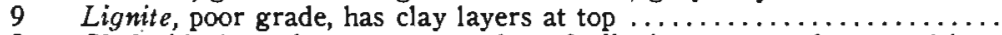

8 Shale, black, carbonaceous, weathers fissile, becomes sandy toward base with much fragmented plant material . ........................

7 Sandstone and siltstone, gray to buff, clay binder, many thin zones of concretions at base. Upper part has many lenses of siltstone with ir-

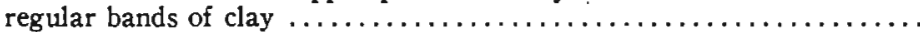

6 Sandstone, gray to yellow, fine-grained, micaceous, thin even beds. Iron oxide cement differs in amount, producing yellow and more resistant layers. Concretionary zone at base. Fragmental plant remains occur throughout, in laminæ $1 / 8$ inch apart . F......................

5 Sandstone, buff to brown, fine- to medium-grained, iron oxide and clay

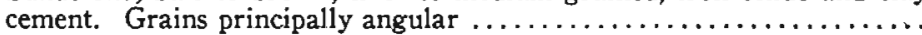

4 Sandstone and shale, largely a siltstone, interbedded in thin even layers. Much fragmental plant material and in silt or shale zones occasional

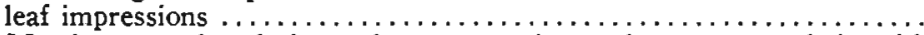

3 Mostly covered and slumped, except at base where a gray shale with small sandstone concretions may be seen .........................

2 Lignite, poor grade, cubic fracture. Contains pyrite nodules and car-

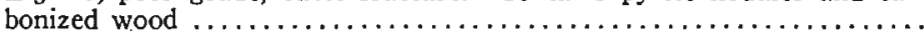

Shale, carbonaceous, grading upward into shaly lignite .................

The top of the Dakota stage in this section is placed at the base of zone 14. There is less difficulty in making the division between the Dakota and Colorado stages in this section than in any other outcrop in the Sioux City area. The lithologic change is more abrupt than is usually the case. Even with such appearance at the outcrop the base of the gray shale of zone 14 is somewhat sandy and indicates a certain amount of reworking of the sandstone layer at the top of zone 13.

Zone 12 probably is the equivalent of zone $6 \mathrm{a}$ of Section 1 . The lignite of zone 9 of this section occupies a stratigraphic position nearly the same as the lignite of zone 2, Section 1 , but the latter section has a larger thickness of sandstone and siltstone than Section 3. Section. 1 
probably was nearer the mouth of a distributary channel or in a more favorable position to accumulate littoral bars. Section 3, it appears, was more removed from the shore or in more quiet water for the major part of this period of sedimentation.

SeCTION 4. Sioux City, Iowa, one-eighth mile west of north end combination trolley and highway bridge across Missonri river and at foot of Prospect Hill. Elevation base zone 1 approximately 1,120 ft.

ZONE

FEET

5 Sandstone and siltstone, buff to yellow, thin wavy beds of paper thickness, gray clay interlaminated. Some discontinuous concretionary zones

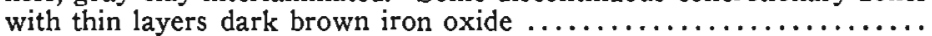

4 Sandstone, buff to yellow, very fine-grained, thin and wavy bedding. Lower part concretionary and contact with zone 3 irregular.

3 Siltstone and shale. This is a very irregular zone and is non-persistent within 100 feet of outcrop. Upper part chiefly siltstone grading coarser into overlying member 4. Lower part mainly shale and tough gray clay containing dicotyledonous leaves and much fragmented vegetable material. In central zone are many thin concretionary bands with concentrations of iron oxide in horizontal planes. Base unconformable with zone 2 with the development of iron concretions at contact ........

2 Sandstone, buff, fine-grained, grading to siltstone in upper part. Lower part more or less homogeneous. Base of member indistinct except as marked by poorly preserved oscillation ripple marks. Iron oxide is concentrated in thin zones $x / 8$ to $x / 4$ inch thick which are parallel to the

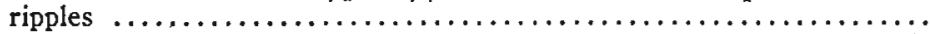

1 Sandstone, light gray to buff, fine-grained, micaceous, lower part in thin layers, upper part with numerous horizontal bands of brown-red con-

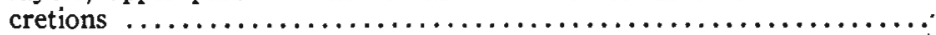

Section 4 probably is one of the classic exposures studied by Meek and Hayden, Marcou, Calvin, Bain and others who have made observations in the Sioux City area. Judging from descriptions by the early workers, this section was much better exposed 25 to 50 years ago than it is now. Years ago the main current of the Missouri was swinging against the bluff at this point, but due to the building of bars upstream the main channel cuts against the bank at the present time about 1000 feet downstream. Filling by man has aided in the building of a river flat between the present exposure and the river's edge. Slumping and the growth of brush has obscured a part of the old sandstone bluff as pictured by Bain. ${ }^{139}$ From this exposure some of the early collections of dicotyledonous leaves were made, and it is probable that most of them came from the lower part of zone 3 of the writer's section.

Attention should be called to the remarks concerning the iron oxide concentration which is very closely related to the ripple mark zones and minutely cross-laminated parts of the sandstone. In zones 1 and 5 truncation surfaces developed by wave or current action show a con-

199 Bain, Iowa Geol. Survey, Vol. VIII, p. 267, 1898. 
centration of iron oxide which penetrated a depth of only two or three grains, or which may be wavy and may cement the sand one-half to one inch below the old surface. In the case of ripple marks superposed on older ripples, with intervals varying from a fraction of an inch to two or three inches, a similar condition of concentration can be observed. The facts that such a concentration of iron oxide is usually restricted to the final ripple surface or a zone only a small fraction of an inch below it, and that such zones are repeated in some cases four or five times, and that the intervening sand is poorly cemented, indicate a cementation and concentration of iron oxide contemporaneous with or immediately following the formation of the ripples. Quoting from the writer's notes made in the field, in commenting on the interpretations possible from this section, the following statements are made:

"Zone 1. The unconformity at the top is again evidenced by a zone of poorly preserved oscillation ripple marks-trending slightly south of west.

In the lower 4 feet of the sandstone the beds are very thin and contain paper thicknesses of shale every one-eighth to one-fourth inch. Most of the laminæ contain fragmented plant remains, and carbonized wood occurs in some cases. This condition gradually changes upward as the sand is cleaner and is in thin even beds.

The zones of concretionary development and the hard ferruginous layers appear to be developed where a change of conditions of deposition occurred, or a short cessation of deposition, or a short exposure to conditions of consolidation, all of which may mean merely a short exposure with drying, cracking and oxidation of the surface or a zone one-fourth to three-fourths inch below the surface."

Approximately 600 feet west of the place where Section 4 was measured, zone 2 is only six feet thick and is capped in part by a zone of gnarly hard brown iron concretions, ranging from 8 to 20 inches in thickness. As the concretionary zone pinches out an irregular series of clay and siltstone takes its place.

Zones 1 and 2 probably are deposits made in a shallow gently shelving marine environment very near the shore. The ripple marks are small, having a wave length from crest to crest usually less than three.inches and an amplitude of about one-fourth of an inch and being nearly symmetrical. Large ripples with a wave length of tens of feet are sometimes found in shallow water but it is doubtful if small ripples like those described here are ever formed in deep water. The small 
unconformity at the top of zone 2 is possibly the result of wave or littoral current erosion, or of currents of nearby streams cutting out a part of the beach or littoral deposit. The writer believes the latter to be the better explanation as the succeeding deposits of zone 3 may be such a deposit, as is indicated by the following quotation from the writer's field notes :

"Just above the concretionary zone (at the unconformable contact with zone 2) the clay and silt is more or less sandy with a few layers of thin hard concretionary sandstone. Two feet higher is a tough gray clay with a conchoidal fracture for nearly six feet; then gradually the clay becomes sandy, until the upper three feet contains many irregular thin lenses of argillaceous sandstone and siltstone. The bedding is extremely irregular, with minute unconformities or diastems and paper thin layers of clay or shale. The conditions of deposition apparently were very irregular, with cut and fill, an occasional clay pebble as a concretion nucleus, and abrupt changes in texture. This is much as would be expected in a river deposit. Gradually these conditions give way to those of zone 4 which begins with a fine band rather evenly bedded and with thin yellow-brown layers which stand out in weathered exposures."

The dicotyledonous leaves are most abuindant in the clays and silts, but fragmented leaves, stems and carbonized wood are found in all parts of zone 3 .

Zones 4 and 5 are very similar to zones 1 and 2, the conditions of deposition being repeated after the accumulation of the fluviatile or deltaic deposits of zone 3 . The lower part of zone 4 indicates the reworking of zone 3 as the marine waters advanced.

Section 5. At Sergeant Bluff, Woodbury county, Iowa. Section 30, T. $88 N, R$. $47 \mathrm{~W}$, in pits of Ballou Brick Company.

15 Glacial sand, white to gray, well bedded

14 Conglomerate, pebbles of quartzite, chert, unconformable over zone 13. A Pleistocene deposit. Differing amounts of iron oxide cement .......

13 Sandstone, buff and yellow, medium- to fine-grained, friable. Many thin beds with concretionary developments and concentration of iron oxide along bedding planes. Dicotyledonous leaves common .............. Mineral Analysis: Glauconite rare and partly weathered, magnetite, black tourmaline, mica, chlorite and weathered feldspars.

12 Sandstone, red to buff, irregular iron oxide cementation. Where well cemented is resistant to erosion and often makes prominent ledges. Contains abundant glauconite and pyrite concretions. Where not cemented with iron oxide this zone is a typical calcitic sandstone and is similar

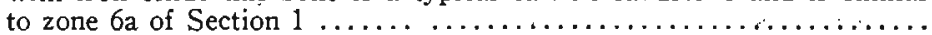

11 Sandstone and shale, gray to brown, with some thin iron concentration

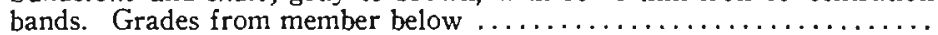


10 Sandstone, buff to yellow, medium-grained, friable. Usually in massive beds but with occasional thin clay partings. Cross-bedding with foresets inclined NW., NE. and N. Upper part more prominently crossbedded and shows numerous truncation planes and rippled surfaces with iron oxide as the cement. In lower 2 feet are found concretions

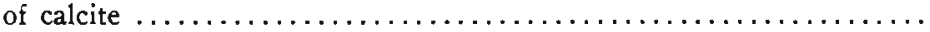
Mineral analysis: Muscovite common; magnetite, tourmaline, feldspars, zircon, amphibole, leucoxene.

The sand shows many moderately well rounded and curvilinear grains in the $1-1 / 2-\mathrm{mm}$. grade and many of them are frosted. The finer grains are angular to subangular.

9 Lignite, with some coal of fair quality. Grades to carbonaceous shale at base and is overlain by a gray plastic fire clay. Lignite is 13

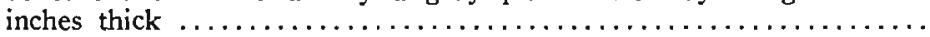

8 Clay, gray, unctuous, and with much fragmented plant material. In lower part are many small lenses of siltstone ....................

7 Siltstone, gray, clay binder, and occasional seams of carbonized wood ..

6 Shale, dark gray to black, carbonaceous, weathers fissile. Grades down-

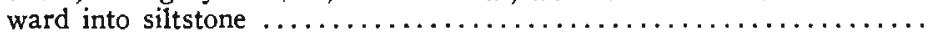

5 Shale, clay and siltstone, buff, yellow and gray. Thin-bedded and irregularly interlaminated. Grades from zone 6 without apparent division; contains much fragmented plant material and a few leaves. Best exposed in west shale pit ...................................

4 Sandstone, yellow, brown and red, fine- to medium-grained. Concretionary, is very resistant, appears like a quartzite. Where cemented with iron oxide color has some range; where cemented with calcite is brown with glassy appearance. The concretions do not make a continuous bed. Contains fish spines and glauconite $\ldots \ldots \ldots \ldots \ldots \ldots \ldots \ldots$

3 Clay, blue-black, buff, slightly gritty, some carbonized plant remains ...

2 Sandstone and shale, thin-bedded and grading to siltstone in many places, coarser at base .....................................

1 Clay, blue to gray; tough and compact, when dry like a dense limestone and breaks with conchoidal fracture. Locally contains some grit, and lime content differs with locality. Is splotched with iron oxide. Fx-

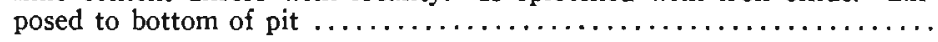

The entire section (other than the Pleistocene at the top) belongs to the Dakota stage, no Greenhorn occurring at this locality.'

Zone 12 appears to be the equivalent of zone $6 \mathrm{a}$ in Section 1 . The interval between zone 12 and the lignite of zone 9 is 30 feet while in Section 1 the interval is 23 to 24 feet. This may be due to an increase in thickness of the sediments deposited in the different locations, or perhaps the lignites are not exactly contemporaneous. The latter possibility may have better standing because the normal conditions appear to lack constancy.

Secrron 6. Section 3, T. 30 N., R. 6 E., near Elk Point Ferry Landing, on Missouri river northwest of Ponca, Nebraska. and teeth. Makes a massive, prominent outcrop.

7 Marl, chalky and argillaceous in thin zone and containing fossils as indicated above. 
6 Chalk or marl, blue-gray in color but more resistant than overlying zone.

5 Limestone or marl, argillaceous, thin-bedded, with a slaty fracture. Many Inoceramus, Foraminifera and fish scales.

Total thickness of zones $5,6,7,8 \ldots \ldots \ldots \ldots \ldots \ldots \ldots \ldots \ldots \ldots \ldots$

4 Mostly covered but appears to be dark gray to black carbonaceous shale

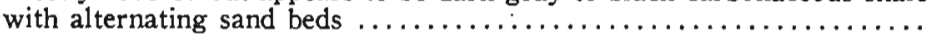

3 Shale, black, very carbonaceous, fissile in part but in uper half breaks with conchoidal fracture. Contains much primary selenite and has very bitter taste. In lower 5 feet occurs a medium- to coarse-grained, evenly bedded sandstone lens ranging up to three feet in thickness ............

2 Sandstone, gray to buff, medium- to fine-grained, micaceous, sugary texture; contains a small pelecypod fauna like that in zones $7 \mathrm{~b}$ and 9 of

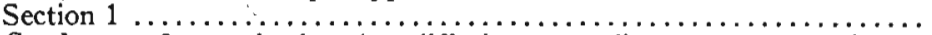

1 Sandstone, fine-grained, color differing according to amount of iron oxide cement. Alternate layers consolidated or friable. Contains pyrite and iron oxide concretions, much fragmented plant material, carbonized wood and abundant glauconite. This mineral comprises approximately 15 per cent of rock. Exposed to river level. Elevation

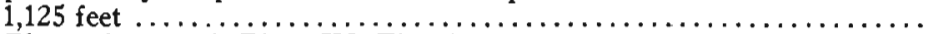
Photomicrograph Plate IV, Fig. A.

Zone 1 is probably the only member of the Dakota stage in this section and contains the marine invertebrates of zone 6a, Section 1. Zone 3 with its sandstone lens is more typical of the Graneros and compares with zone 14 of Section 3. As in the Aowa creek locality, Section 7 , the interval between the red concretionary glauconite zone and the Graneros is smaller than in Section 1 at Sioux City. The same conditions of relative age as will be described for the Aowa creek section probably exist at this locality.

SeCtion 7. Section 31, T. 30 N., R. 7 E., southeast of Ponca, Dixon county, Nebraska, near mouth of Aowa creek and along Missouri river bluff. Inoceramus and Foraminifera. Ripple marks with wave length 6 to 8

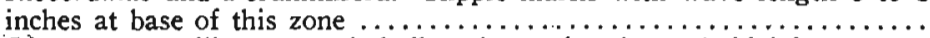

9 Limestone, argillaceous and chalky, slate-colored, conchoidal fracture .. Shale and sandstone, alternating with considerable calcareous and argillaceous material in upper part. Many thin zones of sandstone and shale $1 / 8$ to $1 / 4$ inch thick. Other layers range from 2 to 10 inches in thickness in 100 feet of outcrop. Much ripple marking and cross-bedding on small scale with cut and fill and an occasional mud crack. A large amount of fragmented plant material. The shale is blue-gray and fissile, while the sand is gray, fine- to medium-grained and contains abundant glauconite, fish teeth and scales, and small pelecypod casts .......... Thin section (07042) shows abundant glauconite, green hornblende, some brown hornblende, muscovite, weathered feldspars with the formation of a siliceous mosaic (probably a chalcedony), zircon, tourmaline, quartzite grains and calcite cement. Along seams through the section iron oxide replaces calcite in some cases with the development of rhombic pseudomorphs. The quartz grains are usually angular to subangular. Photomicrograph Plate IV, Fig. B and C.

7 Shale and sandsione. Shale is gray-blue, carbonaceous, contains Inoceramus, fish remains and plant fragments. Sand in thin regularly bed- 


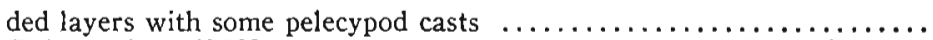

Quartzite grains common, weathered calcic feldspars and secondary iron oxide and silica. Glauconite is abundant, occurring principally as round grains, aggregates of extremely fine crystalline units and rarely as an alteration of feldspars. The abundance of weathered feldspars with development of calcite, chalcedony and occasionally glauconite indicates an arkosic character for the original sandstone. The alteration by weathering and ground water has occurred at the site of deposition. Grains angular to subangular with approximately 15 per cent curvilinear.

6 Shale, black, weathers fissile, contains selenite; nodules of pyrite and iron concretions ....................................

5 Sandstone, with tough reddish brown clay. One foot of hard red concretionary sand which contains much carbonized plant material in vertical position, and an irregular 1 to $1 \frac{1}{2}$-inch seam of lignite ...........

4 Sandstone, yellow, buff to brown-red, medium- to fine-grained, evenly bedded, but with occasional thin clay layer. Contains glauconite and small pyrite concretions. Near center is a thin, hard, red concretionary zone which makes a prominent ledge $\ldots \ldots \ldots \ldots \ldots \ldots \ldots \ldots \ldots \ldots$. Photomicrograph, Plate IY, Fig. D.

3 Shale, blue-gray, fissile and carbonaceous. One or two thin sandstone

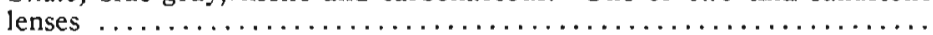

2 Sandstone and thin shale, irregularly bedded, grading downward to clay. Upper 4 feet contains concretionary zones of iron oxide. Elevation 1,120 feet. Exposed ................................... 1 Below water,level.

The major part of this section is younger than the Dakota stage, the base of the Graneros being located at the base of zone 6 . In several respects the relations of the Dakota and Graneros are very similar to those observed in Section 3 in southern Plymouth county. Zones 5 and 4 together are probably the equivalent of zone $6 \mathrm{a}$ of Section 1. If this is true, the overlying Graneros of Section 7, Aowa creek, is relatively older than the Graneros of Sections 1, 2, 3 and 5.

For a distance of one to two miles northwest-of Homer along the road to Hubbard and Jackson are several small exposures of Dakota sandstone. In these disconnected outcrops there appears to be a continuous zone of sandstone which makes a more or less massive outcrop in the bluff. At a point one and one-half miles northwest of Homer the following section was measured:

Section 8. Section 2, T. 27 N., R. 8 E., northwest of Homer, Dakota connty, $N \mathcal{e}$ braska, near bluff road.

Sandstone, buff to brown, medium-grained, friable, with few small iron concretionary nodules. Cross-bedding common in zones ranging from two or three inches up to one and one-half feet. Foresets inclined principally to N., NE. and NW., though some are seen to be inclined to $\mathrm{SE}$. Truncations horizontal and inclined in northerly directions. Elevation at base of section approximately 1,120 feet. Exposed 16 to 18 feet.

Photomicrograph, Plate IV, Fig. F. 
Above the section described the slope is covered for approximately 180 feet to the top of the hill, but an occasional small protruding ledge indicates the presence of thin hard concretionary sandstone layers up to 60 feet above the exposure. These beds are overlain by a chalky limestone containing Inoceramus shells. A fresh water spring issues from the lower part of the sandstone described above, so it is probable that the medium-grained sandstone is underlain by a siltstone, a clay, or alternating shales and sandstones.

Section 8 is one of the exposures of sandstone nearest to Dakota City and occupies a position in the bluffs such as described by Meek and Hayden. ${ }^{140}$ Unless the exposures were much better at the time Meek and Hayden visited the area it is doubtful if they obtained conclusive evidence from this section.

Continuing southeastward along the northeast facing bluffs which border the alluvial plain of Missouri river are several small exposures similar to Section 8 .

In the bluff two and one-half miles southeast of Homer, Section 20, T. 27 N., R. 9 E., Dakota county, another small exposure was observed.

Section 9

Sandstone, buff to yellow-gray, fine- to medium-grained. Appears as a massive bed but on weathering shows many thin cross-bedded zones. Foresets inclined to east and southeast in zones up to two feet thick. Truncation planes horizontal and inclined to southwest and northeast and marked by many small concretions. Cementing material chiefly calcite but with some iron oxide. This outcrop and adjacent ones have been described by previous workers as having the characteristics of a quartzite. Thickness exposed 25 feet.

Photomicrograph, Plate IV, Fig. E. Iron oxide cemented portion.

The most complete and typical exposure of the Dakota rocks in northeastern Nebraska in the type area is found about one and threefourths miles south of Homer, Dakota county. This section is over five miles from Missouri river and almost two miles from the bluff line at Homer, so it is doubtful if Meek and Hayden or other early workers observed it. No mention of this locality is made by Gould, ${ }^{141}$ Condra ${ }^{142}$ or Burchard ${ }^{143}$ in their detailed discussions of the stratigraphy of Dakota county and adjacent areas.

The upper part of the section is exposed in a road cut on U. S. Highway No. 77 about three-fourths of a mile southwest of the principal part of the section. 'The most complete part of the section

140 Meek, U, S. G. S. Terr., Vol. 9, p. XXV, 1876.

141 Gould, Kans. Acad. Sci. Trans., Vol. 17, p. 137, 1900

142 Condra, U. S. Geol. Surv. W. S. Paper 215, pp. 8-11, 1908.

143 Burchard, Acad. Sci. and Lett. Sioux City, Proc., Vol. 1, pp. 147-149, 1903-4. 
is found immediately above a steep cut bank at a sharp bend in Omaha creek. The extremely abrupt changes of the rocks of the Dakota stage make it highly desirable to find a single section with as much of the sequence as possible. Correlations of zones and members where only a few feet are exposed is extremely difficult and the results are questionable.

Section 10. SW. 1/4 Sec. 23, T. 27 N., R. 8 E., and NE. 1/4 Sec. 26, T. 27 N., R. 8 E., about 2 miles south of Homer, Dakota counly, Nebraska. Elevation Omaha creek at base of section approximately 1,115-1,120 feet.

9 Sandstone, red, brown, fine-grained, micaceous, iron oxide and clay cement, in thin beds, with concretionary development. Principal grades between one-fourth and one-sixteenth $\mathrm{mm}$. Larger grains curvilinear to subround. Minute cross-bedding seen in well compacted zones. Presence of glauconite uncertain.

Best observed in section 26 east side of Omaha creek. Exposed ....... Lower half more or less massive bed, upper half in several thin beds with differing cementation. Lower part with foresets of cross-bedding

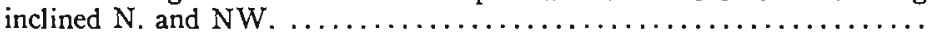

7 Shale and sandstone, alternating in thin beds. Sands are buff, finegrained, ranging to siltstone, micaceous; shales are gray, plastic and micaceous, in some places grading to silt. Entire zone contains much

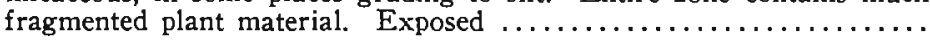

6 Sandstone, buff to yellow, friable, well sorted, medium-grained, uniformly cemented by iron oxide, micaceous. Grades upward to less friable and firmly cemented ferruginous and calcitic rock sometimes called "quartzite." Top 4 to 5 feet contains much gray clay in thin seams, nodules and as pebbles. Middle and upper middle parts show small oscillation ripples with crests trending NW.-SE. Lower part crossbedded with foresets inclined $W$. and SW. The zone 10 to 14 feet from base contains much fragmented leaf material and an occasional

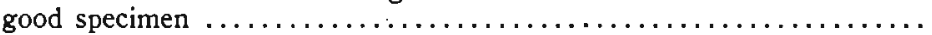
Minerals: Glauconite (?), zircon, tourmaline, green hornblende, leucoxene, basic feldspars, quartzite and chert.

Many grains show excellent rounding on several surfaces, with deep pitting and frosting. This type, however, is not conclusiye of wind abrasion.

5 Sandstone and shale, alternating, with single beds ranging from a fraction of an inch to over three feet in thickness. Impractical to subdivide this zone as individual layers change in composition within a few feet laterally. Sandstone is white to gray, fine-grained and of wide range in cementation. Many of the sand beds are capped by a hard iron oxide concentration, especially where ripple marks are preserved. Crossbedding in middle part on large scale, foresets inclined to S., SW. and $\mathrm{SE}$. Clay is gray-drab, carbonaceous and occasionally quite sandy, and with many thin limonitic concretionary zones. There is a definite interfingering of sand and clay. A channel cut in the thin alternating layers of sand and clay near the base is filled with sand containing lenses of clay, but unconformable with the sides of the channel cut by currents. This channel probably was cut by the current of the stream depositing the sands and clays. The contact with zone 4 is unconform-

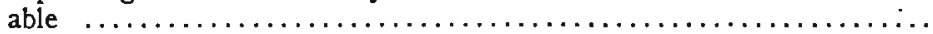

4 Sandstone, white to gray, fine-grained, micaceous, small cross-bedding to S., SW. and SE. TOp of member has a concretionary zone at the

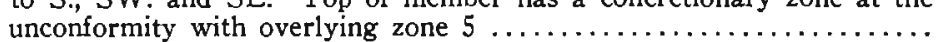


3 Sandstone, gray to white, medium- to fine-grained, friable, micaceous, grains subangular to subround and many curvilinear; many well frosted. Massive beds. Some small cross bedding. Contact with zone 2 irregu-

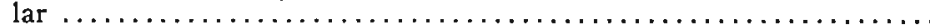

Photomicrograph Plate IV, Fig. $\mathrm{H}$

2 Sandstone, gray to yellow and buff, medium- to fine-grained, friable, micaceous. In single massive bed. Very little different from zone 3 except for greater amount of iron oxide as cement ................

1 Sandstone, like zone 2, but separated by a wavy irregular line of iron concretions and a few small clay balls. Cross-bedding prominent, foresets inclined to $\mathrm{S}$. and SW. Exposed to creek level .................. Photomicrographs Plate IV, Fig. I and J.

Zones 1, 2, 3 and 4 are almost identical in several respects. The large amount of wear and frosting on the grains, the absence or small amount of iron oxide as cement and the similarity in size grade distribution and the scarcity of accessory minerals indicate that these zones might be considered as a single member. The general regularity of bedding, and, where cross-bedding occurs, the common direction of foresets indicates a condition of deposition with little variation. Such a condition could be accomplished in water of only moderate depth, or in an estuary some distance from the mouth of the stream. The currents which supplied the medium- and fine-grained sand at the same time sorted the material and deposited it with minor foreset zones. The writer believes the sand came from a nearby beach where wave action had been efficient in sorting and abrading the grains. The direction of inclination of the foresets indicates a general south of southwest course of the currents with the source toward the north and northeast.

Zone 5 apparently was deposited in a broad, shallow estuary, or is part of a delta built by a stream rapidly aggrading and with a meandering course. Cut and fill is common in this zone and the rapid change in thickness and composition of many of the units indicates a shifting current. The stream advanced its delta southward, overlapping the estuarine or littoral deposits of the lower zones.

The sands of zone 6 probably were deposited in a slowly encroaching sea which covered the deltaic deposits of zone 5 . The presence of oscillation ripple marks and the uniform cross-bedding indicate the shallow ocean environment. Conditions changed back and forth; it is doubtful if one could draw the exact boundaries separating the deposits made directly by a stream emptying into a bay or gulf from the sands reworked and deposited by waves or littoral currents. In either case well sorted sands could be deposited evenly or in uniform lenses, or muds could be included as thin irregular lenses or as inter- 
laminations with the sands. It is an environment where one set of conditions characteristic of a gulf or bay may control for a period of time and then be displaced by a new set which is dominated by the stream factors.

Zones 7,8 and 9 add very little to the general conclusions above. In zone 8 the direction of inclination of foresets is different from that noted in the lower members, but this may be the result of shifts in the position of one of the mouths of the stream building the delta, or a change in detail of the course of a littoral current.

Of some significance is the absence of undoubted glauconite in the sandstones of this section. The writer has no explanation to offer. In all other sections in the type area one or more members of the Dakota stage contain some glauconite.

South of Dakota county, Nebraska, along the Missouri River bluffs in Thurston and Burt counties, more or less continuous evidence of the Dakota stage may be observed. The exposures near Tekamah, about thirty miles south of Sioux City, mark the southern limit of the rocks which appear to belong in the same class as the type area Dakota. The sandstones are variable in, color, depending on the amount of iron oxide present and the degree of oxidation or hydration. Concretions are common. The rocks are fine-grained, with bedding which is uneven and cross-laminated, with foresets inclined most commonly to the south, southwest and southeast.

An exposure observed eleven niles north of Tekamah in a farm lot on the west side of Nebraska state highway No. 51 shows several feet of irregularly bedded coarse-grained conglomeratic and ferruginous sandstone. The foresets of the cross laminations are inclined to the southerly quadrants. At the top are gnarly concretions and mixtures of thin clay lenses. At the base of the conglomerate is a more regularly bedded fine-grained gray and yellow sandstone with southeast and southwest inclined foresets. The six feet of this sandstone exposed is very similar to the lower four zones of Section 10, just south of Homer.

About eight miles west of Decatur, Burt county, on Elm creek, near the Lyons-Decatur highway bridge, is an isolated exposure of considerable significance.

Elm creek has cut through the sandstones and shales of the Dakota stage for a distance of about one-half mile. There is a heavy mantle 
of drift and loess which extends below the creek level on both sides of the Dakota exposure. The Dakota apparently was a topographic high in preglacial time.

In detail the section is as follows:

ZoNe

Section 11

B. The younger sediments which fill the channel.

Shale, clayey. Near unconformity is blue-black but grades outward to a gray, buff and mottled color; at the unconformity the bedding is poor but toward the south it is thinly laminated, with sandstone zones interbedded, showing concretionary development and ripple marks. The upper clays and silts contain some good leaf impressions and much frag-

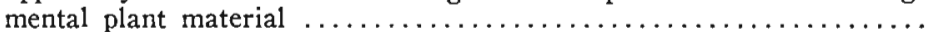

A. The older part of the exposure.

Sandstone, buff, yellow, medium- to fine-grained. Usually the sorting is very good in individual beds; micaceous, and friable. In the lower 6 to 8 feet the sands are intricately cross-bedded with foresets inclined in every quadrant, but with NE. and NW. directions predominating. The truncation surfaces are in many cases ripple marked, most of these marks being of the symmetrical type. Dicotyledonous leaves are found in the upper middle fine-grained beds. Toward the top the beds are silty and shaly and more thinly bedded. Sample from a lower zone contains

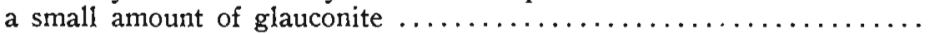

FEET

"The section of the Dakota shows two types of rock; one a series of fine-grained micaceous sands, with highly cross-bedded and rippled zones, and the other, clayey shales and silts with thin layers of sand. These rocks are separated by an unconformity which cuts across the exposure from top to bottom. The writer interprets this condition to be one of a channel cut in a littoral bar and then filled with clay and silts as the stream current was able to deposit materials in its bed. Only one side of the old channel is well exposed in the valley wall of Elm creek, but upstream several hundred feet the fine-grained cross-bedded sandstone is exposed again, indicating the other bank of the channel. The present exposure in the creek is at an angle with the old channel so that a direct measurement between banks is not the true cross section width of the channel. The channel was probably about 300 feet wide at this point.

There is no question in the writer's mind concerning the unconformable relationships of this section. The sandstone beds of $A$ in the above description are distinctly bevelled and do not grade or interfinger into $B$. The curvature of the plane of separation and the concentration of iron oxide along this plane and the character of beds of zone $\mathrm{B}$, all preclude the possibility of a fault. The commonness of such a condition of cut and fill in the Dakota rocks also argues for this conclusion. 
Many other small outcrops, showing only a few feet of sandstone, or interbedded sandstones and shales, were visited in Dakota, Dixon, Thurston and Burt counties, Nebraska. None of these exposures adds to the detailed knowledge of the Dakota stage, as very little new information may be derived from them. It is true these sections help one to follow the formations in the field and to understand better the general distribution of the different zones, but it is also true that a single zone often changes character abruptly, and two sections at the same level only a few hundred feet apart, but concealed in the interval, will show distinctly different types of rock. 


\section{CHAPTER VI}

\section{THE DAKOTA ROCKS OF ADJACENT AREAS}

No attempt is made to give a complete discussion of all the exposures of rocks called Dakota in western Iowa, southern Nebraska, northern and central Kansas, or elsewhere. The writer has studied in the field practically all of the exposures in the areas named and can make comparisons and correlations with the rocks in the type area.

In southwestern Iowa, particularly in Cass, Montgomery, Page and Guthrie counties, there are numerous exposures of rocks which the writer believes are equivalent to parts of the Dakota stage of the type area. These rocks have been correlated generally with the Dakota because of their lithologic characteristics and the local abundance of dicotyledonous leaves, which are very similar to those reported by Bartsch $^{144}$ for western Iowa. The writer has not made a detailed study of these leaves.

Continued field work on the Dakota rocks in southwestern Iowa has failed to locate a horizon containing a marine or brackish water invertebrate fauna. In fact, the only locality that is known to the writer to have yielded invertebrates is at Sioux City and nearby sections, as previously described.

The usual exposures of rocks correlated with the Dakota are small, and the beds carl be traced laterally only a few thousand feet or fractions of a mile. The overburden of glacial drift is normally rather thick, and the possible lenslike nature of the Dakota sandstone makes it difficult to find continuous outcrops.

A section of the Dakota one mile southwest of Lewis, Cass county, Iowa, may be taken as characteristic for the west-central Iowa region.

6 Sandstone, white to buff and yellow, fine- to coarse-grained, friable. Appears to grade upward to finer sands; a layer of gray thinly laminated clay appears 18 to 20 feet from base but is not continuous. There are many very local and irregularly exposed clay conglomerate zones with boulders of clay up to 10 and 11 inches in diameter and 3 to 4 inches thick.

These zones, though occurring at irregular horizons, are discontinuous and are nearly horizontal on wavy surfaces. The pebbles and boulders of clay have their longer axes parallel, or nearly so, to the surfaces on which they rest. The differences in amount of iron oxide cement give

144 Bartsch, Bull. Lab. of Nat. Hist. S. U. I., Vol. 3, No. 4, pp. 178-180, 1896. 
ZONE

FEET

the sandstone a locally banded appearance. About 21 feet from the base of this zone a gray shale bed increases in thickness toward the east and southeast. Eastward the base of the shale zone contains a

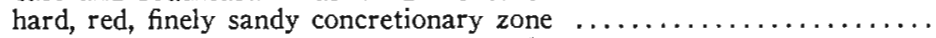

5 Shale, green to gray, thinly laminated and resting on a wavy, hummocky surface, which is brown to red, owing to concentration of iron oxide. Much of the shale occurs as conglomerate pebbles. The zone is irregular and probably not continuous for a great distance. Aver-

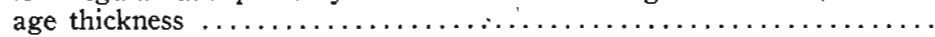

4 Sandstone, yellow to buff and white, friable, coarse-grained. Contains many irregular zones of poorly developed iron oxide concretions and clay conglomerate pebbles. Cross-bedding inclined to south-southeast ..

3 Sandstone, generally covered except for very small exposures, where it

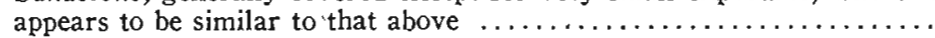

2 Sand'stone, and conglomerate shale, with much iron oxide and interfin-

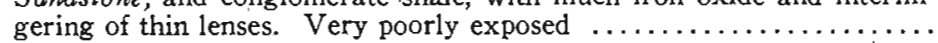

1 Limestone, upper Pennsylvanian. Exposed, approximately .............

About one-fourth mile northeast of the exposure described in the previous paragraphs there is a good outcrop of the hard red ferruginous medium- to coarse-grained sandstone that is so characteristic of the Dakota of central and northern Kansas. The few ledges show excellent cross-bedding with foresets inclined to the south-southwest and west at an angle of about 15 degrees. The elevation of this exposure is about the same as the top of zone 6 in the previous section,

In southern Montgomery county, Iowa, along the bluffs of the east branch of Nishnabotna river, and particularly south of Red Oak and adjacent to Coburg, are several exposures typical of Dakota sandstone

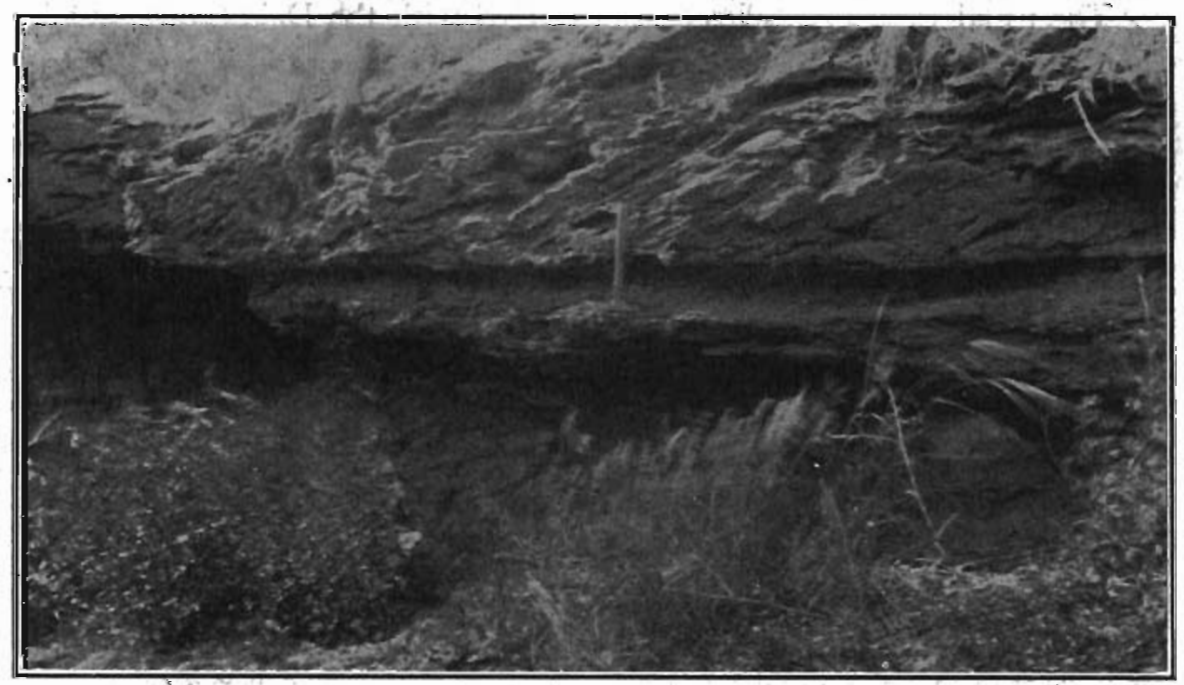

Fig. 27.-A series of regular foresets seen in zone 5 of Section, 13, at Coburg, Montgomery county, Iowa. 
and conglomerate. A section measured just east of Coburg, in the south half of section 30, T. 71 N., R. 38 W., has the following characteristics.

\section{SECTION 13}

ZONE

6 Silt to clay, gray to buff, contains much fragmented plant material and carbonized wood. Exposed

5 Sandstone and conglomerate, dark brown, red and yellow. Very irregularly bedded with particles ranging from sand to cobble grades; cement very unevenly distributed with some concentrations as concretions surrounding yellow friable masses. The pebble zones are irregularly distributed, though in detail they appear to be concentrated as foreset beds or small depression fills. The pebbles and cobbles are principally a

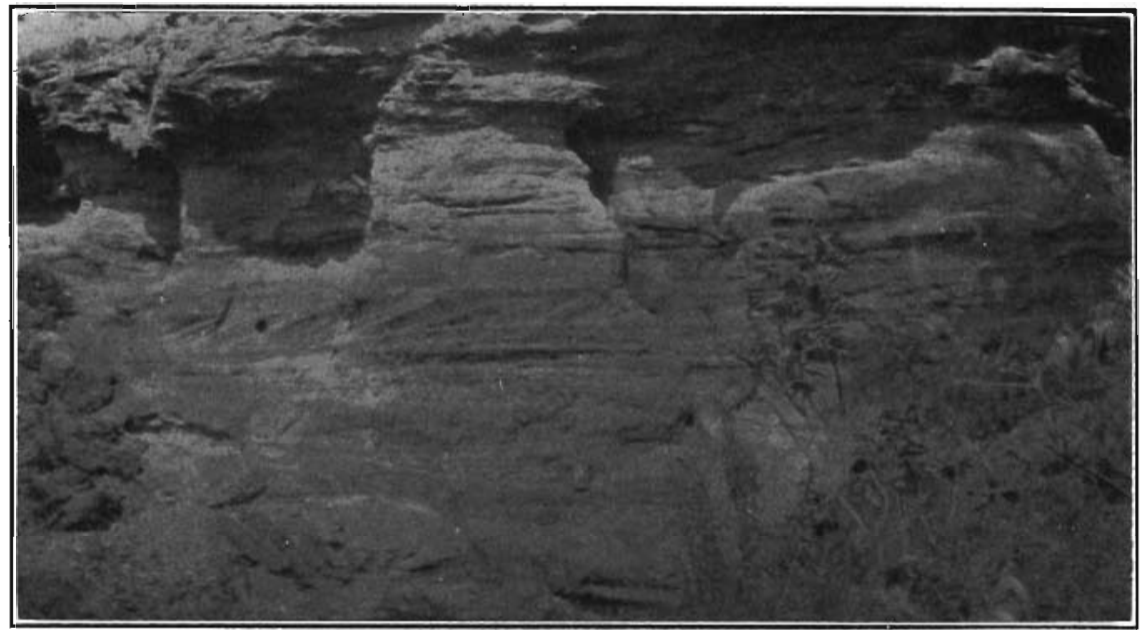

Fig. 28.-The upper ferruginous sandstone and the friable yellow irregularly bedded and conglomeratic sand at Coburg, Montgomery county, Iowa.

brown chert and gray vein quartz. The cross-bedding is normally constant for single zones, but the variety includes inclinations of foresets to the southwest, west and south. Figure 27 shows one of the upper hard ferruginous cross-bedded zones of the coarse sand and peanut gravel.

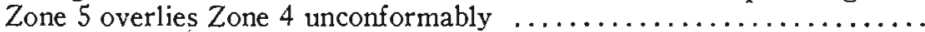

4 Sandstone, yellow, buff and gray ; wide variety of sizes of grains, ranging from cobbles to medium-grained sands. Cementation differs, controlling color and friability of rock; not generally as well cemented as Zone 5. Color bands follow cross-lamination directions. Throughout exposure practically every possible direction of cross-bedding may be noted; in the upper part the directions of foresets are dominantly in the north-northwest quadrant; in the central and lower parts the foresets range from southwest, south, southeast, to east. In several zones there are definite 2-to 3 - inch bands of pebbles which are usually nearly horizontal or inclined at very low angles; the less sand contained in the pebble zone the more horizontal is the position. Figures 29 and 30 show two views of the pebble bands and cross-bedded zones of this part

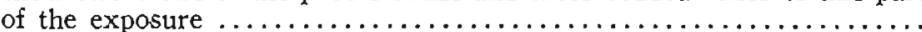

3 Conglomerate, pebbles up to three-fourths inch in diameter. Makes a

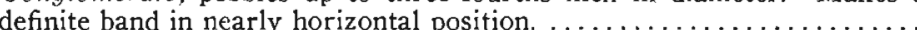




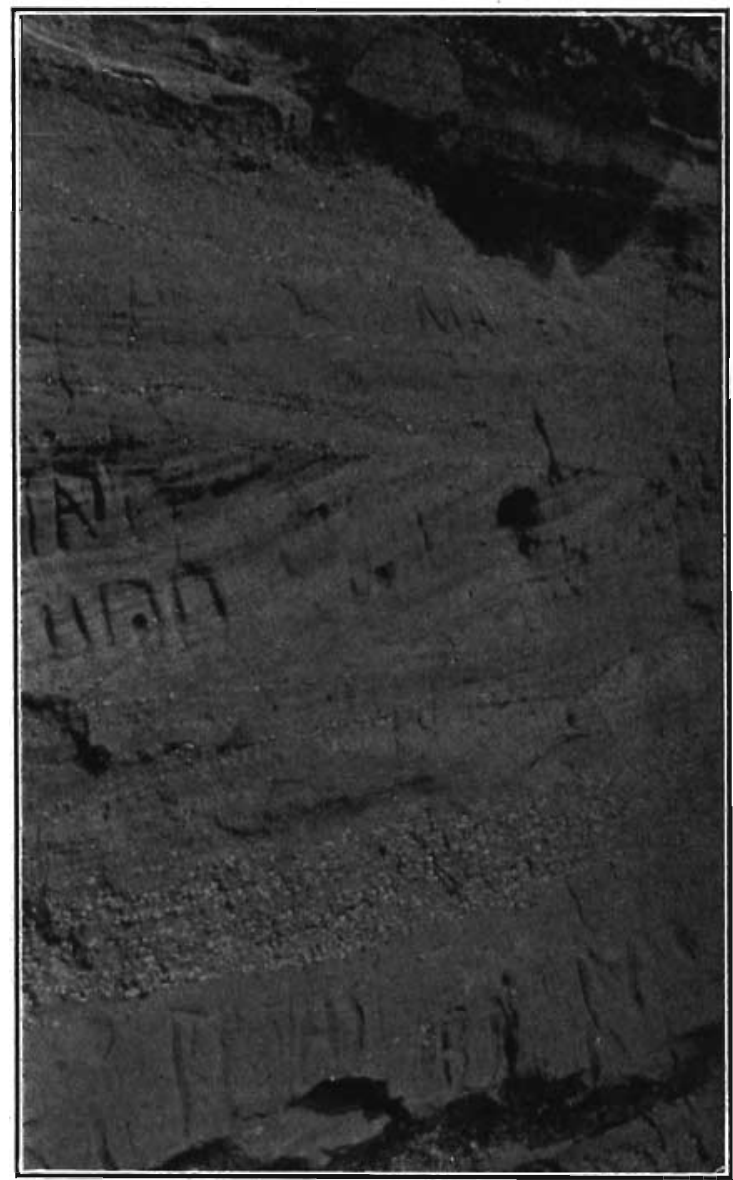

Fig. 29.-Detailed view of yellow, friable sandstone with conglomerate zones. Note the relation of the foresets and pebble band on the horizontal truncation planes.

2 Sandstone, medium- to coarse-grained at base grading to finer sands at top. Foresets inclined to south-southwest. At base is a single layer of pebbles lying on irregular contact of Zone 1

FEET

1 Sandstone, yellow to buff, medium- to coarse-grained with conglomerate in some of the foreset zones. Cross-bedding inclined to the north-north-

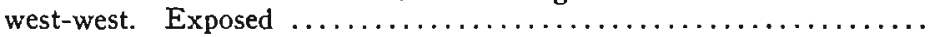

In the northwest part of section 17, T. 71 N., R. 38 W., Montgomery county, north of Coburg, Iowa, there is another good exposure which shows a conglomerate and peanut gravel similar to that just described in the locality east of Coburg. Lonsdale ${ }^{145}$ has described this material as puddingstone. The upper part of the rock is not well exposed, and there are only 20 feet contained in the fresh exposure.

145 Lonsdale, E. H., Iowa Geol. Survey, Vol. IV, pp. 381-451, 1895. 


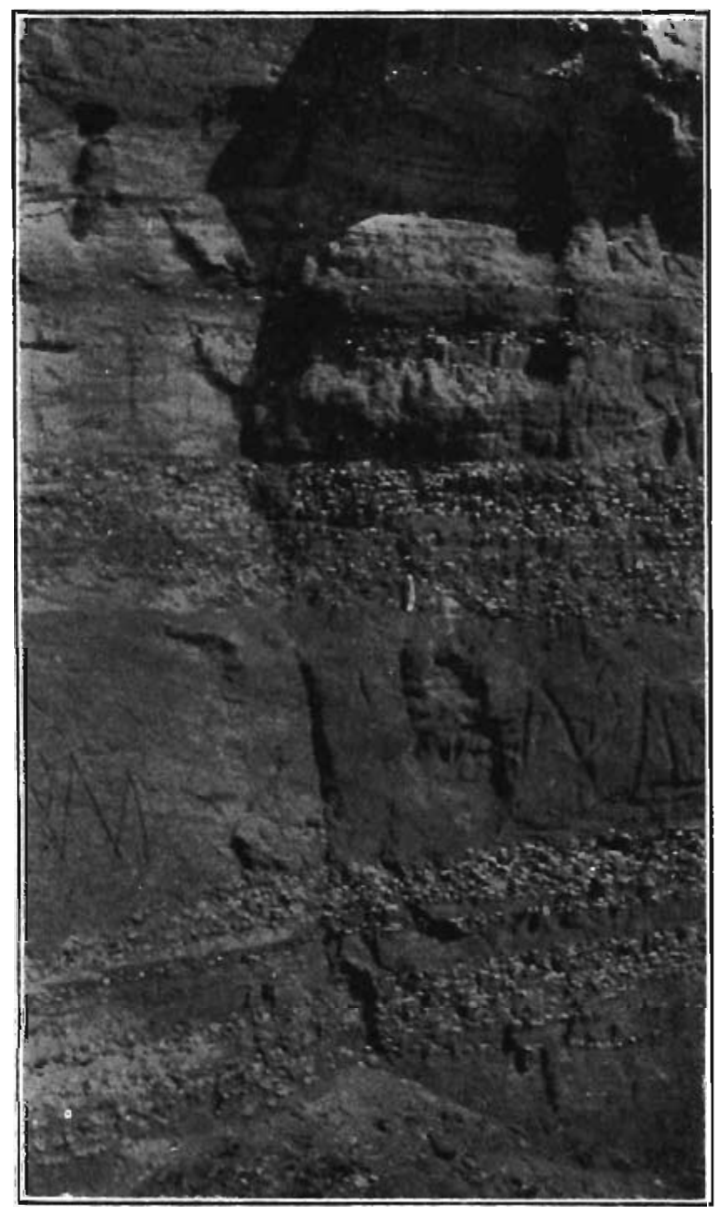

Frc. 30.-A detail of part of the section below Figure 29 . Note the reverse directions of foresets in the zone below the knife.

This shows a pebble to cobble conglomerate with a matrix of coarse sand, clay balls, and considerable iron oxide cement. The rock is much more tightly cemented and is of a darker brown and red color than that seen at Coburg. A very fresh exposure shows a lighter brown color. In general the cobbles are coarser from the base upward; below the puddingstone conglomerate there is a gradation to a medium fine-grained yellow, buff micaceous sandstone.

The cross-bedding of the puddingstone differs but is predominantly to the south-southwest with an inclination of 18 degrees. In the lower fine-grained sand the cross-bedding is also mainly to the south-southwest but with some thin zones consistently to the southeast. 
The writer knows of no other locality in southern Iowa where as thick a section of coarse material of Dakota age occurs. However, west and north of this locality, approximately 45 to 50 miles and just east of Louisville, Nebraska, there is a similar exposure. As these two exposures have a great deal in common, including the composition of the pebbles, the texture and the bedding, it is quite possible that at one time they were a part of a series of lenses which extended from east to west and bordered the old shore line.

In southern Nebraska, near Fairbury, Beatrice, Hastings and Endicott, are found exposures of fine-grained and buff to yellowish sandstones which in some cases contain dicotyledonous leaves.

An exposure along the Chicago, Burlington and Quincy railroad on the south bank of Platte river, about two and one-half miles southeast of Ashland, Nebraska, shows the Dakota sandstone resting directly on the Upper Pennsylvanian limestone. The lower part of the sandstone is a coarse-grained brown poorly cemented type, with foresets inclined 20 to 22 degrees to the west and northwest. The series continues with little change except for local alterations in exact direction of cross-bedding and minor differences in texture. About 20 to 25 feet above the base the grain becomes very coarse and pebbly with foresets often showing in the coarse-grained zones. About 30 feet above the limestone the cross-bedding is more intricate, there is a greater range in thickness of zones, and changes in the grade of the sand are more abrupt. This zone is 12 to 14 feet thick. The upper six to seven feet of sandstone is coarse-grained and almost a conglomerate. Above this the section is poorly exposed and covered by drift and loess from above. The total exposure is about 50 feet thick.

An excellent section is exposed on the main line of the Chicago, Burlington and Quincy Railroad near mile post 112, east of Endicott, Nebraska. The exposure in the cut shows about 15 feet of soft gray and yellowish fine-grained sandstone which in places grades locally into clay or a very argillaceous sand: The upper half of the exposure is marked by thin limonite-colored hard sandy lenses which are very irregular in their extent and range from horizontal to steeply inclined positions. The limonite-colored zones mark a cementation process which took place probably soon after the deposition of the sandstone. Along some of the thicker zones of cementation hard and gnarly concretions are developed. 
A large lens of nearly pure sand, with very little clay but with considerable iron oxide cement, occurs at one place. The lens departs directly from the argillaceous sandstone which comprises most of the rocks in the cut. This condition is evident on both sides of the track. On the east side of the cut the sand interfingers with the argillaceous material. The inclination of the foreset beds of this sandstone is dominantly to the south, with some inclined to the southeast and southwest. A few zones of the foresets are 8 to 10 feet long and are inclined at an angle close to 22 degrees.

The irregularity of some of the cross-bedded zones, the variety of truncations, the interfingering of clay and sandstone lenses, the local cuts and fills, all indicate the variety and rapid changes in the conditions of deposition of the materials in the Endicott section.

At several localities northwest of Fairbury, Nebraska, the Dakota rocks may be observed. Along the St. Joseph \& Grand Island railroad at mile post $1571 / 2$, approximately five miles northwest of Fairbury, the exposures show 20 to 25 feet of gray and brown clay with thin sandstone zones, overlain by three to five feet of massive bedded medium- to coarse-grained light colored sandstone. This in turn is overlain by 20 to 35 feet of gray clays which are mottled gray and red with many thin sandstone lenses. Unconformably overlying the last mentioned clay is a hard fine-grained calcareous sandstone. This sandstone appears to be more or less concretionary and occasionally weathers in dark red to brown blocks. It is very similar to the calcitic, concretionary sandstone of zone $6 \mathrm{a}$, Section 1 , Sioux City, Iowa.

In section 19, T. 3 N., R. 2 E., northwest of Fairbury, Nebraska, is a section of Dakota clays and shaly sands immediately overlain by the Graneros member of the Colorado stage. The section observed at several points in the southwest corner of section 18 and the adjacent part of section 19 is given below.

ZONE

SeCtion 14

8 Limestone and shale, apparently grading from below. Abundant Inoceramins.

7 Shale and clay, gray and brown, containing many sandstone lenses onefourth to one-eighth inch thick. Upward the zone is brown and shows

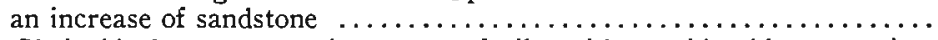

6 Shale, black to gray, carbonaceous, fissile, with considerable concretionary material. Grades upward to brown thin sandy shale .............

5 Calcite cone-in-cone, irregular in distribution. One 2-inch layer with 3 inches of impure limestone at top. The 3 feet of exposure is capped

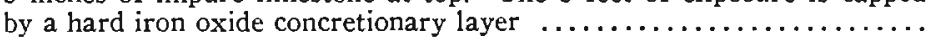


4 Clay and shale, some dark gray to black, carbonaceous, and some parts - fissile. An occasional thin sand lens .............................

3 Lignite, impure, soft and earthy, grades into a highly carbonaceous

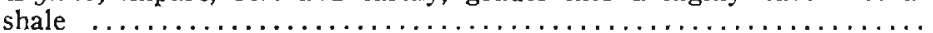

2 Clay, gray, unctuous, poorly exposed $\ldots \ldots \ldots \ldots \ldots \ldots \ldots \ldots \ldots \ldots \ldots \ldots \ldots \ldots \ldots \ldots$

1 Sandstone, yellow, concretionary and friable, with alternating gray clays and siltstones. Irregularly exposed in creek bank. Approximately

In the sections described above there are two features which appear to be of some importance when one is attempting to correlate the conditions of deposition with those of the formations in northeastern Nebraska, adjacent to the type locality. The occurrence of the gray interfingering silts and clays below the fine yellowish sands which underly the lignite is very typical of the Sioux City section. The occurrence of cone-in-cone is suggestive of the Comanchean formations of central Kansas. It will be noted in the sections described above that sandstone is relatively rare, and in particular as thick massive beds. The gradation at the top into the Graneros formation (zone 7) which in turn grades to the Greenhorn formation (zone 8 ) of the Colorado stage makes it difficult to draw any distinct line of separation between these various formations.

Section 14 and the exposures along the St. Joseph \& Grand Island railroad northwest of Fairbury are in the locality described by Hicks ${ }^{\mathbf{1 4 6}}$ as yielding a fauna of marine invertebrates and later described by White ${ }^{\mathbf{1 4 7}}$ as carrying a fresh water fauna. The writer was unable to find any fossils in this locality.

In sections 11 and 12, T. 2 S., R. 3 E., Washington county, Kansas, just south of the Spring creek bridge about five miles north of the town of Washington, may be seen a section of yellow, brown friable and medium-grained sandstone. The cross-bedding in this sand has a wide range, foresets being observed with inclinations to the north, northwest, west and southwest. Near the top of the cut bank, the highly cross-bedded zone is overlain unconformably by an irregular zone of interfingering sandstones and argillaceous shales. At the base of this upper zone the grain is very coarse, with an occasional pebble of quartz or flint and many small clay balls and concretionary siltstones. The cross-lamination of the upper sandstone is predominantly inclined to the west-southwest, the foresets having an angle about 12 to 15 degrees and being 20 to 25 feet long. To the east of this exposure

116 Hicks, L. E., Amer. Assoc. Adv. Sci. Proceedings, Vol. 34, pp. 217-219, 1885.

147 White, C. A., C. S. Natl. Museum Proc., Vol. 17, pp. 131-138, 1894. 
and up the hill there is very little rock exposed, but talus blocks of dark red coarse-grained concretionary cross-bedded sandstone may be seen.

Another section in Washington county, Kansas, in the northwest part of section 32, T. 2 S., R. 4 E., along Mill creek, shows the wide range in the nature and relationships of the Dakota section. A generalized description follows:

\begin{tabular}{|c|c|c|}
\hline \multirow[b]{2}{*}{ ZONE } & Section 15 & \multirow{3}{*}{ FEet } \\
\hline & & \\
\hline 6 & $\begin{array}{l}\text { Float, much like Zone } 5 \text {, and typical of the coarse-grained ferruginous } \\
\text { Dakota sandstone. }\end{array}$ & \\
\hline 5 & 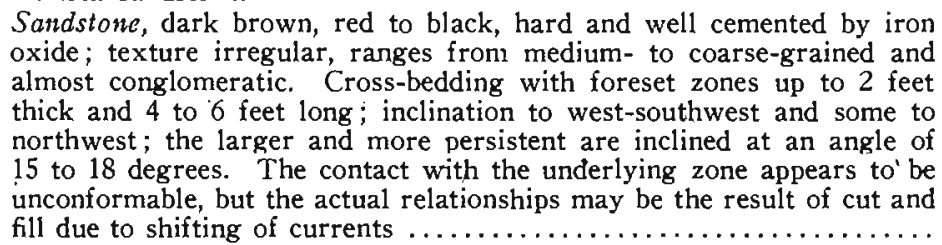 & $24-28$ \\
\hline 4 & $\begin{array}{l}\text { Sandstone, gray to brown, calcitic, with small amount of iron oxide, } \\
\text { similar to the rock sometimes described as a quartzite. Lower part in- } \\
\text { tricately cross-bedded on a very small scale, zones of foresetting } 10 \text { to } \\
14 \text { inches thick, foresets inclined } 10 \text { to } 12 \text { degrees in south, southwest } \\
\text { and west quadrants. Upward the sand is poorly cemented and changes } \\
\text { color to a yellowish brown. The lower } 5 \text { feet of the friable zone is } \\
\text { evenly bedded, while the upper } 10 \text { to } 15 \text { feet repeats the intricate cross- } \\
\text { bedding seen in the lower part but with long gently sloping foresets } \\
\text { with southwest, west, northwest inclinations. The well cemented } \\
\text { "quartzitic" type of rock may be a local phase, but it is a characteristic } \\
\text { feature of the rocks of this region. The similarities with the calcitic } \\
\text { sandstone of the type area near Sioux City are close................. }\end{array}$ & \\
\hline 3 & Shale, brown and gray, calcareous. Permian ......... & \\
\hline & & \\
\hline
\end{tabular}

In the southeast quarter of section 32 , near the rocks described above, gray and brown clay and shale series with the red hematitic sandstone lenses is very well developed. The shales continue to the crest of a prominent ridge, which is 75 to 80 feet higher than the base of the sandstone of Section 15. The position of these rocks cannot be accounted for by dip and it appears that the ridge was probably a topographic high at the time of the deposition of the coarse-grained highly cross-bedded ferruginous sandstone of zone 5 of the section just described. The contact with the Permian rocks is also one of distinct unconformity, as may be seen about one and a half miles north of the section just described. At this place a "butte", of Permian calcareous shales and thin limestones stands 30 to 35 feet above the base of the irregularly cross-bedded yellow friable sandstone of $\mathrm{Da}$ kota age. 
The irregular relationships of the characteristic medium- to coarsegrained ferruginous sandstone horizon are seen in many localities in Washington county. Along the Washington-Clay county line in sections 33, 34 and 35, T. 5 S., R. 2 E., and sections 3 and 4, T. 6 S., R. $2 \mathrm{E}$., is a very instructive section.

In the highway cut at the south side of section 35 only clay and soft yellow sandstone are exposed, overlying a red mottled gray clay. This section continues down to the creek level about 30 to 35 feet lower. At a large cut across the north center of section 3, T. 6 S., R. 2 E., the exposure at the same level is entirely of a soft, gray-yellow sandstone with very thin alternating beds of clayey shale and argillaceous sandstone. About 25 feet below the top of the cut is a hard gray-brown to red sandstone with some conglomeratic grains of quartz and bearing dicotyledonous leaf material. On the opposite side of a small draw about one-quarter mile west this leaf-bearing sandstone is much thicker and continues to a level 50 to 60 feet lower. It is apparent that the coarse-grained ferruginous sandstone increases in thickness from about 8 feet on the east side of the draw to approximately 70 feet within one-fourth of a mile to the west. This probably is an old channel fill, the coarse-grained sands being the alluvial and bar deposits. In section 3, as previously indicated, the leaf-bearing sand is overlain by soft gray and yellow sandstone. At the top of the hill there is much float of a hard ferruginous concretionary sandstone similar to that just described as the stream fill. It appears then that the ferruginous concretionary sandstone may be repeated at more than one elevation and is not a distinctive stratigraphic unit; the conditions responsible for such stream deposition alternated with conditions which deposited finer grains and silty sediment.

The writer has observed and measured sections in a large number of localities in Clay, Cloud, Ottawa, Mitchell, Lincoln, Russell, Ellsworth, Saline, McPherson and Rice counties of central and northcentral Kansas. These sections show without much question the irregular characteristics of the Dakota rocks. There are shales, siltstones and fine- to medium-grained sandstones in thin alternating beds, normally poorly consolidated and without continuity over a large area; and there are hard concretionary ferruginous sandstones which thicken and thin, have a wide range in grain, and have more or less persistent cross-lamination; these in some cases are unconformable with the 
alternating shales and sạnds first mentioned. It is believed that the coarse-grained cross-bedded ferruginous sandstone was deposited as a channel fill by streams which extended their courses over the deltaic and adjacent shallow water deposits represented in the lower section.

In northern and central Kansas the conditions described above occur rather commonly. Many of the ferruginous coarse-grained channelfill sandstones carry a dicotyledonous leaf flora, and the writer has collected invertebrates from beds immediately overlying this type of rock. The lower sands and shales also contain some dicotyledonous leaves, and certain zones locally are filled with fragmented plant remains and occasionally are lignitic. The relationship of the leaves in the lower zone to those in the stream channel deposits is not certain to the writer. However, he made a collection of leaves from the gray and iron-stained clays of section 3, T. 16 S., R. 9 W., southwest of Ellsworth, Ellsworth county, Kansas, and these were identified by Dr. E. W. Berry of Johns Hoplkins University in 1925. The determinations by Berry are listed below.

\author{
Andromeda parlatorii Heer \\ Andromeda praffiana Heer \\ Dammara borealis Heer \\ Eucalyptus Dakotensis Lesquereux \\ Liriodendropsis simplex Newberry \\ Myrica longa Heer (?) \\ Myrsine gaudini Lesquereux \\ Protophyllum sp. \\ Protophyllocladus subintegrifolius Lesquereux \\ Rhamnites apiculatus Lesquereux (?) \\ Sassafras acutilobum Lesquereux (?) \\ Widdringtonites reichii (Ettingshausen)
}

Berry comments on these forms, saying "most of the forms have been recorded from the Dakota but a couple have not, and none occur in the Cheyenne sandstone of Kansas. In the Atlantic Coastal Plain the majority are found in beds which I regard as of Turonian age, so there can be no question but that this horizon in Kansas is Upper Cretaceous.".148 The argillaceous material in which the leaves described above are found lies beneath the stream-deposited red ferruginous coarse-grained sandstone but may not be decidedly older than the red sandstones in other localities.

From another locality, in the southeast quarter of section $10, T .16$ S., R. 5 W., Saline county, Kansas, the writer made a small collection of leaves from a cross-bedded coarse-grained ferruginous concretionary sandstone which occupies a position unconformably over

148 Berry, E. W., personal communication, dated Feb. 26, 1925. 
the Comanchean. The relationship appears to be similar to that previously described; that is, the clays and sandstones were cut out and the channels filled with the coarse ferruginous sand. In this particular locality, however, there is no question concerning the age of the lower series, as the presence of the Mentor fauna classifies it as being of Comanchean age. Berry identifies the following forms from the upper sandstone:

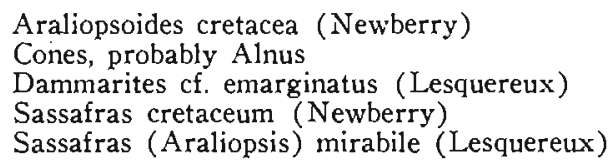

The material from this locality is unquestionably a Dakota flora, ${ }^{\mathbf{1 4 9}}$ which, as defined by Berry, is related to the Woodbine flora of Texas.

Stanton ${ }^{150}$ considers the fossils which he found near Denmark, Lincoln county, Kansas, as showing closer relationship to the upper Dakota fauna of Nebraska than to the Mentor faunas of Kansas. He does not describe the beds from which he collected these fossils and as the writer was not able to duplicate his collection it is uncertain in just what horizon they occur. Rubey and Bass ${ }^{151}$ state, however, that the fossils collected by Stanton in Mitchell and Lincoln counties were found in the beds near the top of the Rocktown member. However, the fact remains that a fauna with Dakota affinities occurs in northern Kansas and that the uppermost beds of the Dakota stage are closely related to the underlying formations, which contain a dicotyledonous flora which Berry believes to be a characteristic Dakota flora. At the same time it must be remembered that the well-cemented coarse-grained sand which occurs in so many localities in northern Kansas generally appears as alluvial deposits filling old valleys and spreading over the previous divides. This condition may indicate an extensive emergence of the lower clays, cross-bedded sandstones and calcareous rocks, followed by a general expansion of rivers of the Platte type over the region of low relief.

Rubey and Bass ${ }^{152}$ explain the upper 125 feet of the Dakota sandstone of Russell county, Kansas, as being a broad stream channel deposit. They give the name "Rocktown Channel Sandstone Member" to this part of the Dakota stage. They also call attention to the inter-

149 Berry, E. W., personal communication, Feb. 26. 1925.

150 Stanton, T. W., Geol. Soc. Amer. Bull., Vol. 23, pp. 255-273, 1922.

151 Rubey, W. W., and Bass, N. W., Kans. Geol. Surv., Bull. 10, p. 63, 1925.

152 Op. cit., pp. 57-63. 
lamination and interfingering of the gray and mottled reddish clay deposits with the coarser-grained highly cross-bedded Rocktown member. This feature is characteristic of the sandstone as observed by the writer, and at the same time he believes that the coarse sandstone interfingers or lenses with other clay beds. Even if the upper part of the Dakota sand is a distinct channel fill the relationship with the underlying formations is very close. The time interval between the emergence of the lower clays and sands and the deposition of the channel sandstone is very short. It is even probable that some parts of the lenses of sandstone which appear as channel deposits but which interfinger with the adjacent clays were deposited in the littoral zone as bars or as fillings in current channels bordering the beach. The normal condition as seen in the outcrop is a channel or depression which was cut in the clays and alternating siltstones and sandstones, filled with the coarser sand to near the top of the channel, and then covered by coarser cross-bedded sands which were spread across the upper surface of the clays. The writer would expect a bar deposit, either littoral or stream channel, to have some relief above the clays or finer contemporaneous deposits and the interfingering beds to slope away from the coarser-grained bar. The lows adjacent to the bars may be filled with fine materials during the closing stages of the bar deposition. A channel fill does not have the relief of the bar and, as indicated, is a deposit made in a depression or eroded channel that is lower than the adjacent deposits and undoubtedly is lower than some contemporaneous deposits made in other parts of the stream channel. In the majority of cases in which the writer has observed the type of deposit described as a channel fill, the slope of the beds was toward the center of the fill and this inclination decreased toward the top as the beds spread laterally.

One of the best examples of a deep erosional channel which was filled by sandstones of the Dakota stage may be seen at the picnic ground called "The Rocks", in sections 13 and 14, T. 19 S., R. 7 W., west of Little River, Rice county, Kansas. The Comanchean series containing the fossiliferous Windom member, cone-in-cone' shale zones, and the Mentor horizon is channeled to a depth of 45 feet and a width of about 1000 feet. In the channel is a deposit of friable, micaceous, medium- to coarse-grained sandstone. The upper 18 to 20 feet is prominently cross-bedded with foresets inclined to the southwest, west and northwest. Many of the truncation planes are marked 
by thin zones of concretions and nodular pebbly materials with clay centers.

One-fourth of a mile west of "The Rocks" a medium-grained light brown to red sandstone shows the continuation of the channel fill. The foresets in the exposures here show inclinations ranging from 15 to 25 degrees predominantly in a west and southwest direction. The approximate limits of the old channel can be followed for almost a mile, and the meandering course has a general west-southwest direction. The upper beds appear to be continuous for several miles and normally overlie the Comanchean series without apparent unconformity.

At a locality about three miles east-southeast of Kanopolis, Ellsworth county, Kansas, in the east bank of Smoky Hill river, near the west side of section 33, T. 15 S., R. 7 W., is an excellent exposure of the dark gray carbonaceous and fissile gypsiferous shales which contain cone-in-cone and are generally characteristic of the Comanchean series. The sandstone horizons are micaceous and contain fragmental plant materials. A deep channel cuts across this section and in the depression there is a medium- to coarse-grained, friable to hard prominently cross-bedded sandstone. The foresets have a general westsouthwest inclination similar to those at "The Rocks", previously described. This is taken to represent the channel fill member of the Dakota stage.

Conditions similar to those described for the Dakota stage were operating in central Kansas during Comanchean time. The Marquette member of the Belvidere formation at the Natural Corral, McPherson county, Kansas, shows a distinct lens character. Zone 9, a part of the Marquette member, is described by Twenhofel" ${ }^{153}$ as "friable, fine grained, yellowish sandstone with a somewhat compact six inch band near the middle and another similar two inch band about 7 feet from the top. Locally the zone contains a little shale. It forms the upper portion of the cliff ábove the spring at the head of the east arm of the Corral, where it is thinner and more compact than indicated above. No fossils. Thickness 17 feet 6 inches."

Figure 31 shows a channel fill by the Marquette member about seven miles west-northwest of the Natural Corral locality. The Mentor horizon lies above this sandstone fill. At many localities near the adjacent corners of Ellsworth, Rice, McPherson and Saline counties 
the Marquette sandstone member is irregularly bedded, lenslike, and fills depression in the underlying beds. This is to be noted particularly in SE. $1 / 4$ sec. 35, T. 18 S., R. 6 W., and NE. I/4 sec. 30, T. 18 S., R. $6 \mathrm{~W}$. , Rice county; SE. $1 / 4$ sec. 6, T. 19 S., R. 5 W., McPherson county; SW. $1 / 4$ sec. 35 , T. 17 S., R. 6 W., Ellsworth county.

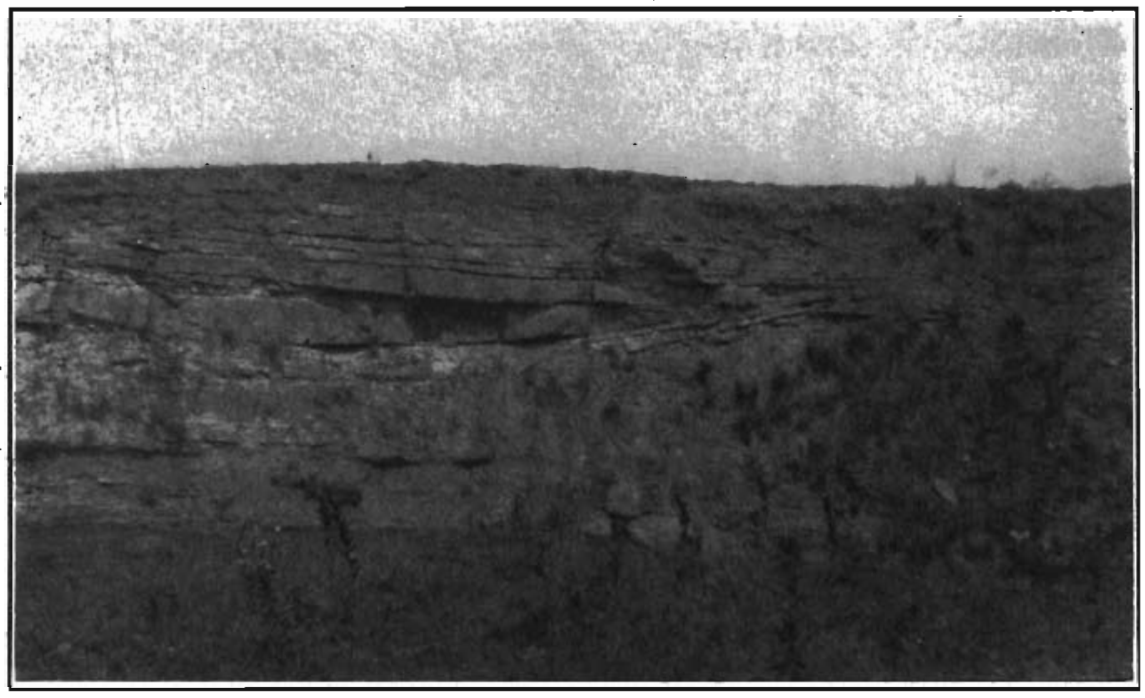

Frg. 31- Erosion of clay and sands of Comanchean age filled by medium-grained evenly bedded sandstone of Marquette member. NE. 1/4 Sec. 29, T. 17 S., R. 6 W., Ellsworth county, Kansas.

A possible exception to the interpretation of the sandstone lenses of the Marquette or Dakota as being channel fills as described in the previous paragraphs may be made in the case of the condition observed near Carneiro, Kansas. In an exposure seen in a road cut on $U$. S. Highway 40-S, in T. 15 S., R. 6 W., one mile west of Carneiro, Ellsworth county, the fine-grained evenly bedded sandstone and gray clays are definitely truncated by erosion and overlain by beds of mediumto coarse-grained reddish brown sandstone. The individual layers of the younger sandstone appear evenly bedded, with the thin parts of the bed pointing toward the clay bank but in detail minutely cross-bedded. The inclination of the units in the younger sandstones conforms to the slope of the truncation surface. Unfortunately, recent erosion has removed much desirable evidence. It is possible that this is merely another channel fill, with the beds sagging toward the center of the channel. However, a short distance to the south another exposure in 
a Union Pacific Railroad cut shows a similar truncation with the beds filling the depression -and gradually flattening to a horizontal position away from the unconformity. About a mile farther south (see figure 32 ) the upper sandstone zones show regular foresets, inclined to west and southwest, with horizontal truncation planes and very thin hori-

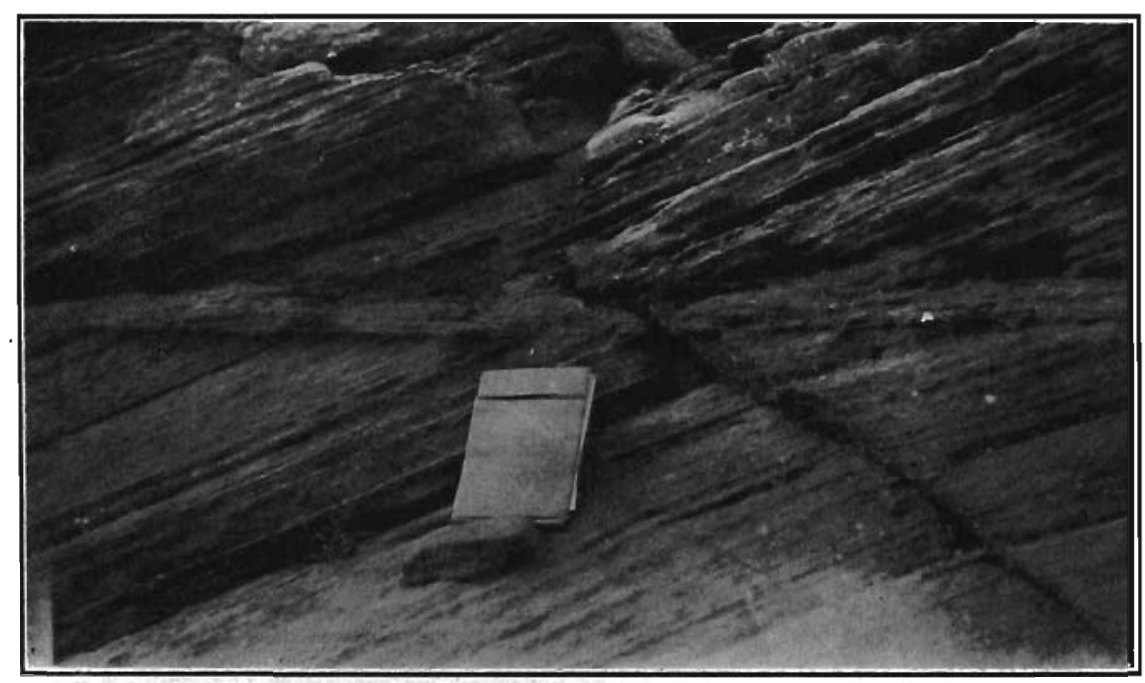
Frc. 32.-Regularly cross bedded sandstone, west of Carneiro, Kansas. Part of delta deposit.
Note book is five by eight inches.

zontal beds separating the foreset zones. This indicates a deltaic deposit, and the writer interprets all the upper beds of this locality as being a part of a large alluvial plain merging with a delta. It is his belief that the younger sandstones seen in the cut on the Federal highway mentioned above belong to a series of long foresets, marking at that time the channel of a delta distributary.

In summary, it appears that the coarse sandstone lenses were deposited in a previously provided low in the clay, silt or sandstone older deposits. In many cases the truncation of the alternating thin sands and clays of the older beds shows clearly that erosion was responsible for the low area or depression. The erosion may have been contemporaneous, due to the shifting and meandering of currents, and could have occurred in a stream channel, at a delta distributary, or in the near shore littoral zone. In other cases, where no erosion is apparent, or where the evidence is not conclusive either way, there are several possible explanations. The depression may have been one due to in- 


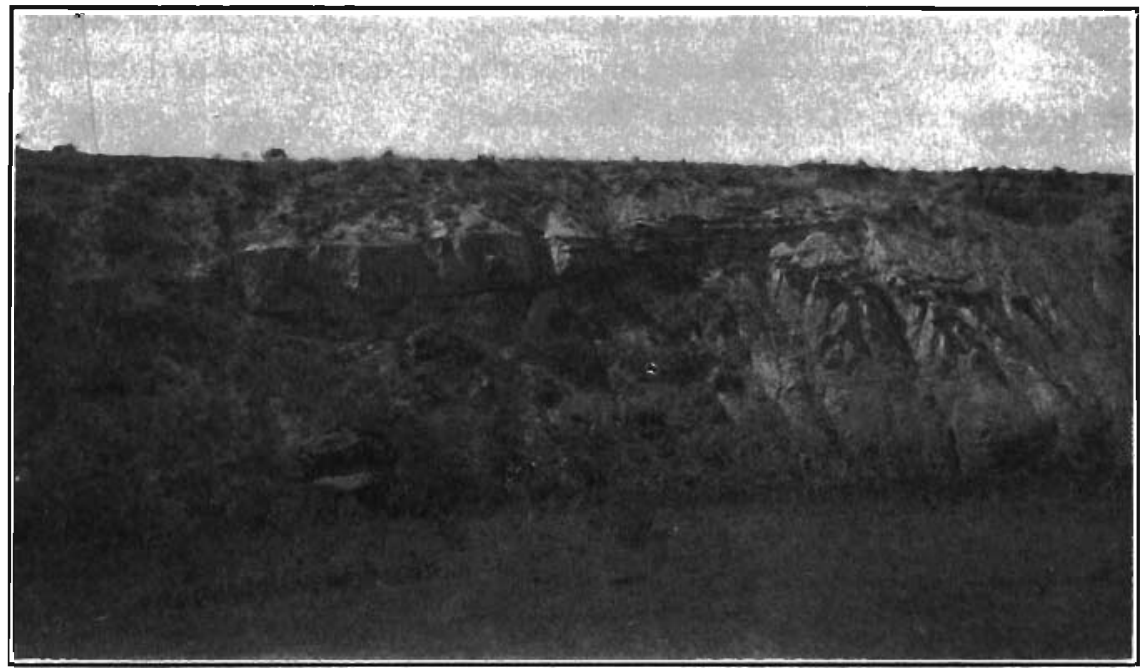

Frc. 33.-Rocktown Channel Sandstone member interfingering with clays and sands of lower members. Sec. 11, T. 13 S., R. 12 W., Russell county, Kansas.

equalities of deposition, or have been a low area lying between two points or projecting fingers of a delta, or a channel-deep in an ordinary fluvial environment; as the new material was brought in by currents, or as the distributaries on the delta shifted their courses, these depressions may have been nilled. In some cases the same current which

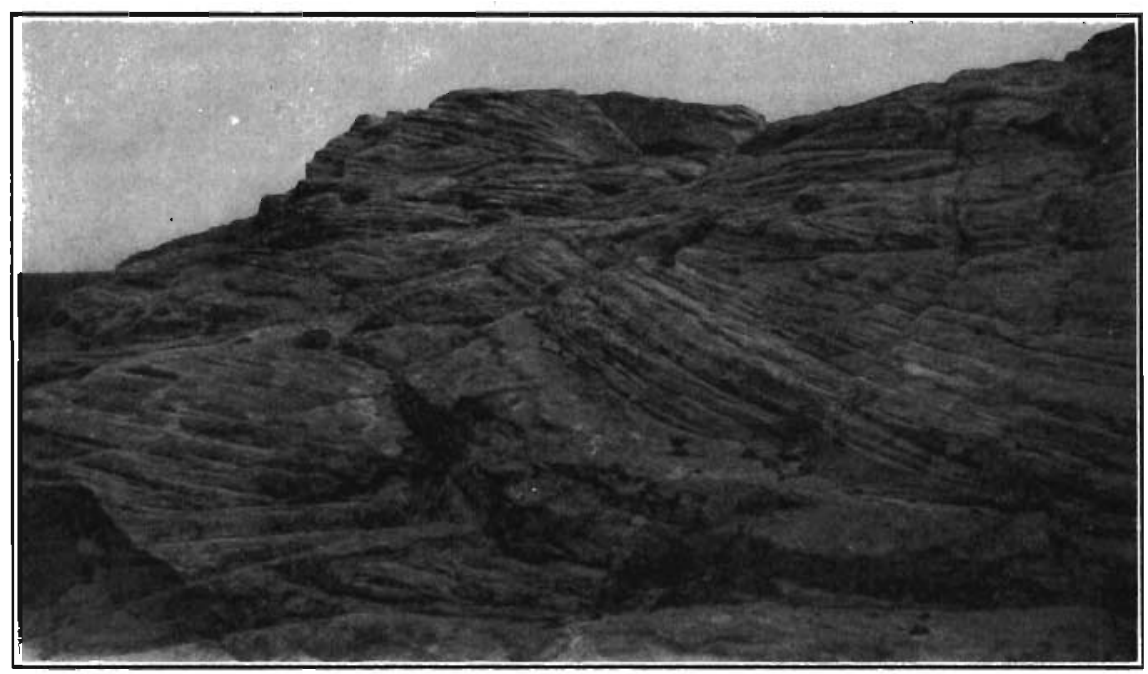

Frg. 34.-The Rocktown Channel Sandstone member in some exposures shows a complexity of cross-bedding. The variety of direction of foresets and truncation planes suggests the average conception of a wind deposit. The field relations indicate the fuvial origin of the beds. SW. 1/4, NW. 1/4, sec. 3, T, 13 S., R. 14 W., Russell county, Kansas. 
brought the material to the site of deposition would rework the higher surfaces, wash some of the clay or silts into the depressions and develop an interfingering of the coarser deposits.

The net result of such interpretation is to yield a series of possible explanations, all of which show a close relationship and a relatively short time break, if any, between the two sets of deposits. Whether the later sandstone series is a stream deposit of rapid alluviation, stream bar, or littoral bar accumulation, the evidence indicates a certain contemporaneity of processes. It is apparent, also, that such conditions began earlier than the Dakota age, as the Marquette member of the Belvidere formation had the same history that has been outlined for the Dakota stage. Marine conditions intervened, however, between the Marquette member and the Dakota stage, as is evidenced by the Mentor member.

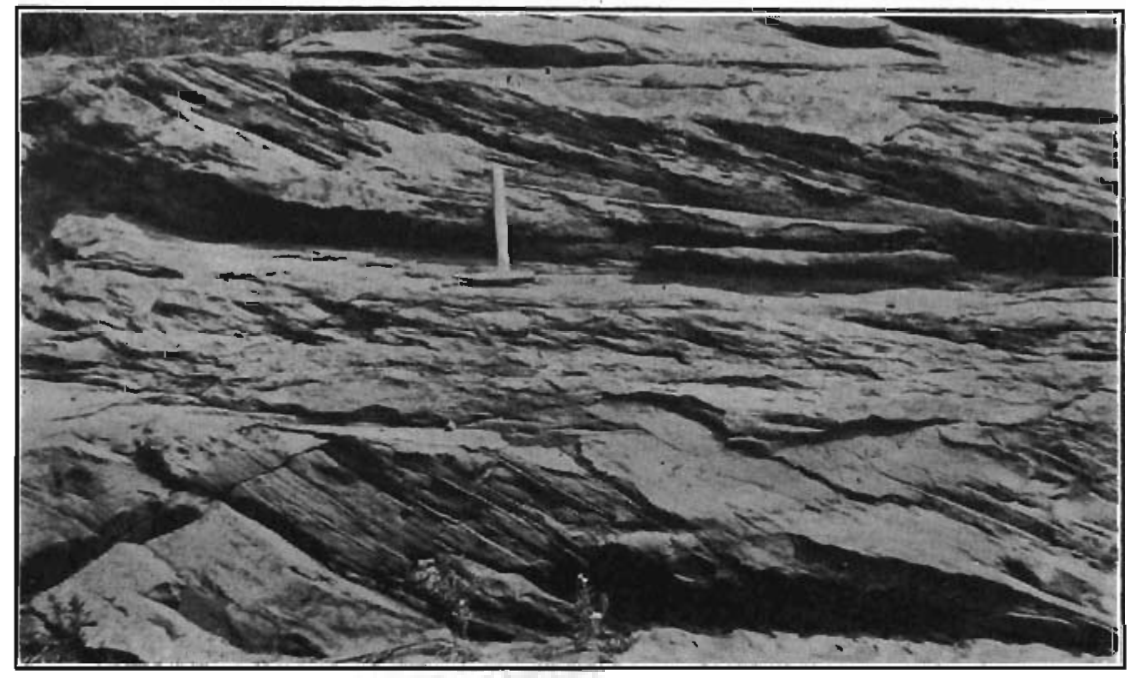

FIG. 35.-In many parts of the Dakota stage closely related to the channel deposits are regular zones of cross-bedding with uniform direction and amount of inclination. Such beds may represent the deltaic phases of the deposits. Sec. 27, T. 15 S., R. 9 W., Ellsworth county, Kansas. 

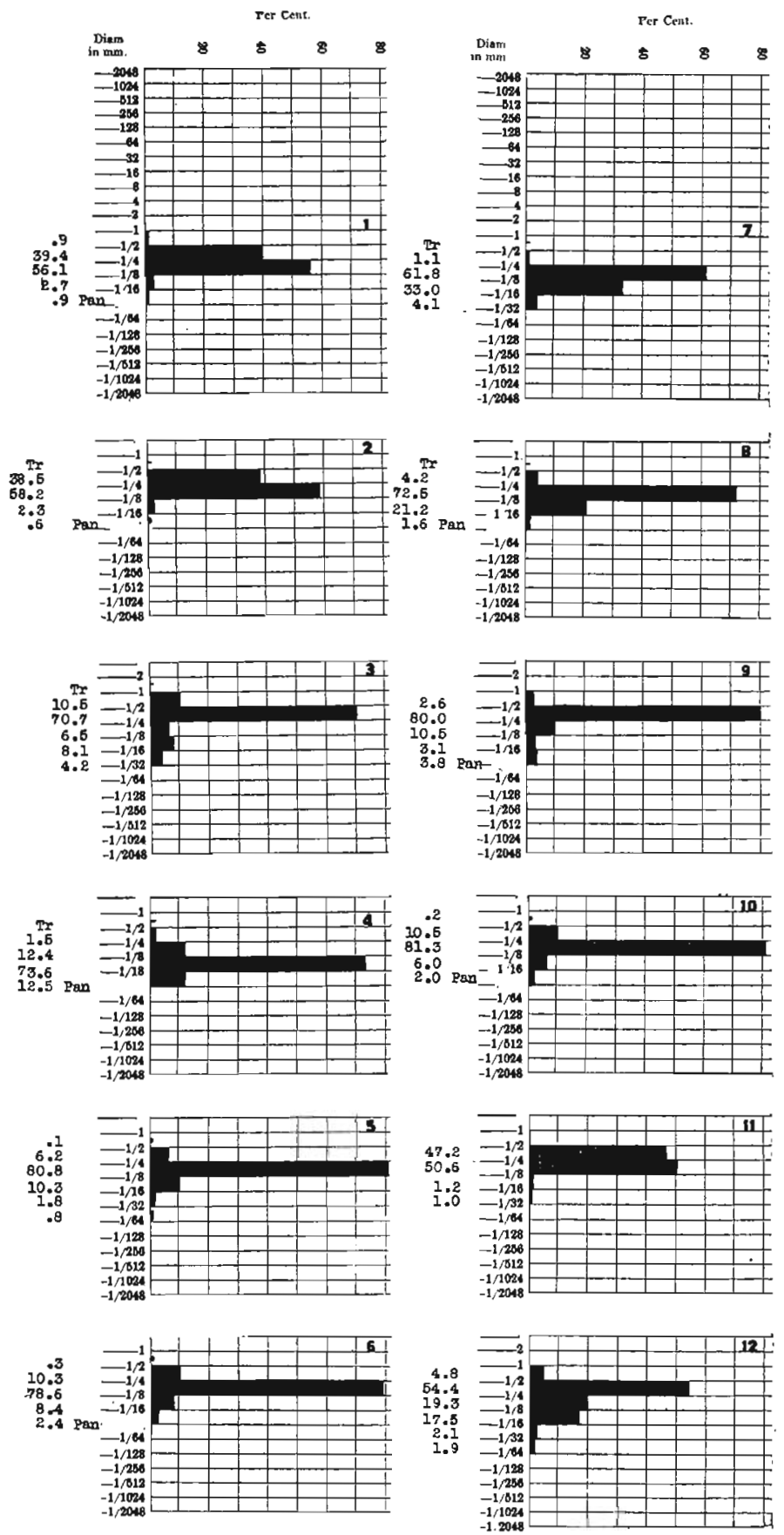

FIGURㅍ 36 
FIG. 36.-MECHANICAL ANALYSES OF DAKOTA SANDSTONE

No. 1. Rocktown sandstone member, Russell county, Kansas. Section 4, T. 13 S., R. 11 W.

No. 2. Dakota channel fill, "The Rocks," section 3, T. 19 S., R. 7 W., west of Little River,

No. 3. Dakota, channel sandstone, southwest Salina, Section 10, T. 16 S., R. 5 W., Saline county, Kansas. Bears leaves identified by Berry as of Dakota age.

No. 4. Dakota, channel deposit interfingering with side of channel. Section 22, T. 12 S., R. 13 W., Russell county, Kansas.

No. 5. Rocktown channel sandstone, near type locality, section 3, T. 13 S., R. 14 W., Russell No. 6. Dakota channel fill, section 33, T. 15 S., R. 7 W., east of Kanopolis, Ellsworth county,

No. 7. Dakota, section 8, T. 31 S., R. 23 W., Clark county, Kansas.

No. 8. Dakota, 15 feet lower than No. 7.

No. 9. Dakota channel sandstone, section 9, T. 13 S., R. 12 W, Russell county, Kansas.

No. 10. Dakota, unconformably above Comanchean, section 31, T. 16 S., R. 3 W., Saline county, Kansas.

No. 11. Dakota, section 4, T. 30 S., R. 18 W., Kiowa county, Kansas.

No. 12. Dakota sandstone, channel deposit, section $8, T$. 19 S., R. 7 W., Rice county, Kansas. 


\section{CHAPTER VII}

\section{INTERPRETATIONS OF THE CONDITIONS OF DEPOSITION OF THE DAKOTA STAGE OF THE TYPE AREA}

In making a review of the detailed stratigraphic sections of the Dakota stage in the type area, adjacent to Sioux City, Iowa, there are several facts which stand out as being significânt to any interpretations which may be made concerning the origin of the rocks.

For convenience, the writer summarizes the most important of the facts which yield to interpretation.

1. The fact that the Dakota stage, as defined by Meek and Hayden and as observed by the writer, is conformable with the overlying calcareous fossiliferous marine shales and sandstones of the Graneros formation. Not only is it impossible to find any break in the section, but it is very difficult to place any arbitrary boundary between the two stratigraphic units. The recurrence of the thin evenly grained micaceous, glauconitic, molluscan-bearing sandstones in the 60 to 100 feet interval of shales between the lignite of the Dakota stage and the chalky limestones of the Greenhorn formation is indicative of the transitory conditions. The writer feels justified, therefore, in making the conclusion that the Dakota and Graneros are intimately related.

2. The presence in zone $6 a$, Section 1 , at the Sioux City clay pits, of a marine molluscan fauna, associated with glauconite, in a part of the section which undoubtedly is a portion of the original Dakota "group" as defined by Meek and Hayden.

3. The presence of glauconite as a primary granular constituent in the sandstones at several levels of the typical section. Zone 6a, Section 1 ; zone 1 , Section 2 ; zones 6,7 and 12 , Section 3 ; zones 4 and 10 (?) of Section 5 ; zone 1, Section 6; zone 4, Section 7 ; and several other scattered positions in isolated sections give typical examples.

4. The presence of dicotyledonous plant material in many of the horizons, some of which contain glauconite, and in the marine molluscan member zone 6a, Section 1. It is true that the zones which contain the best preserved and most complete leaves usually do not contain glauconite. 
5. The occurrence of lignite zones at more than one horizon in the section and at all of the more complete sections of the type area, and the common occurrence of carbonized vegetable material or general lignitic substances in practically every arenaceous horizon in the sections.

6. The characteristic fineness of the majority of the sands, the high degree of sorting, the high angularity of the grains, the low percentage of accessory minerals other than glauconite and muscoviteall these appear as persistent features throughout the area.

7. The abrupt lateral changes in the sands and clays and their tendency to interfinger and to grade vertically are indicative of the delicate equilibrium of the conditions in the site of deposition, which with only a slight variation would change the character of the material deposited. This fact also makes it very difficult, and it might be said undesirable, to attempt any detailed correlation, zone' for zone, between the different sections of the type area.

8. The presence in various sandstone zones of marks which may be interpreted as oscillation ripples, wave or swash marks, also the concentration of iron oxide in thin zones, many of which are parallel with ripple surfaces, truncation planes and foreset zones; all indicate the relative shallowness of the water and the possible occurrence of short periods of emergence.

9. The presence in several of the sandstone members of minor unconformities or diastems but the absence of any marked erosional channels similar to these described in the Kansas section.

10. With the exception of the significance of the mineral glauconite in several of the sandstone zones of the sections in the type locality, a study of the mineral content of the sands yields very little information. Numerous photomicrographs showing the physical nature of the sands, the glauconite and the cementing materials of the sand, and enumeration of the minerals in some of the specimens have been included as part of the detailed descriptions. Mention has been made frequently of the presence of grains of quartzite and chert of varying sizes, of basic feldspars and amphiboles, which is taken to be an indication that the sands of the Dakota type area had, at least in part, their source to the north and northeast. In southeastern South Dakota and adjacent Minnesota, about 80 miles north of Sioux City, the Sioux quartzite of Algonkian age was exposed during Cretaceous time, as is indicated 
by the condition of overlap observed in the field and interpreted in well records. The relative abundance of basic feldspars may have a close correlation with the numerous exposures of diabase dikes in the southeast corner of South Dakota. The presence of a variety of minerals such as zircon, tourmaline, ilmenite, magnetite and rutile means little as they occur in varying quantities at different localities and are generally distributed through sediments of different ages.

At first the writer was skeptical concerning the validity of his identification of the mineral glauconite, but comparison with sections and grains of the same mineral in various stages of decomposition from sediments in Kansas, New Jersey, Texas and Wisconsin served as a check on the identification of the mineral in the Dakota type sands. There seems to be little question that the glauconite in the several members of the Dakota stage was formed on the site of deposition of the sand. In one or two instances, however, the evidence is not so certain, and it is possible that a few grains of weathered glauconite which were observed in some of the lower sands of the Sergeant Bluff Section 5 and the Homer, Nebraska, Section 10 were derived by the erosion of a nearby glauconitic sandstone. The mineral is so fragile and easily weathered that it is doubtful if it could stand a very long period of transportation. The writer knows of no fresh glauconite which occurs in rocks of other than marine origin. Glauconite sometimes develops by the alteration of an alkaline feldspar, but such development can be observed when the grain is studied in thin section. Such alteration was observed by the writer in a thin section taken from zone 9 of Section 1, which is at the top of the Dakota or base of the Graneros formation.

It is difficult to make correlations of the individual zones represented in the different detailed sections presented in this paper. As appears in the study of any single exposure the lensing and interfingering of different types of rock are pronounced, and it is even difficult to compare two sections within a few hundred feet of each other, except by noting the position relative to a given datum. Thus the lack of any persistent horizon makes it unwise to attempt a detailed matching of the sections.

It has already been shown that it is undesirable to attempt to use the contact between the base of the Graneros and the top of the Dakota as a means of correlation, as this zone does not have a definite 
position. Any division between the Dakota and Graneros is purely arbitrary, and the writer believes that such a division is unnecessary. Observations in the Kansas area substantiate this conclusion. At many places where a section includes the Dakota and Graneros, the former grades into the latter. It is true that the Graneros shales are almost everywhere dark gray, carbonaceous, fissile, with sandstone lenses, and have a few invertebrate fossils which are more distinctive of the Colorado stage.

The base of the Dakota stage in the type area is not exposed, and it is uncertain from a study of the poorly preserved well records just where it may be. Indications are, however, that the Dakota ranges from 100 to 300 feet in depth below the surface in the type area. It is interesting to note, however, that wherever the Dakota is found resting on older rocks, the interval to the overlying Graneros is normally much less than the figure of 400 feet which is frequently given for the Dakota of Nebraska, Kansas and Iowa. The writer is of the opinion that when more careful records are taken and a thorough study is made of the well cuttings from drilling's which penetrate the full division of the Dakota in northern Kansas and Nebraska the average thickness will be found to be approximately 225 to 250 feet. The occurrence of 50 to 100 feet of sandstone and interbedded shales in one locality, 100 or more feet of clays and silts in another locality, with 50 to 100 feet of sandstone overlying the clay in several cases, has led some geologists to believe that the Dakota is divisible into three members, and that the thickness is the total of the three divisions. The writer's observations, as has been indicated in the present paper; cause him to be strongly of the opinion that the clay zones are frequently the equivalent of the sandstone zones, either the so-called upper or the lower sandstone.

The general change in the character of the deposits from one point to another may be appreciated by comparing the writer's Sections 10 , $8,7,5,4,1,2$ and 3 (see Fig. 25). This series of sections starts southwest of Homer, Nebraska, takes in the west bluff of Missouri river to the Aowa creek section, the east bluff of the Missouri from Sergeant Bluff north through the Sioux City pits to the section in southern Plymouth county on Big Sioux river. The differences in sections when considered as a whole show the dominance of sandstone in the south and as far as the Prospect Hill section at Sioux City, with 
finer grained and more argillaceous beds to the north and west, as seen in the Aowa creek section 7, the Stone Park Section 2, and the Plymouth county Section 3. The upper part of the Sergeant Bluff Section 5 is dominantly sandy, while the lower portion contains a large amount of shale, clay and silt.

The only factors which might be termed consistent in any of these sections are the lignite beds as seen at Sergeant Bluff and the Sioux City pit, and the reddish brown glauconitic 20- to 24inch sandstone layer which can be traced from Sergeant Bluff to the Sioux City pit, thence to Stone Park and to the section in southern Plymouth county. At the base of the section along the south bank of Missouri river, zone 1 of the Elk Point Ferry Section 6 contains the marine fossil horizon and glauconite, as described above. Zones 4 and 5 of Section 7 and the top zone of Section 10 south of Homer probably are equivalent to this sandstone. As this is the member which carries the marine invertebrates at the Sioux City pit, the belief is that at this one period at least an embayment occurred in the Sioux City area.

The lignite which occurs in zone 9 of the Crill Mill section of southern Plymouth county may be the same as zone 7 of the Stone Park Section 2, which in turn may be near the same position as the lignite of zone 5, Section 7, near the mouth of Aowa creek. This lignite lies at the base of zone 7 , Section 2, and below zone 1.2, Section 5 , either of which the writer believes is correlative with zone $6 \mathrm{a}$ of Section 1. As seen in Sections 1, 3 and 5 there are lower lignite horizons which may be at about the same position. In Section 7, at the mouth of Aowa creek, there is a higher lignite which does not seem to have any correlative in the other sections.

The presence of the lignites low in the stratigraphic section, again in the middle of the sections, and in one case in the upper part of the section, and the large amount of lignitized and carbonized vegetable material which occurs in large fragments and as small accumulations in depressions in the sandstone and silt in many parts of the exposures indicate the recurrence of swamp or lagoon conditions favorable to the accumulation of vegetable material under water. The presence of a fine-grained sandstone with glauconite, and, in at least two localities, with marine invertebrates, indicates a marine extension at least once during the Dakota age. The occurrence of glauconite in the various 
sands is taken as proof of their marine origin. It is true that a glauconitic sandstone at one point, as for instance at Aowa creek, may have for its equivalent a series of alternating fine sands and silts at another locality, as at Homer.

The section at the foot of Prospect Hill in Sioux City, with its dicotyledonous flora, and the sandstone zones which carry the same type of leaves at Sergeant Bluff, the Sioux City pit, and along Big Sioux river do not necessarily prove the terrestrial origin of the sediments. The occurrence of some well preserved leaves suggests, however, that land was not far removed and that at favorable times the leaves floated out to be deposited in the lagoonal and deltaic sites of accumulation.

The direction of the motion of the currents which were depositing the sands in the type area may be interpreted in part by the direction of inclination of the foreset beds of the cross-bedded zones. Such inclinations have a wide range and may be found facing the southwest, west, north and northeast. This would leave the southeasterly and a part of the northeasterly quadrants as possible directions from which the transporting currents came. When the sections southeast of Homer and southward toward Decatur are considered, the direction of the inclination of the foresets is seen to change to face the southwestward and southeastward quadrants, thus suggesting a swinging of the shore line toward the southeast in the area southeast of Sioux City.

In sumning up these statements and interpretations the writer concludes that the type area of the Dakota stage represents the sediments laid down in an environment at and near the shore line of a broad, relatively shallow ocean. The material was derived from the north and northeast and was carried southward by streams of small competency which may have had wide flood plains and which when reaching the coast line built wide and ramifying deltas. At times these deltas extended themselves seaward with a development of barlike fingers of relatively coarse material, with the minor distributaries of the streams throwing off the finer silt and clays which were deposited on the flank of the principal distributary. Such a finger is believed to occur in the north-south zone which is indicated by the Prospect Hill and Homer sections. During at least one time the sea advanced over the deltaic and littoral deposits to and probably beyond the Sioux City 
area and deposited a glauconite sand with marine invertebrates. That the sea advanced from the west, southwest and south in this area is indicated by the direction of the foresets in the accompanying current deposits. How far south this sea extended the writer is uncertain. However, the fact that the marine invertebrates at Sioux City show close relations to parts of the fauna of the Mentor formation of Kansas indicates that there was a common source of the fauna and that the seas were at least connected. The writer has been inclined to believe that the Sioux City sea was not continuous into southern Nebraska and central Kansas, but that possibly a peninsula projected westward from southern Iowa into central Nebraska and separated central Kansas from the northwéstern Iowa embayments. In this case the principal advance of the sea in the Sioux City area would be from the west and southwest, and the gulf would have a shore line which would trend to the southeast from Sioux City and swing westward from southern Iowa into central Nebraska. The coarse deposits of the Coburg, Lewis and other southwestern Iowa localities represent the deposition of the westward- and southwestward-flowing streams. These streams made their deposits and extended their deltas for a short period over the thin marine bed represented by zone $6 \mathrm{a}$ of Section 1 . A second definite sea invasion followed which marked the beginning of the conditions which were ultimately to characterize the Graneros, Greenhorn, Carlile and Niobrara deposits.

The brief descriptions and references to the Dakota of southern Nebraska and central Kansas were included to show that the deposits of those regions have some characteristics in common with the Dakota stage of the type locality and also show some marked differences. However, there is no question in the writer's mind but that the history of the Cretaceous rocks below the Graneros of Kansas, when considered in a single picture, represents conditions which were not unlike those of the Dakota of the upper Missouri country. That is to say, a near shore, littoral, marine and terrestrial environment existed in Kansas, and coarse sand, silts and clays and lignites were deposited in that environment; but it occurred at an earlier time than the deposition of similar sediments in a similar environment in the Sioux City area.

Twenhofel ${ }^{104}$ has shown that the Kansas sediments of this type include several members which carry a marine fauna of a definite age

154 Twenhofel, Kans. Geol. Surv., Bull. 9, 1924. 
The equivalency of this fauna to the Washita of Texas has been established. At the same time the age of the youngest part of the Dakota stage of Kansas appears to be that of the type Dakota, based on the floral content.

Whether the shore line on the eastern edge of the Dakota embayment had a direct course from eastern Kansas to midwestern Iowa, or whether it curved northwestward from eastern Kansas to central Nebraska around the peninsula and then curved back to the east in western Nebraska, extending on up into Minnesota, the fact remains that the accumulation of the Dakota type sediments was made at about the same time as the accumulation of the Belvidere formation and the delta and river deposits of the Dakota of Kansas.

The writer favors the theory of the contemporaneity of the type Dakota and the Dakota and Belvidere of Kansas, rather than the theory of a progressive overlap from Kansas northward to Nebraska. It would have been impossible for the latter condition to occur with the deposition of sands by streams in Kansas at a time when a glauconitic sandstone was being accumulated in a marine environment in Nebraska; the close relationship of age being established by the dicotyledonous flora and also by the close affinities of the invertebrate faunas. Another viewpoint might be taken by considering the Graneros and Greenhorn formations. In Nebraska and northwestern Iowa the Graneros formation is merely a transition from the Dakota, and there is small difference in the relative ages of the two, as indicated by the affinities of the pelecypods in the glauconitic sand layers in the gray shales at the base of the Graneros. In Kansas the Graneros overlies the Dakota with apparent conformity and is also a transitional sediment. Where the Graneros occurs above the Rocktown Channel Sandstone member the only break or apparent unconformity, except the gradual change in lithology, is found at the base of the Rocktown member. If this nearly continuous deposit represented an accumulation in a gradually advancing and overlapping sea, the deposits of the southern area should be much older than those of the northern area. This does not appear to be true; first, because of the presence of a similar dicotyledonous flora in both areas; second, because of the presence at Sioux City of marine invertebrates which are closely related to the invertebrates contained in the Mentor member and in a sandstone at the top of the Dakota stage of central Kansas and in the formation just below and closely 
related to the Rocktown member of Kansas. There may have been in early Graneros time an overlap of a rapid nature which moved toward the southern and northern area simultaneously from the west. This possibility is suggested by the character of the deposits, the direction of inclination of the foresets, and the extent of the channel deposits of the Dakota stage of Kansas and northeastern Nebraska. However, the writer has not made sufficient studies in the areas west of Kansas and Nebraska to discuss this viervpoint.

\section{The Position of the Dakota Stage in the Upper Mesozoic Sequence}

The primary purpose of this paper is not to define the relations between the rocks which have been called Comanchean and sometimes included as a separate geologic system, or to argue the question of the validity of the division of the Cretaceous of central North America into two systems. However, certain facts and relationships concerning this question may be gained from the data presented in this paper. Other data which the writer has accumulated and has not presented here, because of the limits of this work, also serve as a basis for the writer's opinion.

Using the Kansas, Nebraska and western Iowa area as a background, the writer is convinced that the Washita-Kiowa-Mentor series belongs to the same general sequence as the Dakota stage of the type area. Also, because of the close relationships and the similar physical history of the "Dakota" (using the term in a narrow sense) rocks of Kansas and the Kiowa-Mentor series of Kansas, it seems impractical to make a systematic separation in that part of the geologic column.

The affinities of the fauna which occurs in the rocks of the type section with that described by Stanton from the Dakota sandstone in northcentral Kansas and in turn with some of the species of the Mentor sandstone of central Kansas, and the occurrence of typical Dakota flora in the clays which lie below the channel member of the Dakota in Kansas and are closely related to the Belvidere clays and sands, all tend to substantiate the conclusion that the entire section is too intimately related to bear a major geologic division.

The writer places the Washita-Kiowa-Mentor-"Dakota" rocks of 
Kansas in a stage at the base of the Cretaceous system. This stage may be considered a part of the Comanche series. The Dakota of the type area may be in part younger than the oldest part of the stage in southern Kansas and younger than the lower part of the Comanche series of Texas; it is at least as old as the Mentor member of Kansas, and apparently is closely equivalent to the entire Kansas section. 


\section{CHAPTER VIII}

\section{AN EXPERIMENTAL STUDY OF FLUVIAL SORTING AND DEPOSITION}

The question of how to sample a sedimentary rock for analysis is difficult to answer. Also, it is difficult to be certain if the sample is representative of the conditions under which the material was de-

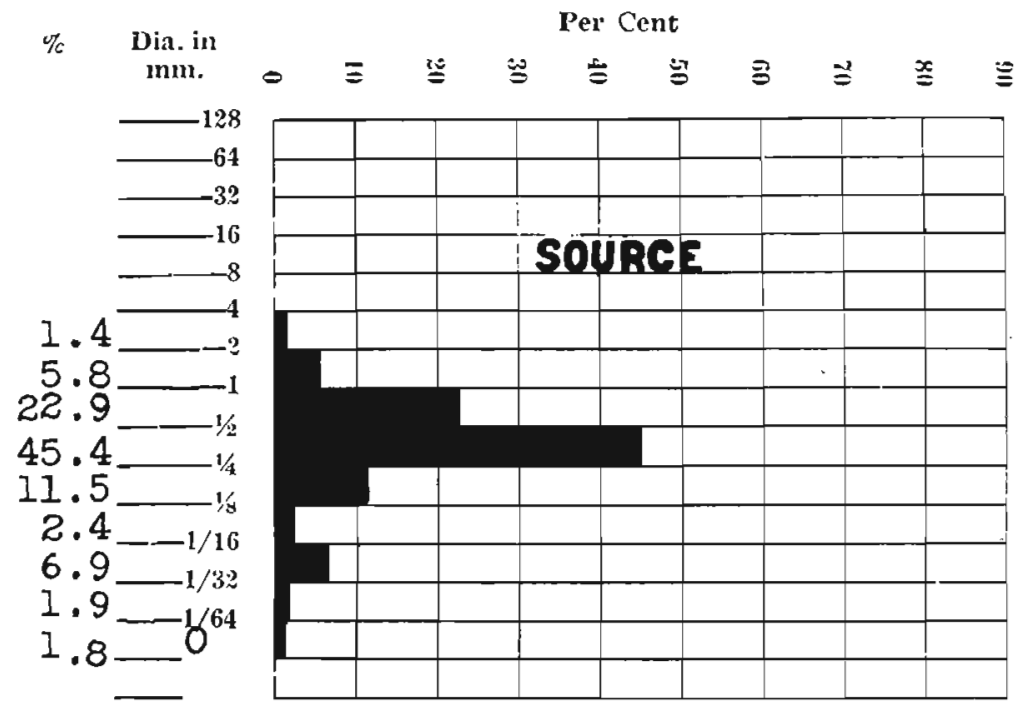

Fic. 37.-Analysis of source material for Experiment No. I.

posited. In dealing with cross-bedded sandstones one can take many different types of samples. A sample taken from a vertical zone at right angles to the direction of the depositing current and a sample from the same position but parallel to the current may show some differences;

The experiments described in this chapter were performed in the spring of 1929. Since that time a new stream table has been installed in the sedimentation laboratory. The new table is built of sheet steel, rigidly supported by heavy steel beams mounted on capstan jacks. The tank is 21 feet long, 7 feet wide, with sides 12 inches high at the low end. The steel trough is joined with a depositional basin 7 feet wide by 8 feet long and 2 feet deep which has glass sides and a concrete floor. The jacks serve to change the gradient, with a flow either to or from the depositional basin.-March, 1931. 
a sample taken from a single layer or foreset zone may be distinctly different from a sample which represents a composite of several or all of the foreset zones of a single unit of cross-laminated beds. Samples taken from different parts of river channel and bar deposits show different types of mechanical analyses.

In order to study the variety of analyses obtained under known con-

TABLE I

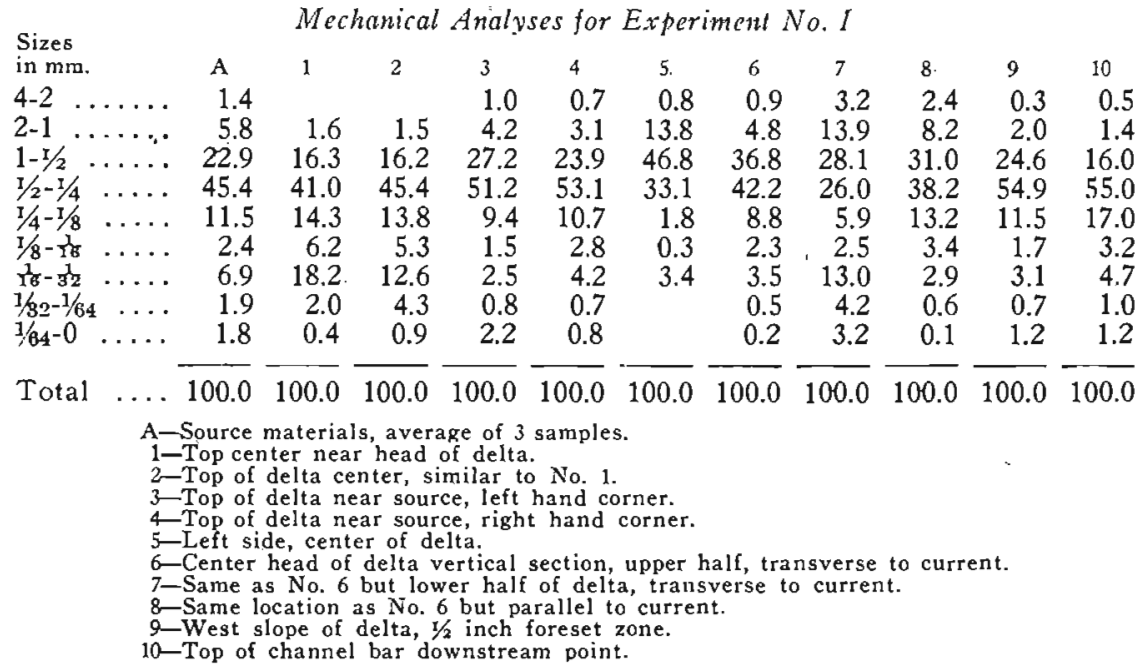

ditions of river transportation and deposition, the writer performed some simple experiments with the stream table in the sedimentation laboratory at the University of Iowa.

The stream table used for these experiments is a long, shallow, flat bottomed, horizontal trough, measuring 13 feet long, 3 feet wide and 7 inches deep. The trough is lined with sheet tin and is water tight. The bottom of the trough is horizontal and relatively even, except for a few minor bulges in the tin work. At one end is a basin with an outlet which can be changed to maintain a constant water level at different depths in the trough. The water enters the table as a spray or from a lakelike reservoir at the end opposite the outlet.

STREAM TABLE EXPERIMENT NO. I

The upper half of the table was filled with sand so as to make a bed over which the water would flow from the reservoir at the head. The crude channel prepared in the sand had a very steep gradient with an abrupt reduction at the edge of the sand bed. The outlet level was 


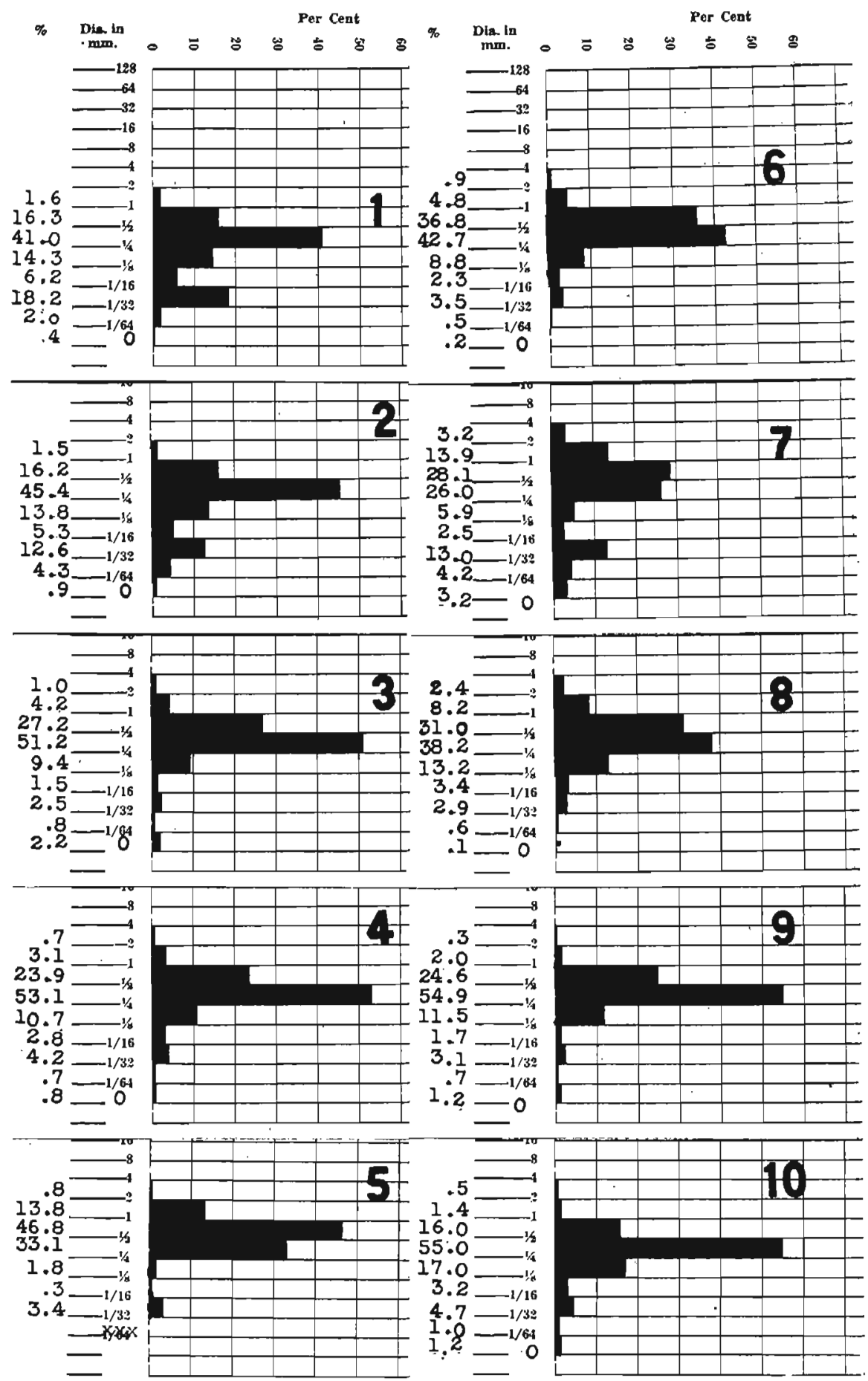

Frc. 38.-Mechanical analyses of deposits in Experiment I. See Table I for explanation. 
raised so that approximately $31 / 2$ inches of water stood in the table below the sand bed area. The effect was a rapidly flowing stream carrying a heavy load which was deposited on the growing delta. The delta was approximately 12 inches across and 16 inches long when it was completed and the samples were taken. A number of samples taken from various parts of this delta were analyzed and compared with the analysis of the sand being eroded.

The analyses in Table I and plotted on figures 37 and 38 speak for themselves. There are important differences in the deposits as indicated by the graphs, even after the minor distinctions are eliminated by the use of a small plotting scale.

Samples 1 and 2 are similar and were taken from nearly the same position and from environments also identical. The analyses of these two sediments show that under similar conditions a similar assortment of sand is deposited.

Analyses 6, 7 and 8 make an interesting comparison. Numbers 6 and 7 are from a vertical zone which was transverse to the direction of the depositing current, but number 6 represents a zone $11 / 2$ inches deep, including the top, and number 7 is a one-inch section immediately below. The difference in the analysis includes a shift of the primary or maximum grade from the usual one-half to one-fourth $\mathrm{mm}$. grade in number 6 to the $1-\mathrm{T} / 2 \mathrm{~mm}$. grade in number 7 . In general number 7 is a coarser sand with over three times as much material in the two coarser grades and with the maximum grade occurring in the $1-1 / 2 \mathrm{~mm}$. grade. However, number 6 has 85 per cent of its material larger than $\mathrm{I} / 4 \mathrm{~mm}$. and number 7 has only 71 per cent in the same range. Number 7 differs also in the prominent secondary maximum in the $1 / 16-1 / 32$ mm. grade.

In the case of samples numbers 6 and 8 the specimens were taken from nearly the same position with regard to the head of the delta and represent a vertical section $1 / 2$ inches deep, including the top. Number 6 sample came from a face one inch wide transverse to the current direction, and number 8 came from a face two inches wide and parallel with the current. The differences in these analyses are very slight, the small increase of material in the finer grades below $1 / 8 \mathrm{~mm}$. in sample 8 being due probably to the slightly greater distance from the source of a part of the sample.

Samples 3 and 4 show similarities in their size composition. The 
positions on the delta with regard to source and depth of sampling were nearly the same except that they were from opposite sides and were deposited by different distributaries.

Sample 9 is from a thin zone of foresets and was taken parallel with the bedding. It is probably more distinctive of a single set of conditions than any other sample of the group. The current and volume of the distributary were nearly constant during the deposition of this single foreset bed. The degree of assortment of the sand is shown by the presence of 55 per cent of the entire sample in the $1 / 2-1 / 4 \mathrm{~mm}$. grade and 79 per cent in the grades between $1 \mathrm{~mm}$. and $1 / 4 \mathrm{~mm}$. There is a close similarity to sample 4 , which is from the top of the delta and in reality represents the material in process of transportation to a foreset zone at the time the water current was shut off. Sample 10 is of a different type than those described above. It is from the stream side of the downstream point of a bar in the channel above the delta. The analysis when compared with that of the source material shows the effect of a sorting action with a concentration of a greater amount of material in the $1 / 2-1 / 4 \mathrm{~mm}$. grade and the removal of the coarser grades. The subsidiary grade of $1 / 4-1 / 8 \mathrm{~mm}$. is greater in the case of the bar deposits than in the source material.

In summary, it appears that some caution should be exercised in taking samples and that careful note should be made with regard to the structural relations of each sample. This is true particularly in the case of foreset beds. It is not always possible to know the exact relationship of any specimen to the head of a delta or to the distance from the farthest removed distributary, but it appears from these analyses that these facts are less important in the ultimate interpretation.

The statement of this experiment does not intend to exclude the facts that the conditions represented here on a small scale do not exactly duplicate the natural environments and that conclusions drawn from such experiments may differ from conclusions based upon accurate observations in nature. However, such experiments do tend to demonstrate the need for more measurements of natural conditions.

STREAM TABLE EXPERIMENT NO. II

The sand material used for this experiment was spread out more or less unevenly over the stream table with a gradual decrease in thickness from the head of the table to the foot or the basin end. At the 
head the sand was approximately eight to nine inches deep, while at the foot there was only about one-half inch of material. A broad, indistinct meandering channel was made in this sand bed, so that as the water flowed from the reservoir at the head there was a tendency for it to follow in this lower course. In other words, a consequent stream was developed.

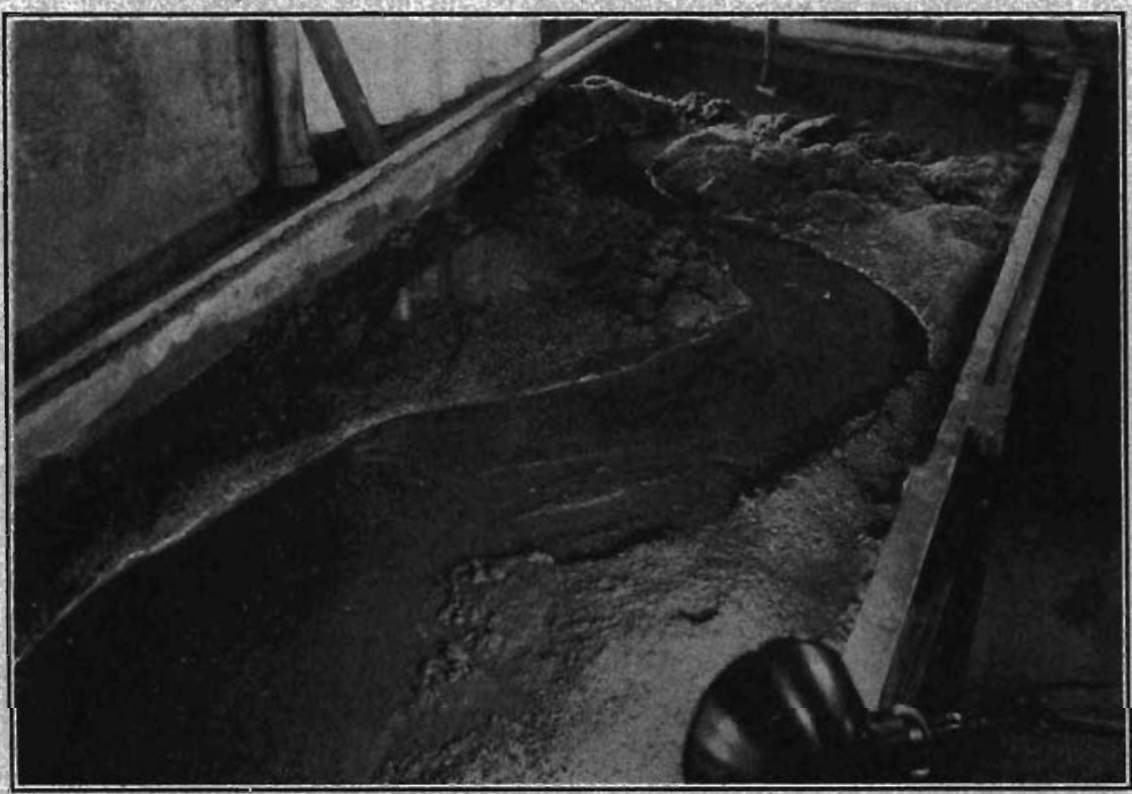

FrG. 39.-A view of the river taken at an early stage of Experiment II, before cutting through the bank on the right midale and left background, Compare with Figure 40 .

The water was allowed to flow continuotisly for nearly one hundred hours, during which time the stream meandered, changed its course, built and removed bars, and in general developed a flood plain similar to that seen in rivers of the Platte river type. Figure 39 shows an early stage of the stream on the upper half of the table. It will be noted that the water is very shallow and that in reality there is considerable tendency for the braiding of the channel. Figure 40 shows the stream table with well developed channels at the close of the experiment. This view was taken from about five feet above the table and the background is considerably foreshortened.

Figure 40 shows the position of a series of samples which were taken to represent the different types and conditions of the stream deposits. Additional explanations are given in the following pages. 


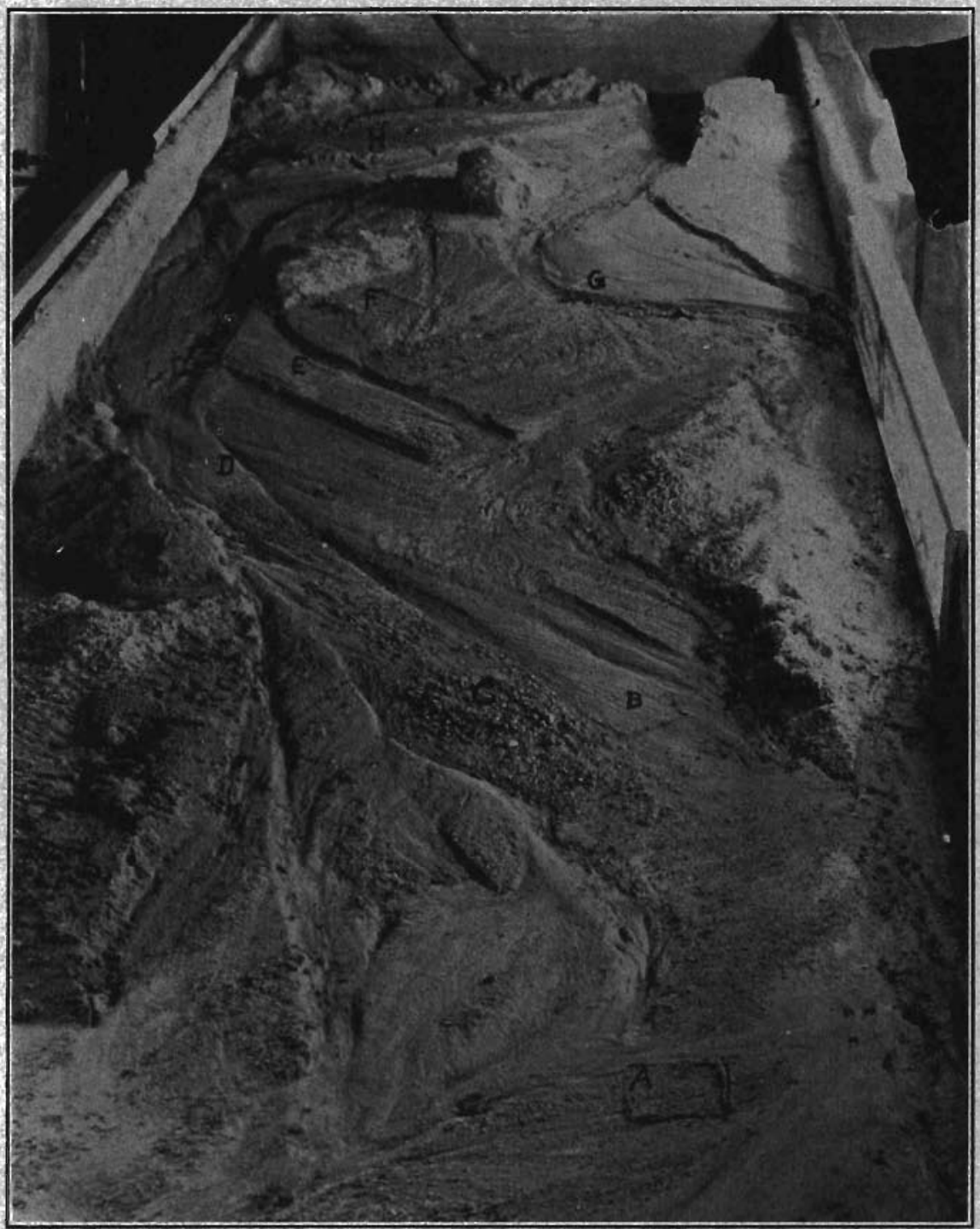

FIG. 40.-View taken from basin end and about five feet above stream table, showing all parts of stream and location of samples.

Figure 41 shows in greater detail the character and position of samples B, C, D and E. The analyses of these samples are grouped in figure 42 , and the percentages are tabulated in Table II.

All samples were taken from an area approximately two inches square and included the material in the upper one-fourth to three- 
eighths of an inch. Samples were dried and analyzed for both their sand and clay content. The regular method of subsidation and screening is described in Appendix A.

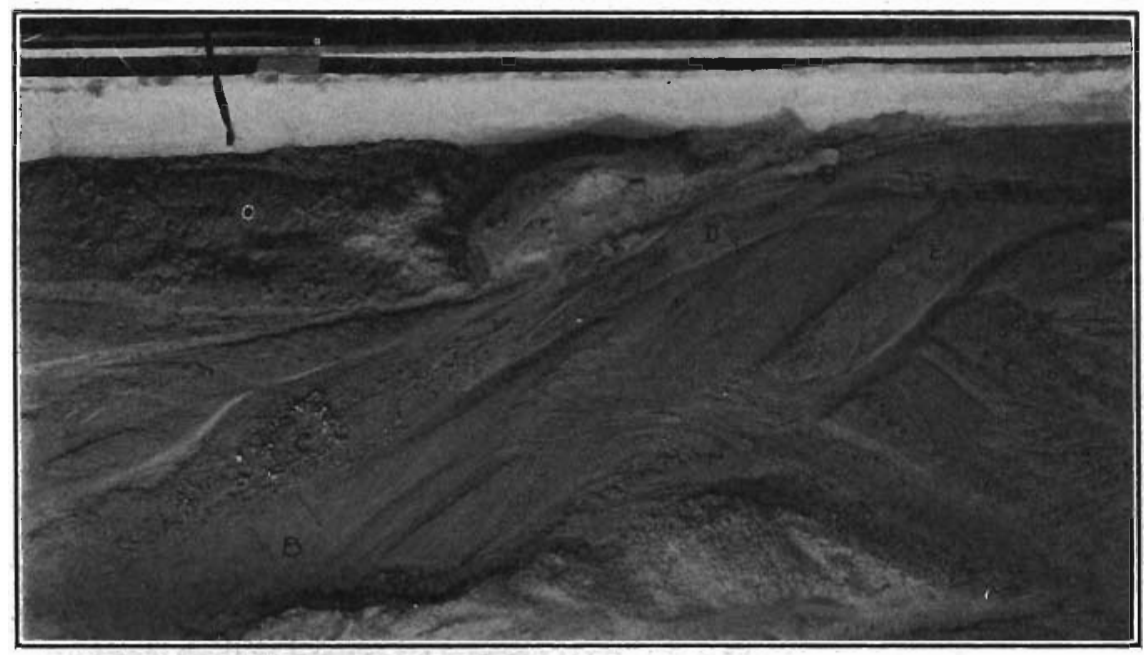

Frc. 41.-Detailed view of central part of stream showing position of samples B, C, D and E.

Sample A.-Taken near the basin end of the stream table from a part of the channel which received only a side current, which at times of overflow would have a trend of 60 to 75 degrees to the right of the main current. Fine material would be deposited over the coarse, tending to settle between the coarse grains. In the photograph the coarse grains are more apparent.

TABLE II

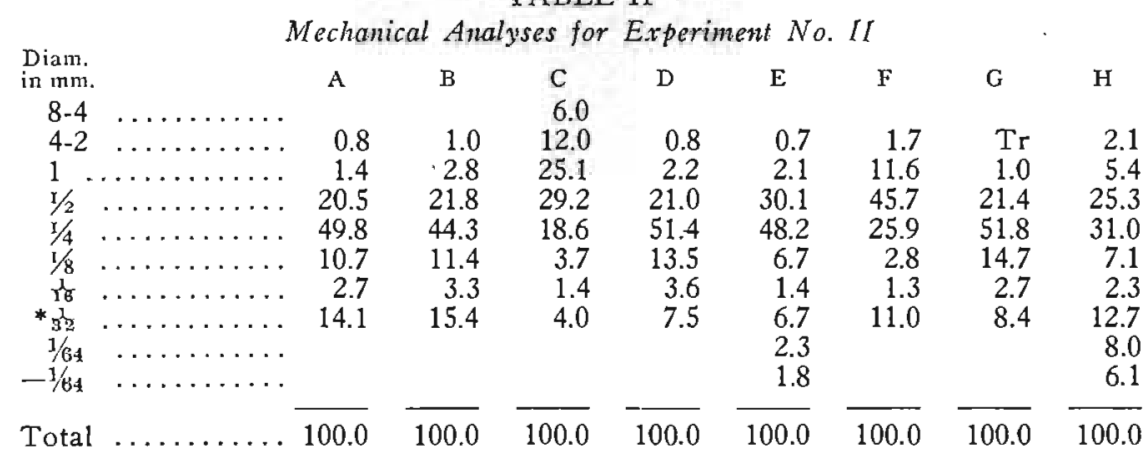

* In the analyses which do not show percentages below the $1 / 32 \mathrm{~mm}$. grade no separation was made and all that passed the $1 / 16 \mathrm{~mm}$. screen was caught in the pan. 
Sample B.-Taken from a bar in the main channel on the left side of the main current. The angle between the main and bar currents was about 25 to 30 degrees. In the photograph, figure 40 , the material

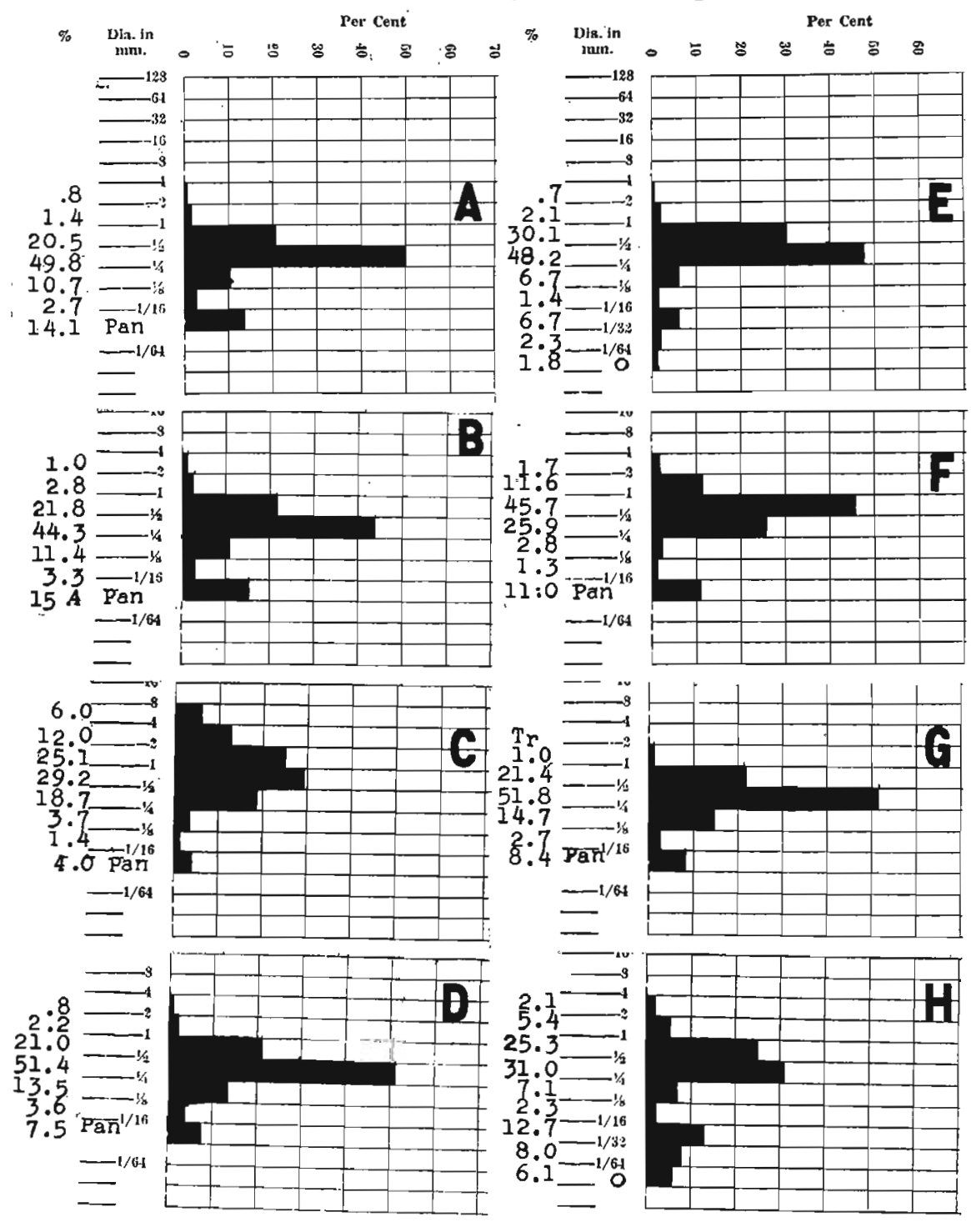

Frg. 42.-Mechanical analyses of deposits in Experiment II.

appears finer than that of sample $A$, but the analysis shows that it is slightly coarser. Sample $B$ included a part of the coarse-grained bar nucleus which had been covered with the finer sands. 
Sample C.-Taken to the right of B but in the main charne!. The material in the stream bed grades downward to finer sand which was deposited when the main current was near the right hand bank.

Sample $D$.- A bar sample from the last principal channel about midway in the length of the stream. Just below this sample at the point of the bar the sand was much coarser. The coarse material was carried along the edge and over the top surface of the bar. Sands of a more typical size grade distribution gradually migrated downstream to cover the coarse deposit. Such action results in a nucleus or center of coarse sand veneered with finer and better sorted material, as indicated by this sample.

Sample E.-Another bar deposit but considerably older than the last flow; as seen in the photographs the position of $E$ is at the top of a terrace. At the time of deposition this was a part of the main channel though slightly to the left of the strongest current. The coarser material was spread to the left in a manner similar to the conditions by which sample A was formed. The stream did not maintain this channei very long but owing to influences upstream was shifted to the right.

Sample F.-A coarse sample from a wide fanlike deposit below the break in the stream bank. This break simulated a levee break in a large river at flood time. The waters spread rapidly and deposited the major part of the load near the break, the coarser particles being carried to the outer edge of the fan. Study of the photograph (Fig. 40) will show the remnants of this fan after dissection by a younger channel near G.

Sample G.-A bar deposit, the sample taken from near the inside edge, the stream tending to slip off to the right bank. The relations are very much the same as in samples $A, B$ and $D$.

Sample $H$.- An old bar deposit of one of the early channels. The stream at time of deposition had a large volume and was eroding vigorously a large bank that included much very coarse sand and considerable loess. The point of erosion was at a sharp bend in the stream, and the bar was deposited just below in the straight part of the channel.

The variety of analyses is interesting; certain types are readily recognized, and in general there are certain persistent features. The 
bar deposits as shown by samples A, B, D, E and $G$ have several points in common. The maximum occurs in all cases in the $1 / 2-1 / 4 \mathrm{~mm}$. grade and although it ranges from 44 per cent to 51 per cent the average is 50 per cent. The principal subsidiary grade in all five specimens occurs in the $1-1 / 2 \mathrm{~mm}$. range, and in all cases there is a smaller subsidiary grade in the $1 / 4-1 / 3 \mathrm{~mm}$. range. The secondary maximum occurs in the $1 / 16-1 / 32 \mathrm{~mm}$. grade. The exact proportions are indicated best in sample $\mathrm{E}$.

Specimen $C$ is decidedly unlike any of the other materials. Inspection of figure 40 shows that $C$ is in the position of the last channel. The extreme coarseness of the sample and the apparent lack of sorting are probably due, in part, to the general lack of fine materials and the catching in the rough irregular bed of more large grains than usual. Observations made while the stream was running demonstrated clearly that the larger grains were being transported from the upper sources and because of irregularities in the bed became lodged at this point. The large grains which worked loose were carried away and were deposited at the edge of the drainage basin. The main portion of the finer grades was carried by the weaker currents to the left and deposited on the bar position of sample B.

Sample H does not conform to the bar deposits first described, although it came from a position which probably at one time represented a bar in the channel near the source of the stream and just below a bank in the process of erosion. At the time the sample was taken the position of $\mathrm{H}$ was that of a high terrace and the course of the stream had been changed greatly. The high percentage of coarse materials above the $1 / 2 \mathrm{~mm}$. grade probably is the result of a fresh load deposited just around the bend from the cut bank or point of origin of the coarse grains. The presence of nearly 27 per cent in the silt and clay grades is the result of erosion of a loess bank adjacent to the gravel bank against which the stream was cutting.

Sample $F$ is anomalous in the fact that the major grades occur in the $1-1 / 2 \mathrm{~mm}$. grade rather than the $1 / 2-1 / 4 \mathrm{~mm}$. grade as seen in the other specimens and in that the principal subsidiary grade is in the $1 / 2-1 / 4 \mathrm{~mm}$. range, or below the maximum grade instead of above it. The large secondary maximum in the silt grade is in part due to the fact that this sample was not analyzed by subsidation. The deposit of this material 
followed a break in the levee-like bank through which the stream cut. The channel shifted immediately, the stream spreading out and depositing its load abruptly in much the same manner as an alluvial fan.

\section{STREAM TABLE EXPERIMENT NO. III}

In the previous experiment it was observed that large coarse grains of sand tended to move farther downstream during a given period of time than the much smaller grains. At first it was thought that this observation did not fit with the general conception of the size and amounts of materials carried by a stream of given competency. In order to study this action more carefully, the writer constructed a meandering channel of plaster of paris set in a sand mold on the stream table (figure 43). The plaster of paris was allowed to set and dry thoroughly and later given several coats of shellac. A small amount of fine sand became mixed with the plaster of paris when the cast was being poured. The sand added to the roughness of the bed, which had an even gradient or fall of 2 inches in 10 feet. The length of the channel cast was 14 feet. The velocity of the water at 1.5 gallons per minute was 0.9 foot per second. The volume was varied for different parts of the experiment.

A washed river sand which had been screened to remove the very coarse grains was used in all parts of the experiment.

With the solid bed and sides no material could be picked up by the stream, so any sample taken from a channel deposit was a true representative of the material transported from the source, and any sorting that occurred en route was free of outside contamination. An average of six samples taken from the source materials is given in Table III in conjunction with the tabulation of other analyses.

Samples were taken at various points in the channel where the bars formed. Figure 43 shows the bars after a 30 minute run. The points of curves are numbered downstream 1,2 and 3 , and the numbers given to the samples refer to the bars which formed in the straight part of the channel just below the curve points.

Numbers 1,2 and 3 of Table III are the analyses of the materials deposited below the curves after a five minute run at average velocity and volume. This time period was sufficient to form bars large enough to sample. A very small bar formed at the point of curve 3 , but the amount of material was less than two grams; the dozen or so 


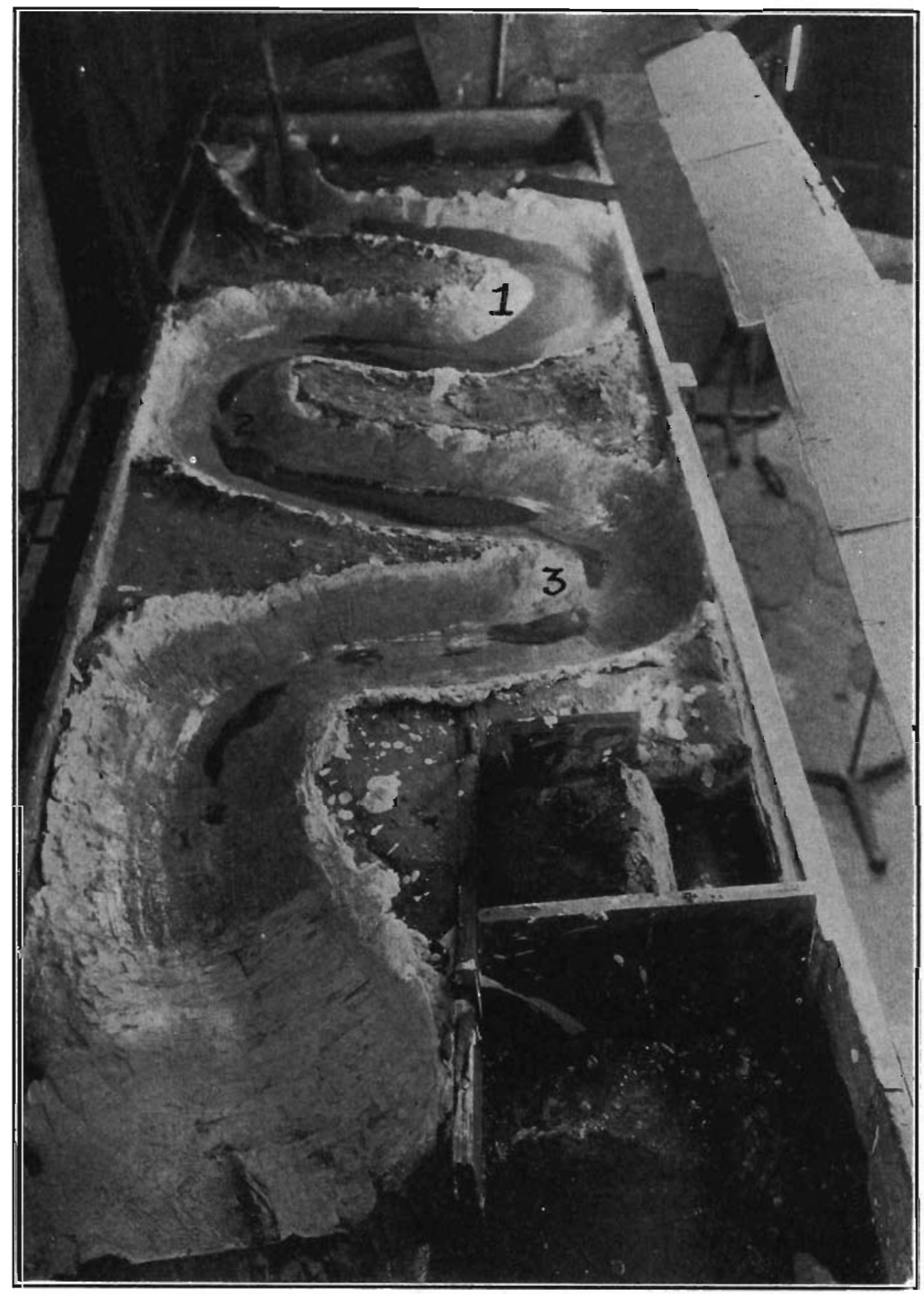

Frg. 43.-View showing the position of bars after a run of 30 minutes in the plaster of paris channel. 
grains which came to rest at curve 3 were almost entirely of the $2: 1$ $\mathrm{mm}$ grade. The three analyses $(1,2$ and 3 ) of the material deposited during this short run show without question that the greatest concentration of the coarse load during any definite time period occurs downstream. The source material fed to the stream was handled quickly by the current, and by direct observation one sees the rapid transportation of the largest particles and the slower but more massive movement of the finer materials. The rate of movement of the large grains is almost that of the flow of the stream, a large grain reaching the end of the channel in 18 seconds after the material was fed at the head. The velocity of the water was 16 seconds for the length of the channel.

TABLE III

\begin{tabular}{|c|c|c|c|c|c|c|c|c|c|c|c|}
\hline in $\mathrm{mm}$. & A & x & 2 & 3 & 4 & 5 & 6 & 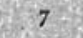 & 8 & 9 & 10 \\
\hline $2-1 \ldots$ & 5.0 & 0.2 & 13.2 & 33.4 & 0.0 & 1.6 & 18.1 & 3.6 & 8.2 & 6.8 & 5.2 \\
\hline $1-1 / 2 \ldots \ldots$ & 35.6 & 23.9 & 58.1 & 55.4 & 8.1 & 22.3 & 40.4 & 43.6 & 51.7 & 37.2 & 38.1 \\
\hline $1 / 4 \ldots .$. & 46.5 & 70.9 & 27.2 & 8.0 & 70.8 & 70.9 & 40.1 & 43.9 & 36.2 & 47.9 & 55.2 \\
\hline.$\ldots$. & 8.1 & 4.5 & 0.3 & 0.3 & 21.1 & 4.5 & 1.0 & 8.3 & 3.1 & 6.8 & 3 \\
\hline$\ldots \ldots$ & 1.2 & 0.4 & 0.4 & 1.1 & $\mathrm{Tr}$ & 0.4 & 0.4 & 0.3 & 0.4 & 0.5 & 0.2 \\
\hline Pan & 3.6 & 0.1 & 0.8 & 1.8 & $\operatorname{Tr}$ & 0.3 & 0.0 & 0.3 & 0.4 & 0.8 & {$[\mathbf{r}$} \\
\hline & & & 0.0 & 0.0 & 100.0 & 100.0 & 100.0 & 100 & 100.0 & 100.0 & 0 \\
\hline
\end{tabular}

A. Average of six samples of source sand.

First run. Average volume and velocity, 5 minutes run to form bars.

1. Point of curve 1.

2. End of long bar below curve 1 .

3. Below point of curve 2

Second run, Low volume, 15 -minute period.

4. Bar at point of curve 1.

5. End of long bar below curve 1

6. Below point of curve 2 .

Third run. High volume, short period 5 minutes.

7. Point of curve 1.

8. End of long bar below curve 1

9. Below point of curve 2 .

10. At end of channel, near drain.

The first particles to come to rest at any of the sites of bar formation were the large $2-1 \mathrm{~mm}$. grains. The bars continued to grow as more of these grains moved down the stream. As time elapsed it was noted that some of the large particles were carried out of the upstrearn bars and passed down to the next bar or continued farther downstream. At the same time the intermediate grades were moving from the source and covering the upper part of the original bar of coarse grains that remained upstream. Thus the final bar included a nucleus of coarse material covered with the finer grades. Comparison of analyses 1 and 3 illustrates clearly the result. Number 1 , close to the source, had lost most of the $2-1 \mathrm{~mm}$. grade and retained a large part of the $1-1 / 2$ mm. grade but had an excess of the $1 / 2-1 / 4 \mathrm{~mm}$. grade. Sarnple number 


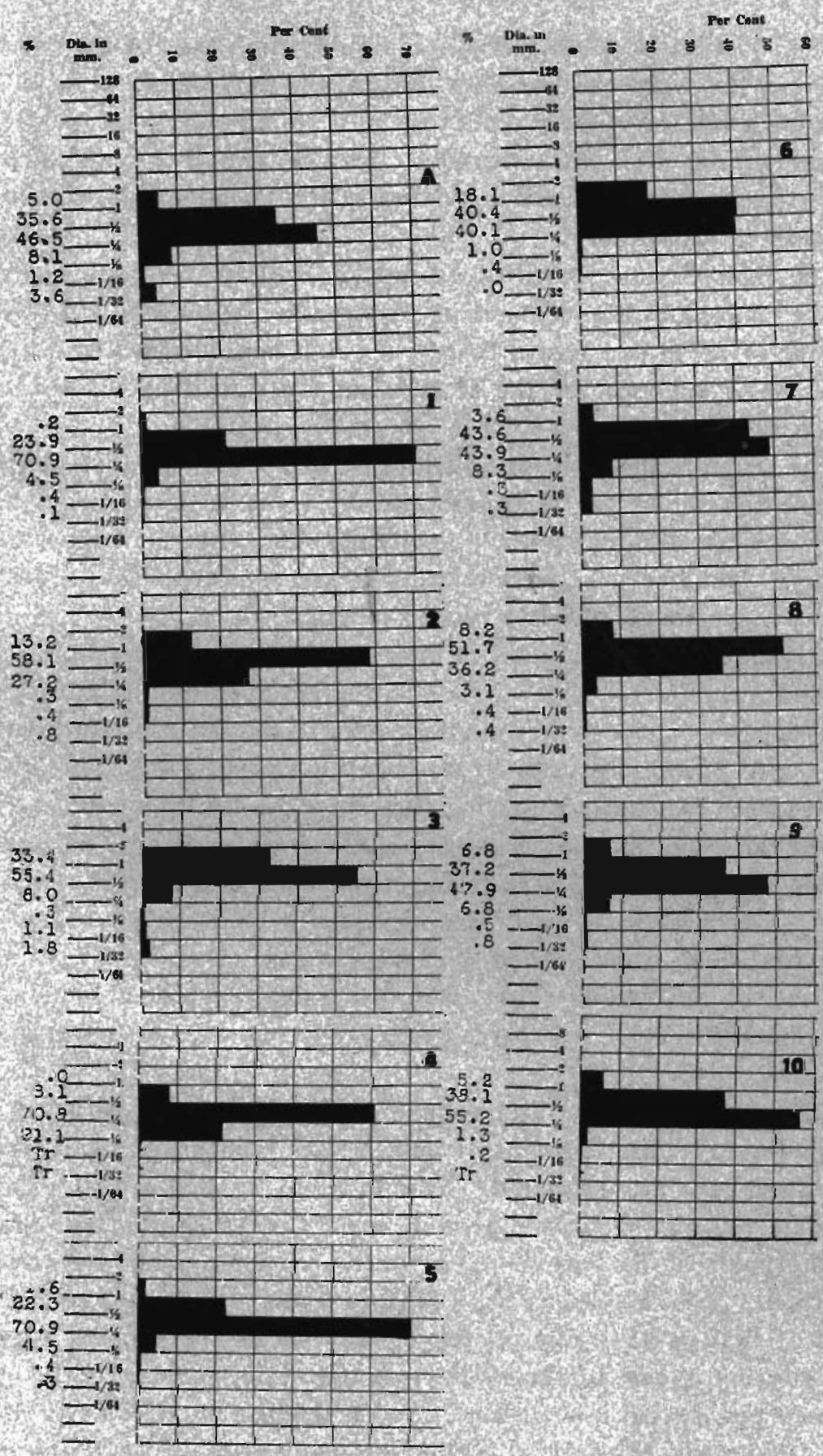

Fr. 44.-Mechanical analyses of deposits in Fxperiment III 
3 , from just below curve 2 , shows a high concentration of the coarsest grains of the source material, one-third of the total sample being of the 2-1 mm. grade, and 55 per cent in the $1-1 / 2 \mathrm{~mm}$. grade, with very small amounts in the four smaller grades. Sample number 2 helps to check these statements as the analysis shows clearly an intermediate position between bars 1 and 3 .

The channel was cleaned of all deposits and for a second run new source material of the same average composition was added. A stream volume of about one-fourth that of the first run described above was used. The analyses for the second run are shown in Table III as numbers 4,5 and 6 .

The action is almost identical with that of the first set-up, and direct observation shows the quick movement of the large particles, their early concentration in bars, and finally the slow advance of the smaller grains. All movements were retarded by the smaller volume of water, so the water was allowed to run 15 minutes.

It is important to note that in both set-ups no movement of fine silt or sand was observed beyond the bars where it appeared in the analysis. In other words, the writer was convinced that the concentration of the coarse grades downstream was not the result of the finer grades having been washed out, making the coarse grades lag materials.

The third run followed a complete cleaning of the channel and adding of new source materials of the same composition as used in the previous runs. The volume of water was increased to double that used in the first run. The results obtained in the third run were nearly identical to those of the former runs. A fourth sample, which also indicates the concentration of the coarse grades downstream, was taken in the last run.

The effect of velocity and volume of the water, or competency, on its power to transport grains of known sizes is indicated clearly when the three runs are compared. The first run, or that with the intermediate velocity, shows the greatest concentration of the large grades at the point of the second curve; or the farthest point downstream analyzed. The doubled velocity did not result in a greater concentration of the coarse grades, as might have been expected, but instead, caused a movement of the source material in almost exactly the same proportions present in the material fed at the source. The low velocity and volume did not cause a complete abandonment of the coarse load 
nor a large increase in the fine grades. Instead, there was an increase in the intermediate grades transported, and the movement of the coarse grades in greater proportions than contained in the parent sand was continued.

In a natural condition it is true that local contributions from tributary streams, bank erosion and slope wash may mask the range of materials which are being carried through from the headwaters or from the parts of the stream which are carrying the heavier loads. The material normally studied is the net result of all of these factors. When it is possible, however, to distinguish mineral or rock constituents and trace the source of these particles, then it may be possible to use the information gained from these experiments.

The "peanut" gravels of the Dakota stage of Montgomery county in southwestern Iowa and east of Louisville, Nebraska, along Platte river, contain vein quartz, quartzite and brown chert pebbles. The writer believes this material was derived from the land areas to the north and northeast in parts of Minnesota, Wisconsin and eastern Iowa, and that the streams at the time of deposition had their mouths relatively close to the places where the deposits are now exposed. The pebbles are all well worn and very few have prominent elements of angularity. The pebble beds do not represent fresh materials contributed as the result of short transportation from a newly uplifted area but are constituted of materials which have been carried through from a long distance and concentrated during transportation. The thicker beds are indicative of major accumulations from the principal or main channels. Where the gravels occur with lenses of finer materials, as at Coburg, Iowa, the competency of the stream probably was increased.

In making interpretations of mechanical analyses or of the textures of sands which have a concentration of coarse materials with the fines lacking or. of small percentage, the statement is frequently made that the fine grades have been carried out and may be found farther from the source. The writer believes this statement may be true in some cases, but he believes also that there are cases where the fines may be found closer to the source, having not yet reached the site of deposition of the coarse sands.

The writer wishes to acknowledge the assistance given him in several 
parts of these experiments by the students of the 1929 class in sedimentation laboratory work. After the above results were secured, several students continued the work and obtained corroborative results.

\section{Appendix A}

\section{Laboratory Methods Used in the Analysis of Dakota Sands}

The study of any stratigraphic sequence has for its purpose, even though it may be used commercially, the increase of knowledge concerning the rocks involved. Such an increase in knowledge will ultimately improve the character of the interpretations made concerning these rocks and, therefore, yield a truer picture of their history. To accomplish this end careful field observations must be made, and notes must be taken of minor details and variations of texture, cross-bedding, ripple marks, concretionary zones, gradations of cementation and any other prominent lithologic features. Also, it is now recognized that other features of the rocks are best understood after a complete analytical laboratory study. The degree of precision and completeness of this study may vary considerably to suit the problem. At the beginning of the study, when the possibilities are unknown or uncertain, the work should be thorough. One factor or set of analyses may yield results in one study while other sets of analyses may be more valuable in other work.

Sedimentary rocks have been given so little careful analytical attention that little is known of the true value of mechanical, mineral and shape analyses, contemporaneous structures, alterations and concentrations of minerals. An effort has been made in the previous chapters to interpret findings of that nature. When more analyses have been made and compared, with some experimental work to check the interpretations, with more observations on present day environments, such conclusions can be made and used with greater surety. For the present, it is well to make laboratory studies and record the observations for future interpretation or comparison with later work. The data should be obtained in a quantitative form to be of comparative value.

In the study of the Dakota rocks, both in the field and in the laboratory, the need for quantitative data has been recognized. To aid others in similar work the methods used by the writer in studying the Dakota rocks and now generally used in the sedimentation laboratory at the University of Iowa, and some of the steps in the procedure, are shown 
in outline form below. The outline is followed by a brief discussion of some of the methods.

A. Sampling (Field)

Outline of Analytical Work

1. Composite specimen $\}$ Vertical and horizontal

3. Notebook sketches and diagrams of textures, structures and relations to bedding

B. Splitting samples for analysis (Field and Lab.)

C. Preparation of samples (Laboratory)

1. Crushing Clay, shale, silt, limestone

2. Cleaning Ferruginous, clayey and dirty sands

3. Freeing of cement.

D. Mechanical analysis

1. Inspection of sample

2. Subsidation

3. Sieving

Screens

Mechanical shaker

Cleaning of screens

4. Filing of separates

E. Mineral separation

1. Selection of grades

2. Electromagnet

3. Heavy liquids

Evaporating dish

Separatory funnel

Centrifuge

F. Mineral determinations

1. Binocular microscope

Sight recognition

Microchemical tests

2. Petrographic microscope

Immersion in index of refraction liquids

Determination of optical properties

Reference to tables based on refraction index, birefringence, light-axis relation, optic sign, pleochroism, etc.

G. Shape analysis

1. Comparative method

2. Quantitative measurements

H. Plotting of results

\section{DISCUSSION OF PROCEDURE}

A. Field sampling. - The method of taking a sample differs somewhat according to the use and character of the specimen. As much of the material used in the study of the Dakota stage is well consolidated, a small hand specimen was taken from the most representative part of the exposure or a series of small chips was taken from various parts of the zone. Study of this type of material can best be made from a thin section.

When the material is of a friable, loosely cemented type, or is bound 
by limonitic iron oxide or calcite, small hand specimens containing two or three hundred grams, taken across the bedding or parallel with the bedding, are satisfactory. When a composite specimen is desired, the face of the exposure is cleaned with a hammer, and then the fresh face is cut down carefully, catching the rock fragments in a small hand scoop, care being taken to cut off the same amount of material for each unit of the vertical face. Usually it is good practice to take a large sample in this manner and then quarter it to the desired amount.

Of equal importance is the care given to the explanation of the position in the rock ledge from which each sample is taken. If a sample is taken from a single foreset zone or from a portion of a ripple zone or a mud crack filling or any such position, a brief sketch should accompany the sample so that accurate interpretations can be made from the mechanical analysis. In the case of composite samples the notes should indicate the nature of the bedding and texture of the zones included in the sample. Wentworth ${ }^{15 \overline{3}}$ gives other details and precautions for taking samples, methods of labelling and other miscellaneous information.

B. Splitting samples for analysis.-It is especially important that the specimen be carefully divided with a good type sample splitter, as any other method of choosing the right amount for analysis does not yield accurate data. ${ }^{156}$

C. Preparation of samples.-The majority of the samples of the Dakota stage which could be handled for a mechanical analysis contained so much of either clay or iron oxide that it was necessary to give them a thorough cleaning before making further studies. In the case of the friable sandstones and siltstones this cleaning was accomplished by washing in distilled water, or water condensed from the steam pipes of the University heating line. The washing process consists of boiling, deflocculating the clay by the use of sodium carbonate, shaking in a cylinder until thoroughly mixed and allowing the coarser grains to settle for a five minute period. The material left in suspension is then siphoned off and caught in a beaker. The sand in the cylinder and clay in the beaker are filtered separately, dried and screened. If the amount of clay and silt is less than 10 per cent it is

\footnotetext{
155 Wentworth, C. K., Methods of Mechanical Analysis of Sediments: Univ. Iowa Studies
in Nat. Hist., Vol. 11, No. 11, N. S. 117, pp. 9.17, 1926.

180 Wentworth, Idem, pp. 18-20.
} 
not separated further but shown in the analysis as the minus $1 / 32 \mathrm{~mm}$. grade.

The ferruginous sands had to be treated with acid before any type of mechanical separation could be used. The common procedure is to use a 15 to 18 per cent hydrochloric acid solution with about 10 per cent of dilute stannous chloride. This is very effective in removing the iron oxide. Some of the ferrous iron goes into solution in the dilute acid and can be washed out or filtered. Usually the balance of the iron oxide remains as a feathery flocculent. When the specimen is free of acid this material can be put in suspension by adding sodium carbonate. The material is then siphoned and the residue remaining in the bottom of the cylinder is filtered, dried and analyzed. A clean white sand results. This method has been used with practically all of the sands of the Dakota that have been analyzed as there are very few which do not contain iron oxide.

The few specimens cemented by calcite were dissolved in a dilute hydrochloric acid, washed free of the acid, filtered, dried and analyzed.

D. Mechanical analysis. - The procedure followed is similar to that described by Wentworth ${ }^{157}$ but with several modifications to fit the particular samples. A mechanical shaker was used and each sample was given a ten minute period of shaking. Considerable care was exercised in cleaning the screens after each analysis, and two sets of six inch calibrated screens were used for this particular work. The clean sands, freed of iron oxide, clay, or other adhering materials, will pass through the sieve with less material sticking in the mesh.

The method of subsidation used by the writer differs somewhat from the method of elutriation described by Wentworth. ${ }^{158}$ Directions for analysis by subsidation are given below.

A. Preparation of specimen

1. Crush carefully to a practical size, without breaking the granular particles. Roll with light metal roll on glass plate.

2. Weigh carefully on triple beam balance to $0.01 \mathrm{gram} ; 10$ to $15 \mathrm{grams}$ of clay, shale, loess, or silt is ample; limestone or other soluble samples demand 40 to 50 grams to provide a sufficient residue for analysis.

3. If materials are calcareous and the percentage of soluble material is desired, treat a small weighed part of the specimen with $\mathrm{HCl}$; boil slowly for 3 to 5 minutes, or until solution ceases. Filter after moderate cooling.

4. Mix specimen (not acid treated) with distilled water and heat slowly; if the clay does not stay in suspension on cooling, add one-half to one gram sodium carbonate to aid deflocculation, then heat slowly until all but coarse grades are in suspension. Allow to cool to room temperature.

157 Wentworth, Idem, pp. 20-35, 39.43.

158 Idem, p. 39. 
B. Separation by settling

1. Pour prepared material, into graduated cylinder and fill latter with distilled water to height of $15 \% / 2$ inches.

2. By closing open end of cylinder with palm of hand, shake the liquid well, seeing that the sediment is well toward top. Set on table and allow to settle without agitation for 5 mimutes. Time with a stop watch.

3. Insert siphon tube carefully and start siphon action at expiration of the 5-minute period. Collect the liquid thus siphoned in a $1,000 \mathrm{cc}$. beaker with a depth of $5 x / 2$ inches to $53 / 4$ inches. (See 7.)

4. After a gentle agitation of liquid obtained in (3) allow it to settle 5 minutes, again using stop watch for tinning.

5. At end of five-minute period noted in (4) siphon carefully with a fiveinch glass siphon tube into another $1,000 \mathrm{cc}$. beaker. This liquid just siphoned is allowed to settle 15 minutes.

6. Siphon into sink the liquid obtained in (5) at end of 15 minutes.

7. After completing (3) the residue in the cylinder should be washed again with distilled water by filling to $151 / 2$-inch level, shaking and allowing to settle.

8. The operation in (7) starts a new series usually called the "second period" which is simply a repetition of the steps outlined in $3,4,5$ and 6 .

9. Repeat to third period of settling, and if liquid in the $15 x / 2$-inch column does not clear immediately after shaking in third period continue to fourth or more periods as deemed necessary.

10. Weigh to nearest 0.01 and label completely, filter papers to receive the various fractions at end of settling.

11. Wash final settling products into respective filter papers.

12. After complete filtering, place filter paper with residue in oven to dry. After 2 or 3 hours drying at 80 to 90 degrees C. remove from oven and allow to cool on protected shelf. Then weigh to $0.01 \mathrm{gram}$ on laboratory balances. Subtract weight of filter paper from gross weight to get net weight of each grade.

\section{SUPPLEMENTARY NOTES:}

A. Cautions (Referring to numbers above)

(A1) In the case of a fine-grained sediment much care must be exercised to prevent fracturing grains. If possible break with fingers or allow to stand in water over night to aid separation. In some cases, e. g., a ferruginous sandstone, the specimen. must be boiled in acid to perfect granular disintegration.

(A2) Usually a smaller amount of fine materials will suffice. However, be careful the coarse grade does not fill the bottom of the cylinder to the level of the siphon tube.

(A3) If it is necessary to use the acid-treated sample for settling analysis be sure to wash out all the acid during the first filtering process.

(A4) Use a small quantity of sodium carbonate. An excess may cause a reversal of action. If the liquid is too warm convection currents may prevent settling of particles desired.

(B3) Be careful of time periods. Do not undertime. If the period is allowed to run overtime, the error may be corrected by washing and siphoning another period. An error of undertiming cannot be readily corrected. Use care that end of siphon does not disturb the sediment in the bottom of the cylinder.

B. Results

(a) The sediment which remains in the bottom of the cylinder after the numerous periods of washing has a settling rate of 15 inches in 5 minutes or faster. This comprises the materials $12 \mathrm{~mm}$. and larger in diameter.

(b) The material which settles to the bottom of the first beaker (See B3 above) has a settling rate of 5 inches in 5 minutes or just $1 / 3$ that in the tall cylinder. This beaker contains the $1 / 6+\mathrm{mm}$. grade. 
(c) The second beaker containing the siphoned product of (b) has a water column of 5 inches, hence a settling period of 15 minutes is necessary. The sediment which is retained in bottom of beaker is the $1 / 128 \mathrm{~mm}$, grade.

(d) The liquid siphoned to the sink in the last process represents everything smaller than the $1 / 128 \mathrm{~mm}$. grade. The quantity of this grade is determined by difference.

(e) Frequently the analysis is carried only to the second grade; that is, the $1 / 128 \mathrm{~mm}$. grade is not determined, but lumped with all other fine grades. This depends on the ease with which separation of particles and deflocculation is attained and the importance or abundance of the finer grades.

The settling ratio of 3 is nearly constant for the range between $1 / 16$ and $1 / 128 \mathrm{~mm}$. Below or above these sizes the ratio may vary. According to Stokes' law. small particles fall in a column of water with velocities proportional to the square of their diameter. Experiments with various distances of settling and microscope measurements of the different separates has shown that the particles which settle 5 inches in 5 minutes are almost exactly one-half the diameter of those which settle 15 inches in 5 minutes. The same ratios appear to hold for a third smaller grade. It is true that careful work is essential to hold the grain sizes within the limits of the grades desired.

\section{E. Mineral separation.-1. Electromagnetic separation}

The sands of the Dakota stage contain very little magnetite or other moderately magnetic minerals. Attempts have been made to separate the minerals contained in these sands by the use of a strong electromagnet. A magnetic separator based on the principle of the Dings wet separator was designed by the writer and made at the University of Iowa and serves satisfactorily for the average separation. The sand is placed in a long tube filled with water. This tube is set between the pole pieces of the magnet and moved back and forth along the axis of the tube to agitate the water and to keep the grains free. With varying amounts of electric current different minerals are held against the glass of the tube. The writer has not yet been able to calibrate the instrument other than to effect separations of magnetite, ilmenite and glauconite from the other minerals in the sand.

The electromagnetic separator may be used in conjunction with a calibrated tube, such as a quantitative centrifuge tube, to determine the volume of magnetic substances in a loose sand or crushed sample. Johnson ${ }^{159}$ applied this method to determine the amount of casing scale in well cuttings, which in turn aided in correlation of water zones.

2. Heavy liquid separation

169 Johnson, H. L. Correlation of Five Oil Wells in Texas; Uniy. of Texas Bull. 3001, pp. 139-147, 1930; and unpublished thesis, Univ. of lowa, p. 6, 1930. 
Many writers have described the use of the ordinary separatory funnel in making mineral separations in liquids of high density. This method is satisfactory for grains ranging in sizes between $1 \mathrm{~mm}$. and $1 / 4 \mathrm{~mm}$. For larger grains and in some cases with grains as small as $1 / 8 \mathrm{~mm}$. an ordinary two inch porcelain evaporating dish can be used satisfactorily. The dry grains are placed in the dish, which is then half filled with bromoform or any other heavy liquid to be used. Usually it is sufficient that the dish be half full of the liquid, but a larger amount of the liquid makes it possible to pour off the floating grains with greater ease. With the liquid in the dish a small amount of agitation such as a whirling motion of the dish mixes the grains sufficiently and will usually free any adhering grains. When the operator is satisfied with the separation the light or floating minerals are poured into a filter paper and the bromoform is caught in a container below. This bromoform can be used many times as it is not necessary to dilute it with a washing liquid. The heavy minerals which sink to the bottom of the evaporating dish and are now free of all but a few drops of bromoform are washed to a clean filter paper. Distilled water or benzol is usually used for this washing process and is caught below the filter paper in a bottle and saved for distillation.

To separate grains of dimensions smaller than $1 / 8 \mathrm{~mm}$. the evaporating dish or separatory funnel does not yield the best results, as there is too great a tendency for the grains to stick together. The small amount of moisture on the grains or the water in the bromoform prevents a complete disaggregation of the small grains. In order to prevent such an occurrence the grains should be dried thoroughly and the bromoform carefully distilled to drive off all moisture. A clean separation of heavy and light minerals can be obtained by using a centrifuge. In the laboratory at the University of Iowa a Bausch and Lomb electric centrifuge with guard has been used successfully. The centrifuge can be used for the separation of coarser grains, but as it takes more time than the evaporating dish method, and as the grains do not adhere as firmly in the larger grades, the method is seldom used. It is possible, however, to determine the quantity of heavy minerals directly by using a calibrated centrifuge tube.

Brown ${ }^{160}$ has described the use of the centrifuge in making separations of the heavy minerals of soils. Brown found that by using a

180 Brown, I. C., Jour. Paleo., Vol. 3, No. 4, pp. 412-414, Dec., 1929. 
snall glass capsule fused to the end of an ordinary centrifuge tube he could make a very clean separation of light and heavy minerals in bromoform and at the same time recover the grains without contamination and the loss of bromoform and could thus make quantitative determination of the heavy minerals present in the soil. This method was worked out in the sedimentation laboratory at the University of Iowa under the direction of the writer. It has been necessary in only two or three cases to use this method in separating the heavy minerals of the Dakota samples.

F. Mineral determinations. - The usual methods for determining minerals have been followed in the present study. It is only after considerable practice and accumulated knowledge that it is possible to make accurate determination of minerals in a sedimentary rock by the use of the binocular microscope alone. It is impossible to differentiate the various species of feldspars, amphiboles and pyroxenes, or to recognize grains of quartzite and many other clear or glassy types. In general the writer prefers to use a petrographic microscope to study the minerals of a rock as individual grains or in thin section.

A common practice is to take the separate of minerals obtained from a heavy liquid separation and study them with a binocular microscope. Minerals which occur in large proportions in the separate are segregated and several grains of each are placed in a small shell vial or gelatine capsule. After all of the prominent species have been sampled in this manner, the work is transferred to the petrographic microscope. Several grains are selected from one of the vials and subjected to a critical study. The grains are crushed, if necessary, and immersed in an index of refraction liquid of known value. This is continued until the limits of the indices are known; experience reduces these trials to a minimum. At the same time that the indices are being determined it is possible to note many of the optical properties of the mineral. With these facts it is possible to trace the mineral to its proper classification. The index of refraction liquids used in the University of Iowa laboratory are described by Emmons. ${ }^{162}$ This method of mineral determination yields the best and most reliable results.

G. Shape analysis.-It is generally supposed that the shapes and surface features of the constituent grains of a sandstone aid in the

161 Emmons, R. C., Amer. Min., Vol. 13, pp. 514-515, 1928. 
recognition of the environment of deposition. More stress has been placed on this criterion than the writer feels is justified. It seems possible that grains of similar shape or surface characteristics are deposited by different agents in environments of a wide range. However, in order to make the study of the sediments complete the writer feels that it is desirable to make the shape determinations.

The majority of the workers have established schemes of their own and describe the grains as "rounded," "well-rounded," "subround," "subangular," "angular," and various modifications of these terms. They have no accurate quantitative basis for classifying the shapes into these groups, and it is very difficult to evaluate or to compare the work of different investigators. Some workers select grains of different shapes, mount them, and use them throughout their particular problem to compare with the grains of the various samples of their studies. This is satisfactory from their point of view, and in most cases the determinations made by the individuals are true to their standards. A good illustration of this method may be had in the work of Trowbridge and Mortimore. ${ }^{162}$ Undoubtedly, the grains classified as "round" by these authors would compare closely with photographs of round grains. However, another worker who has a different conception of round grains might call such grains "subround." The application is of more importance when one is dealing with grains which have some fresh surfaces and edges but yet have undergone sufficient abrasion to wear the most prominent surfaces and corners. Few attempts have been made to measure the amount of abrasion of sand grains and then express the results in a numerical value so that any stated value would fall in its proper place. Arbitrary divisions placed in these numerical values would give the basis for the use of such terms as "round," "subangular," etc.

In 1927 Cox $^{163}$ discussed this problem and decided that it is possible to make a determination from sand grains which will yield quantitative measurements. $\mathrm{He}$ bases his determinations upon the ratio of the area of a cross section of a grain to the area of a circle which has the same circumference as the perimeter of the measured grain. It is obvious that a grain with a large number of sides and with nearly equal radii, when seen in cross section, will yield a ratio approximating that of a circle with the same perimeter. Even a square,

162 Trowbridge and Mortimore, Econ. Geol. Val. 20. pp. 409-423, 1925

108 Cox, E. P.. Jour. Paleo., Vol. 1, pp. 179-183, 1927. 
or a cube when considered as a three dimensional body, will yield a ratio of over 78 per cent, while an isosceles triangle will yield a ratio of 54 per cent. The writer believes that such ratios are misleading, as the cube or pyramid may be fresh and have suffered very little wear. He believes that ary standard of the measurements of shapes of grains should be based upon the relative amount of wear on the grain. This means, of course, that some postulate must be made of the original shape of the grain prior to its abrasion.

The writer devised a method by which the shape of grains could be measured and expressed in quantitative terms. ${ }^{164}$ The basis or fundamental on which such determinations and interpretations should be based is the amount of wear or abrasion that has affected any given grain. This can be called the factor of wear.

Wentworth ${ }^{105}$ bases his considerations and measurements of pebbles and cobbles on a similar principle and expresses it as the roundness or (and) flatness ratio. A sand grain has fewer developed ${ }^{166}$ facets than pebbles. $\operatorname{Cox}^{167}$ avoids the ratio of wear as a basis of measurement and uses the ratio of areas of the grain at the time of measurement as compared with a theoretical area the grain would have if its cross section were a circle of the same perimeter. This might be called dealing in futures as it attempts to evaluate the abrasion to be accomplished if a perfect sphere results rather than what has already been done.

The writer is convinced by his observations on the shapes of pebbles and sand grains, gained from field and laboratory studies, that the original shape of the rock or grain when it is first subjected to abrasion is a primary control on the ultimate shape. In addition to this the composition and structure of the fragment sometimes influences the place and rate of abrasion. The nature of the abrading agent is a factor of unknown value and may be a greater influence in the ultimate shape of a pebble in one set of conditions, while in another environment the same agent may have little effect.

\footnotetext{
16s Tester, A. C., Measurement of Shapes of Rock Particles: Jour. Sed. Petrology, Vol. 1, No. 1, May, 1931, pp. 3-11.

165 Wentworth, Jour. Geol., Voi. 27, pp. 507.521 , 1919; and U. S. G. S. Bull, 730c, p. 93, 1922, 169 Wentworth 7 ult $730 \mathrm{c}, 93$.

267 Cox, op. cit. p. 181.
} 


\section{Appendix B \\ Bibliography}

The bibliography is divided into two parts; part one includes the publications which make a specific reference to the type area of the Dakota stage or which aided in the earliest studies of the region; part two contains the general articles on the Dakota in other localities, articles pertaining to methods, procedure, paleontology, and general principles.

In this bibliography an attempt has been made to bring together a complete list of articles which make a contribution to the knowledge of the rocks of the Dakota stage in northeastern Nebraska and adjacent Iowa, the type area. Many articles which make only a passing reference to the Dakota section have been excluded. Articles which use the Dakota sections of previous writers or have used conclusions found elsewhere have for the main been omitted.

Practically all of the articles included in the first part of the bibliography have been reviewed by the writer, even though no reference is made to these articles in the historical summary. The publications cited in part two contain material used in the present writing or have been consulted for comparative purposes or are generally familiar to the writer.

The chronological arrangement of part one is used for ready reference and as a general guide to the development of the studies and knowledge of the Dakota stage. Part two is arranged alphabetically by authors. The numbering of the references is corisecutive through both parts.

\section{PART I}

ARTICLES RELATING TO TYPE AREA OF DAKOTA STAGE 1804

1. Thwaites, Reuben Gold, editor Original Journals of Lewis \& Clark, 18041806, in 7 vols. Dodd, Mead \& Co., New York, 1904.

(Note: With the exception of reference No. 2 the bibliography does not contain references to a large number of publications made by members of the Lewis \& Clark party or by other persons who claimed access to the original records. Some of the publications are known to be spurious, while others are based on partial data or on badly edited and abridged notes. The edition by Thwaites contains all the original diaries, unpurged, including those of Gass, Floyd and other subordinates.)

2. Allen, Paul, and Biddle, N. (editors), History of the expedition under the, command of Captains Lewis and Clark to the sources of the Missouri; 
thence across the Rocky Mountains and down the river Columbia to the Pacific Ocean performed during the years 1804-1806. Two vols., 470 pp. and 522 pp., maps, etc. Philadelphia, 1814. See pp. 49-51.

3. Maclure, William, Observations on the Geology of the United States, explanatory of a geological map: Am. Phil. Soc. Trans., Vol. 6, pp. 411-428, map, 1809.

4. Bradbury, John, Travels in Interior of America in 1809-1811. London, 1817 (second edition, 1819). Reprinted as Vol. 5, Early American Travels, 17481846, edited by Reuben Gold Thwaites, published by Arthur H. Clark Co., Cleveland, 1905.

5. Maclure, William. Observations on the Geology of the United States of America. 127 pp., map. Philadelphia, 1817.

6. Nuttall, Thomas, Geological Structure of the Valley of the Mississippi: Phila. Acad. Nat. Sci. Jour., Vol. 2, pp. 14-52, 1821.

7. James, E., Account of Expedition from Pittsburg to the Rocky Mountains performed in 1819-1820, under the command of S. H. Long. Description of fossils by Thomas Say, Vol. 1, p. 106, and Vol. 2, pp. 410-411, Philadelphia, 1823.

8. Morton, S. G., Philadelphia Acad. Nat. Sci. Jour., 1828, Vol. 6, pp. 59-71, 1829. Geological observations on the secondary, tertiary, and alluvial formations of the Atlantic coast of the United States. Arranged from the notes of Lardner Vanuxem.

9. Vanuxem, Lardner, Remarks on the Character and Classification of Certain American Rock Formations: Am. Jour. Sci., Vol. 16, pp. 254-256, 1829.

10. Morton, S. G., Synopsis of the Organic Remains of the Ferruginous Sands Formation of the United States with Geological Remarks: Amer. Jour. Sci., Vol. 17, pp. 274-295, 1830.

11. Morton, S. G., same title as above: Amer. Jour. Sci., Ser. 1, Vol. 18, pp. 243-250, ills., 1830 .

1833

12. Morton, S. G., same title as above: Amer. Jour. Sci., Ser. 1, Vol. 23, pp. 288-294, ills., 1833.

13. Morton, S. G., same title as above: Amer. Jour. Sci., Ser. 1, Vol. 24, pp. 128-132, 1833.

14. Nicollet, J. N., On the Geology of the Region on the Upper Mississippi and the Cretaceous Formation of the Upper Missouri: Amer. Jour. Sci, 
Ser. 1, Vol. 41, pp. 180-182, 1841. See also Assoc. Amer. Geog. Rep., pp. $32-34,1843$.

15. Nicollet, I. N., On the Cretaceous Formation of the Missouri River (with discussion): Amer. Jour. Sci, Ser. 1, Vol. 45, pp. 153-159, abstr., 1843.

16. Owen, D. D., Geological Survey of Wisconsin, Iowa and Minnesota, and Incidentally a Portion of Nebraska Territory; made under direction of U. S. Treasury Dept: Phila., 1852 , p. 195.

17. Marcou, J., Resume Explicatif d'une Carte Geologique des Etats-Unis et des Provinces Anglaises de 1 Amerique du Nord, etc.: Bull. de la Soc. Geol. de France, 2 Ser, Vol. 12, pp. 813-936, map, 1855

18. Hall, James, and Meek, F. B., Descriptions of New Species of Fossils from the Cretaceous Formations of Nebraska: Am. Acad. Arts, Mem., N. S., Vol. 5 , pp. $379-411,1856$.

19. Hayden, F. V., Geological Notes, etc., on Nebraska, A part of G. K. Warren's Explorations in the Dakota Country in the Year 1855: U. S. 34th Cong., 1 st Sess., Sen. Ex. Doc. 76, pp. 66-79, 1856.

20. Meek, F. B, and Hayden, F. V., Descriptions of New Fossil Species of Mollusca Collected by Dr. F. V. Hayden in Nebraska Territory: together with a complete catalogue of all remains of invertebrata hitherto described and identified from the Cretaceous and Tertiary formations of that region: Phila. Acad. Nat. Sci. Proc., Vol. 8, 1856, pp. 265-286, 1857.

21. Meek, F. B., and Hayden, F. V., Deseriptions of New Species of Gastropods from the Cretaceous Formations of Nebraska Territory: Phila. Acad. Nat. Sci. Proc., Vol. 8, 1856, pp, 63-69, 1857.

22. Hall, James, Observations on the Cretaceous Stratal of the United States: Am. Jour. Sci., Ser. 2, Vol. 24, pp. 72-86, 1857. See also U. S. 34th Cong. 1st Sess., S. Ex. Doc. 108 and H. Doc. 135, Vol. 1, Part 2, pp. 126-138.

23. Marcou, Jules, American Geology; letter on some points of the geology of Texas, New Mexico, Kansas and Nebraska, addressed to Messrs. F, B. Meek and F. V. Hayden, 16 pp. Zurich, 1858.

24. Hayden, F. V., Geological Structure of the Country Bordering on the Missouri River, from the Mouth of the Platte River to Fort Benton in Lat. $47^{\circ} 30^{\prime}$ N., Long. $110^{\circ} 30^{\prime} \mathrm{W}$ : Phila. Acad. Nat. Sci. Proc. 1857, Vol. 9, pp. 109-116, map, 1858.

25. Meek and Hayden, Description of New Species and Genera of Fossils Collected by Dr. F. V. Hayden in Nebraska Territory, with some remarks on the Tertiary and Cretaceous formations of the northwest: Phila. Acad. Nat. Sci. Proc. Vol. 9, 1857, pp. 117-133, 1858.

27. Meek, F. B, and Hayden, F. V. Remarks on the Lower Cretaceous Beds of Kansas and Nebraska, Together with Descriptions of Some New Spe- 
cies of Carboniferous Fossils from the Valley of Karisas River: Phila. Acad. of Nat. Sci. Proc., Vol. 10, 1858, pp. 256-260, 1859. See also Am. Jour. Sci, Ser. 2, Vol. 27, pp. 219-227, ills., 1859.

28. Heer, Oswald, Descriptions of Fossil Plants from No. 1 of the Nebraska Section (of Meek and Hayden): Phila. Acad. Nat. Sci. Proc., Vol. 10, 1858, pp. $265-266,1859$.

29. Meek, F. B., and Hayden, F, V., On the So-called Triassic Rocks of Kansas and Nebraska; Am. Jour. Sci., Ser. 2, Vol. 27, pp. 31-35, 1859.

30. Agassiz, Louis, On Marcou's Geology of North America: Am Jour. Sci., Ser. 2, Vol. 27, pp. 134-137, 1859.

31. Newberry, J. S., Explorations in New Mexico: Am. Jour. Sci, Ser. 2, Vol. 28, pp. $298-299,1859$.

32. Newberry, J. S., Notes on the Ancient Vegetation of North America: Amer. Jour. Sci, Ser. 2, Vol. 29, pp. 208-218, 1860. Also A. J. S., Ser. 2, Vol. 30 , pp. $273-275,1860$.

1861

33. Heer, Oswald, On the Age of the Nebraska Leaves: Am. Jour. Sci, Ser. 2, Vol. 31, pp. $435-440,1861$

1862

34. Meek, F. B, and Hayden, F. V., Descriptions of New Lower Silurian (Primordial), Jurassic, Cretaceous, and Tertiary Fossils, Collected in $\mathrm{Ne}$ braska, by the Exploring Expedition under the Command of Capt. Wm. F. Reynolds, U. S. Top. Engineers, with some remarks on the rocks from which they were obtained: Phila. Acad. Nat. Sci. Proc., Vol. 13, 1861, pp. 415-447, 1862. Also, abst., Am. Jour. Sci., Ser. 2, Vol. 34, p. 137, 1862.

1803

35. Hayden, F. V. On the Geology and Natural History of the Uipper Missouri: An. Philos. Soc. Trans., Vol. 12, n. s., 1862, pp. 1-218, 1863.

1804

36. Marcou, Jules, Une Reconaissance Geologique au Nebraska: Bull. Soc. Geol de France, 2 Ser, Vol, 21, pp. 132-146, 1864.

1865

37. Meek, F, B., Remarks on the Carboniferous Rocks of Eastern Kansas and Nebraska and Their Relations to Those of the Adjacent States, and Other Localities Farther Eastward; in connection with a review of a paper recently published by J. Marcou (in the Bulletin of the Geological Society of France): Am. Jour. Sci, Ser. 2. Vol. 39, pp. 157-173, 1865.

1860

38. Capellini, J. et Heer, O., Les Phyllites Cretacees du Nebraska: Mem. Soc. Helvetique des Sci. Nat., t. XXII, Pp. 1-24, 1866. 
39. Hayden, F. V., Remarks on the Cretaceous Rocks of the West Known as No. 1, or the Dakota Group: Am. Jour. Sci., Ser. 2, Vol. 43, pp. 171-179, 1867.

40. White, Charles A., On the Geology of Southwestern Iowa: Am. Jour. Sci., Ser. 2, Vol. 44, p. 23, 1867.

41. Marcou, Jules, Le Terrain Cretace des Environs de Sioux City de la Mission des Omatia et de Tekama, sur les Bords du Missouri: Bull. Geol. Soc. de France, 2 Ser., Vol. 24, pp. 56-71, map, 1867.

42. Lesquereux, Leo, On Some Cretaceous Fossil Plants from Nebraska: Amer. Jour. Sci., Ser. 2, Vol. 46, pp. 91-105, 1868.

43. White, Charles A., Report on the Geological Survey of the State of Iowa: Vol. 1, pp. 285-295 (see also pp. 98 and 290), 1870.

44. White, Charles A., Report on the Geological Survey of the State of Iowa: Vol. 2, pp. 186-200, 1870 .

45. Meek, F. B., Lists of Fossils with Descriptions of Some New Types: Geol. Surv. of Wyoming and contiguous Territory, Hayden's Fifth Ann. Rept., pp. $297-313,1872$.

1873

46. White, Charles A., On the Eastern Limit of Cretaceous Deposits in Iowa: Amer. Assoc. Adv. Sci. Proc., Vol. 21, pp. 187-192, 1873; also Abstr. A. J. S., Ser. 3, Vol. 5, pp. 66-69, 1873.

47. Hayden, F. V., Geology of Nebraska North of the Platte River: 1st Ann. Rept. of the U. S. Geol. Survey of the Territories, 1867, p. 629, 1873.

48. Meek, F. B., A Report on the Invertebrate Cretaceous and Tertiary Fossils of the Upper Missouri Country: U. S. Geol. Surv. Terr. (Hayden Surv.) Rept., 9, 629 pp. (with plates of Dakota fossils), 1876.

49. Cope, E. D., Descriptions of New Extinct Vertebrata from the Upper Tertiary and Dakota Formations: Bull. U. S. Geol. and Geog. Surv. Terr., Vol. 4, pp. 379-396, 1878.

50. Lesquereux, Leo, and Newberry, J. S., Illustrations of Cretaceous and Tertiary Plants: U. S. Geol. Surv. Terr., plates and explanations, 1878.

51. Lesquereux, L., The Cretaceous and Tertiary Flora: U. S. Geol. Surv. of Terr., Vol. 8, 1883.

52. White, Charles A., The North American Mesozoic: Pres. Address, Section E, A. A. A. S., from Am. Assoc. Adv. Sci. Proc., Vol. 38, 1889. 
53. Hicks, Lewis E., Report on the Stratigraphy and Hydrology of Nebraska: U. S. 51st Cong., 1 st Sess., Sen. Ex. Doc. 222, pp. 71-86, 1890.

1891

54. White, C. A., Correlation Papers, Cretaceous: U. S. G. S. Bull. 82, pp. 140$164,1891$.

55. Todd, J. E., Notes on the Geology of Northwestern Iowa: Iowa Acad. Sci. Proc. for 1890-1891, Vol. I, Part ii, pp. 13-14, 1892.

56. Lesquereux, Leo, The Flora of the Dakota Group, edited by F. H. Knowlton: U. S. G. S. Mon. 17, 400 pp., ills., 1892.

1893

57. Calvin, S., Relation of Cretaceous Deposits of Iowa to Subdivisions of Cretaceous Proposed by Meek and Hayden: Iowa Acad. Sci. Proc., Vol. I, Part iii, pp. 7-12, 1893. Same paper in Amer. Geol., Vol. 11, pp. 300$307,1893$.

58. Keyes, Charles Rollin, Cretaceous Formations of Iowa: Iowa Acad. Sci. Proc., Vol. I, Part iv, pp. 25-26, 1894. See also Iowa Geol. Surv., Vol. I, pp. 123-138, 1893.

59. Calvin, S., Cretaceous Deposits of Woodbury and Plymouth Counties: Iowa Geol. Survey, Vol. I, pp. 147-161, 1893.

1894

60. White, Charles A., Notes on the Invertebrate Fauna of the Dakota Formation, with Descriptions of New Molluscan Forms: U. S. Natl. Museum Proc., Vol. 17, pp. 131-138, ills., 1894.

61. Todd, J. E., A Preliminary Report on the Geology of South Dakota: S. D. Geol. Surv., Bull. 1, 172 pp., map, 1895. (See pages 82-84.)

62. Bain, H. Foster, Cretaceous Deposits of Sioux Valley: Iowa Geol. Survey, Vol. III, pp. 99-114, 1895.

1896

63. Bartsch, Paul, Notes on the Cretaceous Flora of Western Iowa: Bull. Lab. of Nat. Hist. S. U. I., Vol. 3, No. 4, pp. 178-180, 1896.

64. Bain, H. Foster, Geology of Woodbury County, Iowa: Iowa Geol. Survey, Vol. V, pp. 241-299, 1896. Important for references and descriptions of sections.

1898

65. Ward, L. F., The Cretaceous Formations of the Black Hills as Indicated by the Fossil Plants: U. S. G. S. Ann. Rept., 1897-1898, Part II, p. 703.

1900

66. Gould, Charles N., Some Phases of the Dakota Cretaceous in Nebraska: Am. Jour. Sci., Ser. 4, Vol. 9, pp. 429-433, 1900. 
67. Gould, Charles N., The Dakota Cretaceous of Kansas and Nebraska: Kans. Acad. Sci. Trans, Vol. 17, pp. 122-178, 1901.

68. Burchard, E. F., Geology of Dakota County, Nebraska, with Special Reference to the Lignite Deposits: Acad. Sci, and Lett. Proc., Sioux City, Vol 1, pp. 135-184, 1903-4.

69. Darton, N. H., Preliminary Report on the Geology and Underground Water Resources of the Central Great Plains: U. S. Geol. Surv. Prof. Paper 32, 1905.

70. Condra, George E. Geology and Water Resources of a Portion of the Missouri River Valley in Northeastern Nebraska; U. S. G. S. W. S. Paper 215, 57 PR. 1908.

71. Todd, J. E., Description of the Elk Point Quadrangle, S. Dak-Ia.-Nebr.: U. S. G. S. Geol. Atias, Folio 156, 1908 .

1911

72. Todd, I. E., Is the Dakota Lower or Upper Cretaceous? Trans. Kans. Acad. Sci, Vols. 23 and 24, pp. $65-69,1911$.

73. Twenhofel, W. H. The Comanchean and Dakota Strata of Kansas: Am. Jour. Sci, Ser. 4, Vol. 49, pp. 281-297, 1920.

74. Berry, E. W. The Age of the Dakota Flora: Am. Jour. Sci, Ser. 4, Vol. 50, pp. $387-390,1920$.

1922

75. Stanton, T. W., Some Problems Connected with the Dakota Sandstone: Bull. G. S. A., Vol. 33, pp. 255-272, 1922.

76. Twenhofel, W. H., Geology and Invertebrate Paleontology of the Comanchean and "Dakota" Formations of Kansas: State Geol. Surv. of Kans., Bull. 9, 135 pp., ills., 1924.

\section{PART II}

\section{GENERAL REFERENCES}

77. Bain, H. Foster, Geology of Guthrie County, Iowa: Iowa Geol. Survey, Vol. VII, pp. $413-487,1897$.

78. Bain, H. Foster, Geology of Plymouth County, Iowa: Iowa Geol. Survey, Vol. VIII, pp. 315-366, 1898.

79. Berg, K., Natur and Bildungsweise der Marinen Eisensilikate, Berlin, 1926.

80. Berry, E. W. The Flora of the Cheyenne Sandstone of Kansas: U. S. Geol. Surv. Prof. Paper 129, pp. 199-231, 1922. 
81. Berry, E. W., The Flora of the Woodbine Sand at Arthurs Bluffs, Texas: U. S. Geol. Surv, Prof. Paper 129, pp. 153-181, 1922.

82. Brown, I. C., Separation of Heavy Minerals of Soils: Jour. Paleo, Vol. 3 , pp. $412-414,1929$.

83. Calvin, S., The Niobrara Chalk: Pres. Address, Sec. E., A. A. A. S., 1894, Proc. A. A. A. S, Vol. 43, 1894.

84. Cayeux, L., Introduction a l'Etude Petrographique des Roches Sedimentaires, Paris, 1916.

85. Coues, History of the Lewis and Clark Expedition, Vol. 1, pp. 72-86, 1893.

86. Cox, E. P, A Method of Assigning Numerical and Percentage Values to the Degree of Roundness of Sand Grains: Jour. Paleo., Vol. 1, pp. 179-183, 1927.

87. Cuvier and Brongniart, Jour. des Mines, t. 23, pp. 421-440, 1808. (See p. 436.)

88. Darton, N. H. Geology and Underground Waters of South Dakota: U. S. G. S. Water Supply Paper 227, pp. 41-60, etc., 1909.

89. Emmons, R. C., The Double Disperision Method of Mineral Determination: Amer. Min., Vol. 13, pJ. 505-515, 1928.

90. Geikie, Sir Archibald, The Founders of Geology, London, 1905.

91. Gould, C. N., On a Series of Transition Beds from the Comanche to the Dakota Cretaceous in Southwest Kansas: Am. Jour. Sci, Ser. 4, Vol. 5, pp. $169-175,1898$.

92. Grabau, A., Types of Sedimentary Overlap: Geol. Soc. Am. Bull, Vol. 17, pp. $567-636,1906$.

93. Hall, James, Geology of lowa, Vol, 1, Part 1, pp. 143-145, 1858.

94. Hall, James, Observations on the Cretaceous Strata of the United States: Am. Jour, Sci., Ser. 2, Vol. 24, pp. 72-86, 1857.

95. Hawn, Frederick, The Trias of Kansas: St. Louis Acad. Sci. Trans, Vol. 1, pp. $171-172,1858$.

96. Hicks, Lewis E., The Dakota Group South of the Platte River in Nebraska (Abstr.): Proc. Amer. Assoc. Adv. Sci, Vol. 34, pp. 217-219, 1885 . See also Science, 6, p. 221, 1885.

97. Johnson, H. L., Correlation of Five Wells in Texas: Univ. of Texas, Bull. 3001, pp. 139-147, 1930.

98. Keyes, Charles Rollin, Annotated Bibliography of lowa Geology: Iowa Geol. Survey, Vol. XXII, 908 pp., 1913.

99. Keyes, Charles Rollin, Eastern Extension of the Cretaceous in Iowa: Iowa Acad. Sci. Proc. for 1890 and 1891, Vol. I, Part ii, p. 21, 1892.

100. Keyes, Charles Rollin, Iowan Cretacic Sequence (Abstr.): Science, n. S., Vol. 38, p. 241, 1913

101. King, Clarence, Systematic Geology, U. S. Geol. Explor. 40th Par., Vol. 1, pp. $298-305,1878$.

102. Knowlton, F. H, A Catalogue of the Mesozoic and Cenozoic Plants of North America: U. S. Geol. Surv. Buil. 696, 1919. 
103. Lee, W. T., Continuity of Some Oil-bearing Sands of Colorado and Wyoming: U. S. Geol. Surv. Bull. 751, pp. 1-22, 1923.

104. Lee, Willis T., Correlation of Geologic Formations Between East-Central Colorado, Central Wyoming and Southeastern Montana: U. S. Geol. Surv. Prof. Paper 149, pp. 17-23, 1927.

105. Leidy, Jos., Description of Remains of Reptiles and Fishes from the Cretaceous Formations of the Interior of the United States: U. S. Geol. Survey Terr., Vol. 1, pp. 266-310, 1873.

106. Lonsdale, E. H., Geology of Montgomery County, Iowa: Iowa Geol. Survey, Vol. IV, pp. 389-451, 1895.

107. Marcou, J., Notes on the Geology of Kansas and Nebraska: St. Louis Acad. Sci., Vol. 1, pp. 610-611, 1860.

108. Meek, F. B., and Hayden, F. V., Descriptions of New Organic Remains from the Tertiary, Cretaceous and Jurassic Rocks of Nebraska: Phila. Acad. Nat. Sci. Proc., Vol. 12, 1860, pp. 175-185, 1861.

109. Meek, F. B., and Hayden, F. V., Systematic Catalogue of Synonyms, etc., of Jurassic, Cretaceous, and Tertiary Fossils Collected in Nebraska Territory: Phila. Acad. Nat. Sci. Proc., Vol. 12, 1860, pp. 417-432, 1861.

110. Morton, Samuel G., Synopsis of the Organic Remains of the Cretaceous Group of the United States, 88 pp., ills., Phila., 1834. With appendix, catalogue of the fossil shells of the Tertiary formations of the United States, 8 pp. Additional observations, June, 1835.

111. Newberry, J. S., Notes on the Later Extict Floras of North America, with descriptions of some new species of fossil plants from the Cretaceous and Tertiary strata: Lyc. Nat. Hist. Annals, Vol. 9, pp. 1-76, 1868. See also Am. Jour. Sci., Ser. 2, Vol. 46, pp. 401-407, 1868.

112. Nicollet, J. N., Report Intended to Illustrate a Map of the Hydrographical Basin of the Upper Mississippi River. List of fossils belonging to several formations alluded to in the report, arranged according to localities, pp. 167-170: U. S. 26th Cong., 2d Sess., Sen. Doc. 237, 170 pp., map, 1843.

113. Nuttall, Thomas, Journal of Travels into the Arkansas Territory During the Year 1819, 296 pp. Phila., 1821. Reprinted with notes by Reuben Gold Thwaites as Vol. 13 of Early Western Travels, 1748-1846, Arthur H. Clark, 1905.

114. Owen, D. D., Geological Survey of Wisconsin, Iowa and Minnesota, and Incidentally a Portion of Nebraska Territory; made under direction of U. S. Treasury Dept., p. 195, Phila., 1852.

115. Phillips, John, Memoirs of William Smith, Biographical, 1844.

116. Piper, A. M., A Discussion of the Origin of Artesian Pressure. Paper by W. L. Russell, Econ. Geol., Vol. 23, pp. 683-696, 1928.

117. Reeside, F. B., Jr., The Fauna of the So-called Dakota Formation of Northern Central Colorado and Its Equivalent in Southeastern Wyoming: U. S. Geol. Surv. Prof. Paper 131, pp. 199-207, 1923.

118. Rubey, W. W., Origin of the Siliceous Mowry Shale of the Black Hills Region: U. S. G. S. Prof. Paper 154D, pp. 153-170, 1929.

119. Rubey, W. W., and Bass, N. W., The Geology of Russell County, Kansas: Kansas Geol. Survey, Bull. 10, 86 pp., 1925. 
120. Russell, W. L., The Origin of Artesian Pressure: Econ. Geol., Vol. 23, pp. 132-155, 1928.

121. Stanton, T. W., A Comparative Study of the Lower Cretaceous Formations and Faunas of the United States: Jour. Geol., Vol. 5, pp. 597-624, 1897.

122. Stanton, T. W., The Morrison Formation and Its Relation with the Comanche and Dakota Formations: Jour. Geol., Vol. 12, pp. 657-669, 1905.

123. Tester, A. C., Comanchean Fossils from the Glacial Drift of Iowa (abs.): Bull. G. S. A., Vol. 38, p. 233, 1927.

124. Tester, A. C., A Convenient Hydrometer: Science, N. S., Vol. 73, pp. 130, $131,1931$.

125. Tester, A. C., Measurement of Shapes of Rock Particles: Jour. of Sed. Petrology, Vol. 1, No. 1, pp. 3-11, 1931.

125a. Tester, A. C., and Bay, H. X., The Shapometer, a Device for Measuring the, Shapes of Pebbles: Science, N. S., Vol. 73, pp. 565, 566, 1931.

126. Trowbridge and Mortimore, Correlation of Oil Sands by Sedimentary Analysis: Econ. Geol., Vol. 20, pp. 409-423, 1925.

127. Ward, L. F., The Cretaceous Rim of the Black Hills: Jour. Geol., Vol. 2, pp. 250-266, 1894.

128. Wentworth, C. K., A Laboratory and Field Study of Cobble Abrasion: Jour. Geol., Vol. 27, pp. 507-521, 1919.

129. Wentworth, C. K., The Shape of Pebbles: U. S. Geol. Surv. Bull. 730, pp. 91-114, 1922.

130. Wentworth, C. K., Methods of Mechanical Analysis of Sediments: Univ. of Iowa Studies in Nat. Hist., Vol. 11, No. 11, N. S. 117, 1926.

131. Wilmarth, M. G., Geologic Time Classification of the U. S. Geological Survey, etc.: U. S. Geol. Surv. Bull. 769, 1925.

132. Wilson, Roy A., The Possibilities of Oil in South Dakota: Bull. 10, South Dakota Geol. Survey, pp. 54-60, 1922.

133. White, Charles A., Exogenous Leaves in the Cretaceous Rocks of Iowa: Am. Jour. Sci., Ser. 2, Vol. 44, p. 119, 1867.

134. White, Charles A., On the Occurrence of Later Cretaceous Deposits in Iowa: Amer. Geol., Vol. 1, pp. 221-227, ills., 1888. 


\section{DESCRIPTION OF PLATE III}

FIGURE A. Photomicrograph, zone 6a, Section 1, 1/8-1/16 mm. grade. Shows rounded zircon grain, mica, and a frosted quartz grain. Mag. $80 \mathrm{x}$ in 1.742 index liquid. Magnifications approximate.

Zone 6a, Section 1, Sioux City shale pit, marine fossiliferous bed of Dakota stage.

FIGURE B. Photomicrograph, zone 6a, Section 1, I/4-1/8 mm. grąde. Shows surface etching on quartz grain and grain of microcline. Mag. 100x.

FIGURE C. Photomicrograph, zone 6a, Section 1. Shows glauconite grains. X-nicols, Mag. 200x.

FIGURE D. Photomicrograph, zone 6a, Section 1. Shows fresh plagioclase feldspar in iron oxide cement. X-nicols, Mag. $200 \mathrm{x}$.

FIGURE E. Photomicrograph, zone 6a, Section 1. Shows fresh feldspars and quartzite grains in silt matrix. X-nicols, Mag. $200 x$.

FIGURE F. Photomicrograph, zone 6a, Section 1. Shows large rounded grain of quartzite and fresh feldspars in fine calcite matrix. X-nicols, Mag. 200x.

FIGURE G. Photomicrograph, zone 9, Section 1. Graneros sandstone. Shows spine and quartz grains in calcite matrix. X-nicols.

FIGURE H. Photomicrograph, zone 6a, Section 1. Shows basic feldspar alteration to calcite and quartz. X-nicols, Mag. 200x.

FIGURE I. Photomicrograph, zone 6a, Section 1. Shows feldspar alteration. X-nicols, Mag. 200x.

FIGURE J. Photomicrograph, zone 12, Section 3. Shows glauconite in center with small rhombic crystals of calcite. 


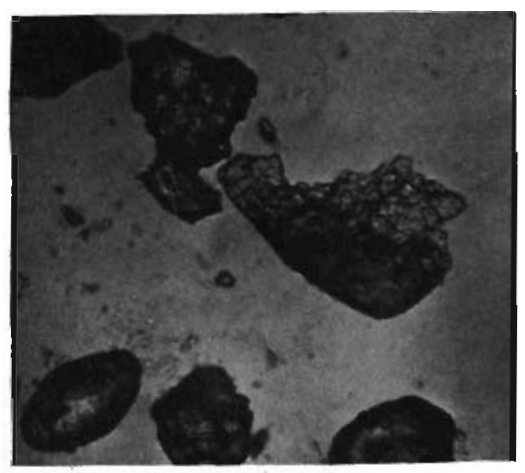

A

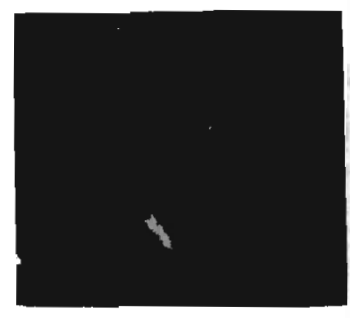

C

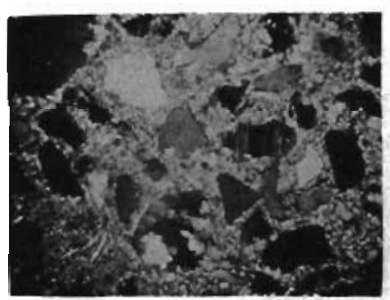

F

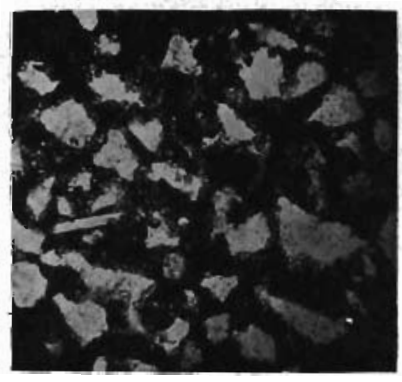

J

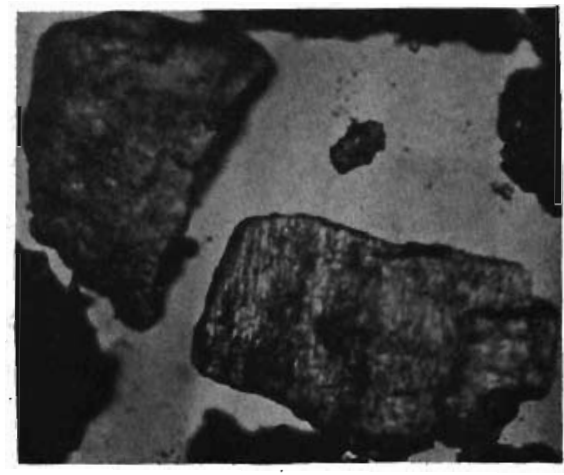

B

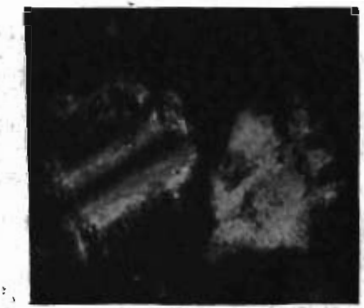

1

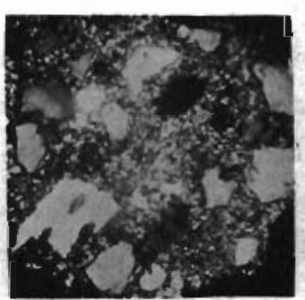

E

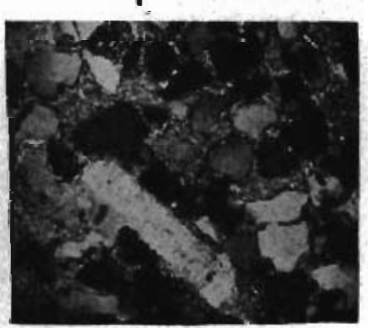

G

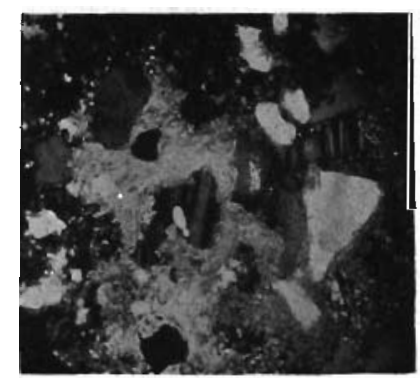

H 


\section{DESCRIPTION OF PLATE IV}

FIGURE A. Photomicrograph, zone 1, Section 6. Shows grain of glauconite in center. X-nicols, Mag. 200x.

FIGURE B. Photomicrograph, zone 8, Section 7. Shows much glauconite and pyrite in matrix of calcite. Polarizer only.

FIGURE C. Photomicrograph, zone 8, Section 7. Shows glauconite. X-nicols.

FIGURE D. Photomicrograph, zone 4, Section 7. Shows glauconite grain in circle near center of field. $1 / \mathrm{s}-1 / 16 \mathrm{~mm}$. grade in 1.742 index liquid.

FIGURE E. Photomicrograph, Section 9. Shows texture and shape of particles. X-nicols, Mag. $80 x$.

FIGURE F. Photomicrograph, Section 8. Shows triangular shaped large grain of chert (upper center). Mag. $84 \mathrm{x}$.

FIGURE G. Photomicrograph, zone 4, Section 10, 1/4-1/8 mm. grade. Shows sub-round grain in center and a large number of curvilinear grains of quartz. In 1.742 index liquid. Mag. 84x.

FIGURE H. Photomicrograph, zone 3, Section 10, $1 / 4-1 / 8 \mathrm{~mm}$. grade. Shows curvilinear grains of quartz with surface etching. In 1.742 index liquid. Mag. 84x.

FIGURE I. Photomicrograph, zone 1, Section $10, \mathrm{I} / 4-\mathrm{I} / 8 \mathrm{~mm}$. grade. Shows curvilinear and subangular quartz grains with surface etching. In 1.742 index liquid. Mag. 74x.

FIGURE J. Photomicrograph, zone 1 , Section $10, \pi / 4-1 / 8 \mathrm{~mm}$. grade. Shows typical curvilinear quartz grain in center. In 1.742 index liquid. Mag. $84 x$. 
Iowa Grologrcal Survey

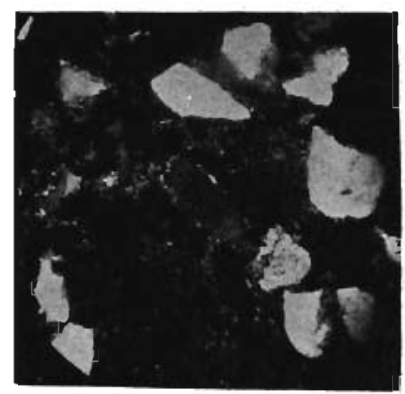

$\mathbf{A}$

Plate IV

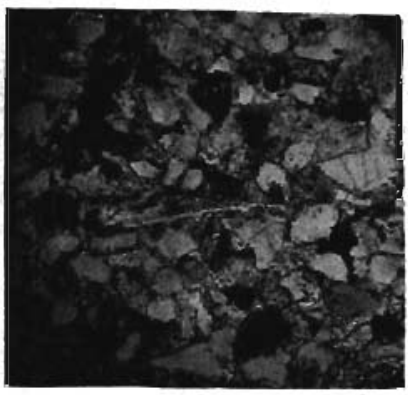

B

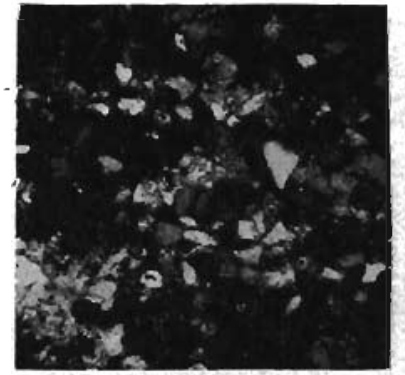

C

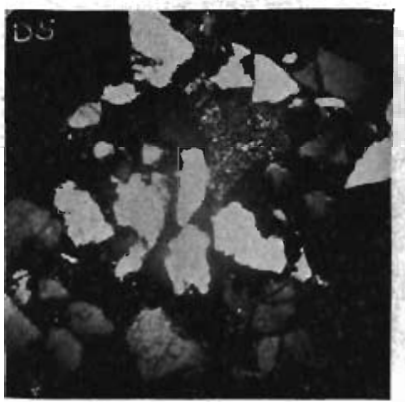

F

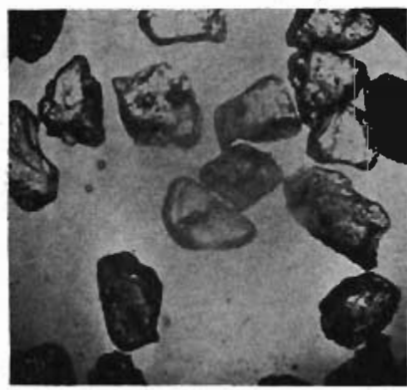

J

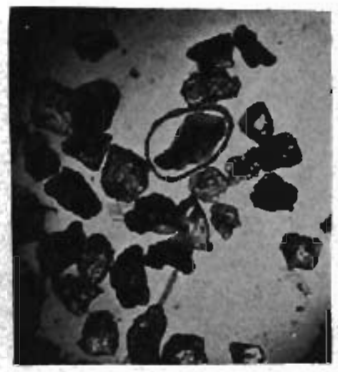

D

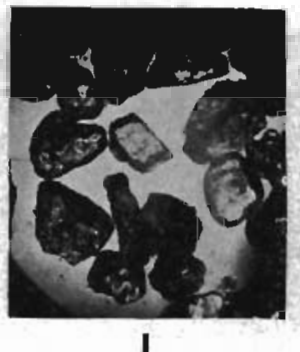

I

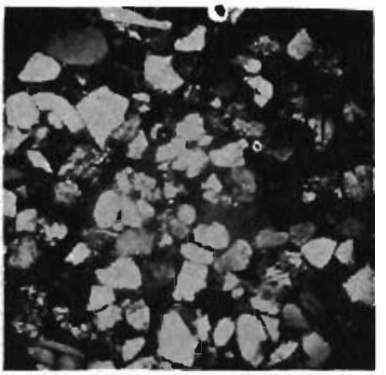

E

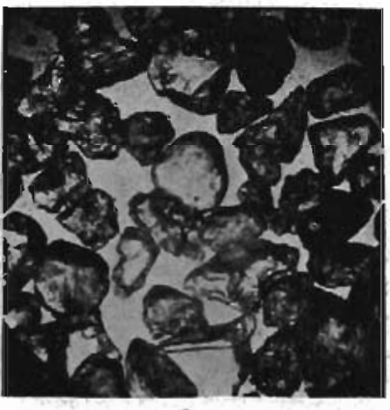

G

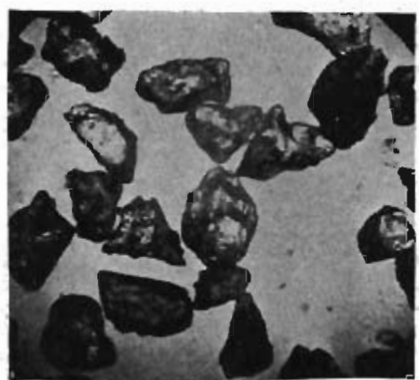

.H 



\section{INDEX}

\section{A}

Agassiz, Louis, cited, 315

Allen, Paul, and Biddle, N., cited, 312

Analyses, mechanical, of Dakota sands, 305

Analysis of Dakota sands, 274; laboratory methods used, 301

Analysis of sands, 287, 292, 298

Anatina, 226

Anchura, 226; kiowana, 227

Andromeda parlatorii, 265; pfaffiana, 265

Anomia, 226

Aowa creek, Dakota beds on, 205, 247

Araliopsoides cretacea, 266

Arcopagella ? macrodonta, 224, 225

Arkansas, age of fossils from, 207

Ashland, Nebraska, Dakota beds near, 260

"Ayoway" (Aowa) river, section at, 208

\section{B}

Baculites, 206, 207

Bain, H. Foster, cited, 219, 241, 243, 317,318 ; study of Dakota beds, 219; use of terms, 232

Ballou Brick Company, pit of, 245

Barbour, E. H., work of, on Lewis and Clark journals, 205

Bartsch, Paul, cited, 219, 317; study of Dakota beds, 219

Bass, N. W., cited, 266, 320; study of Dakota beds, 266

Bay, H. X., cited, 321

Beatrice, Nebraska, Dakota beds near, 260

Bellvue, Colorado, fossils from, 227

Beloit, Kansas, fossils from, 226

Belvidere beds, age, 282; character, 268; history, 272; relation to Dakota stage, 282, 283; Washita age of, 200

Berg, K., cited, 318

Berry, E. W., cited, 224, 225, 265, 266, 318,319 ; study of Dakota beds, 224; use of terms, 233

Bibliography of Dakota stage, 312

Big Sioux river, Calvin's section on, 217; fossils from, 210; sections on, 216,241
Black Hills, Dakota beds in, 228

Boulders, Mentor, in Kansan drift, 229

Bradbury, John, cited, 205, 313; study of Dakota beds, 205

Brongniart, Alexandre, cited, 319

Brown, I. C., cited, 308, 319

Burchard, E. F., cited, 220, 221, 249, 318 ; study of Dakota beds, 220

\section{Callista ?, 235}

Calvin, S., cited, 219, 220, 230, 317, 319; law of deposition, 218; section on Big Sioux river, 217; study of Dakota beds, 217

Capellini, J., cited, 315 ; study of Dakota leaves by, 213,215 .

Cardium, 237

Carneiro, Kansas, Dakota beds near, 269

Cayeux, L., cited, 319

Cenomanian of Europe, age, 214, 224, 228

Centrifuge, use, 308

Cervillia, 226

Chalkstone horizon, age, 216

Chamberlin and Salisbury, use of terms, 233

Cheyenne sandstone, age, 225

Clark, Captain, study of Dakota beds, 204

Cleland, H. F., use of terms, 233

Coburg, Iowa, Dakota beds near, 256259, 281

Colorado, fossils from, 227

Colorado and Dakota stages, division, 238,242

Comanchean series, Dakota stage in, 284; in Kansas, 223, 267

Comanchean time, seas of, 226

Condra, G. E., cited, 221, 249, 318; study of Dakota beds, 221

Cone-in-cone in Kansas, 267

Cones probably Alnus, 266

Conybeare and Phillips, division of Cretaceous by, 207

Cope, E: D., cited, 316

Corbicula ? subtrigonalis, 237

Corbula, 226; hicksii, 219, 225

Coues, E., cited, 319 
Cox, E. P., cited, 310, 311, 319

Cretaceous, Lower, studies of, 200

Cretaceous fossils from Missouri country, 205

Cretaceous rocks, controversy regarding age of, 212; description of, 202; European, correlation with strata of United States, 214; exposures, 200; of New Jersey, 212; of Nebraska, 210; see Dakota

Cretaceous system, Dakota stage in, 284

Crill limestone, named by Keyes, 223

Crill Mill section, Dakota beds at, 241, 279

Crocodile from Dakota beds, 226

Cross-bedding in Dakota stage, 272

Currents depositing Dakota beds, direction, 280

Cuvier, Georges, cited, 319

Cyprina, 211

Cyrena, 226; arenarea, 202, 214; dakotensis, 224, 237; novamexicana, 214

\section{D}

Dakota and Belvidere beds, relations, 282; and Benton, division between, 223; and Colorado stages, division, 238, 242; and Graneros, division, 238, $241,278,282$; and Washita beds, relations, 227

Dakota City, Nebraska, Dakota rocks near, 233

Dakota county, Nebraska, Dakota beds in, 202

Dakota embayment, 282

Dakota flora, age, 225; origin, 219, 220; plants of, 265,266

Dakota fossils, lists, 219, 225, 237; relations, 201

"Dakota group", age, 227; named by Meek and Hayden, 214; term first applied, 202; original name, 231; use of term, 233

Dakota sands analyses, 240, 274; laboratory methods used in analysis, 302 ; mechanical analysis, 305 ; mineral determination, 309 ; mineral separation, 307 ; photomicrographs, 322 -
325; preparation of samples, 304; sampling, 303; shape analyses, 309; splitting samples, 304

Dakota sandstone lenses, origin, 270

Dakota stage, age, 201, 210, 222, 224 , 225, 228; base, 278; beds named from town, 202; bibliography, 312 ; character, 276, 278; in Kansas, 264; conditions of deposition, 275; conformable with Graneros, 275; contact with Pennsylvanian, 221; with Permian, 263; fossils from, 223, 235, 237, 275; glauconite in, 277; interest in, 200; leaves from, $243 \mathrm{ff}, 265,266,280$; lenticular character, 229; lignite in, 279; limits, 220; oblique beds in, 229 ; origin, 214, 218, 220-223, 228, 229, 280; "peanut" gravels, origin, 301; plants from, 265, 282; rock terms for, 231; sections, $240 \mathrm{ff}$; along Missouri river, 200; in Iowa, 235ff; in Kansas, 262, 281 ; in Nebraska, 260, 281; near Coburg, Iowa, 256-259; near Decatur, Nebraska, 252; near Fairbury, Nebraska, 261; near Lewis. Iowa, 255; near Homer, Nebraska, 248-251; near Ponca, Nebraska, 246-248; near Sargeant Bluff, 245; near Sioux City, 235, 275; near Washington, Kansas, 263; near Westfield, Iowa, 241; study by Bartsch, 219; by Berry, 224; by Burchard, 220; by Bradbury, 205; by Calvin, 217; by Capellini, 213; by Condra, 221; by Darton, 221; by Gould, 219; by Hall, 209; by Hawn, 213; by Heer, 215; by Hicks, 219; by Keyes, 223; by Lee, 227; by Lesquereux, 215; by Lewis and Clark, 204; by Long, 205; by Lyell, 208; by Marcou, 208, 213; by Meek and Hayden, 209, 214; by Morton, 207; by Newberry, 211, 213; by Nicollet, 208; by Nuttall, 205; by Owen, 208; by Piper, 229; by Reeside, 227; by Russell, 228; by Stanton, 225; by Tester, 229; by Todd, 216, 221, 222; by Twenhofel, 223; by Vanuxem, 207; by White, 215, 219; thickness, 216, 221, 278; type locality, 201 
Dakota stage in Upper Mesozoic sequence, 283

Dammara borealis, 265

Dammarites cf. emarginatus, 266

Dana, James D., use of terms, 232

Darton, N. H., cited, 221, 318, 319; study of Dakota beds, 221; use of terms, 232

Decatur, Nebraska, Dakota beds near, 204, 252

Denmark, Kansas, fossils from, 226

Diabase dikes, origin of Dakota beds from, 277

\section{$\mathbf{E}$}

Elk Point Ferry Landing, Dakota beds at, 246, 279

Emmetsburg, well at, Dakota beds in, 217

Emmons, R. C., cited, 309, 319

Endicott, Nebraska, Dakota beds near, 260

Era of time, meaning, 232

Eucalyptus Dakotensis, 265

Evans, John, work of, 208; study of Dakota beds, 208

\section{$\mathbf{F}$}

Fairbury, Nebraska, Dakota beds near, 261

Fauna of Dakota stage, 283

Featherstonhaugh, G. W., study of Dakota beds, 208

Flora of Dakota stage, 265, 266, 283

Floyd, Sergeant, death of, 204

Fluvial sorting and deposition, study of, 285-301

Foraminifera, 235, 241, 247

Formation, meaning of, 231

Fort Benton group, named by Meek and Hayden, 231

Fort Dodge gypsum beds, called Cretaceous by Keyes, 219

Fossils, correlation by use of, 210

Fossils, Cretaceous, from Missouri country, 205

Fossils from Dakota stage, 235, relations, 201

Fredericksburg time, seas of, 226

Fuson, oblique beds in, 229
Geikie, Sir Archibald, 319

Glauconite in Dakota stage, 237, 252, 275,277

Goniobasis jeffersonensis, 219

Gould, C. N., cited, 219, 220, 225, 249, $317,318,319$; study of Dakota beds, 219 ; use of terms, 232,233

Grabau, A. W., cited, 223, 319; use of terms, 232

Graneros beds, near Ponca, 247, 248; thickness, 229

Graneros and Dakota, divisions between, 220, 278; relations, 275, 282

Greenhorn beds at Sioux City, 238

Green sands of Europe, age, 214

Group, meaning of, 231

Gryphaea, 207; corrugata, 207

\section{$\mathbf{H}$}

Hall, James, cited, 209, 212, 314, 319; study of Dakota beds, 209

Hamites ?, 207

Hastings, Neb., Dakota beds near, 260

Hawarden shales, named by Keyes, 223

Hawn, Frederick, cited, 213, 319; study of Dakota beds, 213

Hayden, F. V., cited, 202ff, 314, 315, 316, 320; study of Dakota beds, 202; see also Meek and Hayden

Heer, Oswald, cited, 211-213, 315; study of Dakota leaves by, 212, 215

Hicks, Lewis E., cited, 219, 262, 317 , 319; study of Dakota beds, 219

Hills, R. C., use of terms, 233

Homer, Nebraska, Dakota beds near, $220,248-250,278$

\section{I}

Inoceramus, $208,235,241,246,247$; comancheanus, 227 ; problematicus, 217

Inoceramus beds named by White, 215

Iowa, Dakota sections in, 235, 255; Mentor boulders in, 229

\section{J}

Jackson, Nebraska, fossils from, 225

James, Edwin, cited, 206, 207, 313; study of Dakota beds, 206

Johnson, H. L., cited, 307, 319 
$\mathbf{K}$

Kanopolis, Kansas, Dakota beds near, 268

Kansan drift, Mentor boulders in, 229

Kansas, characteristics of Dakota beds, 265; Comanchean formations of, 223; Dakota stage in, 211,219, 262, 281; fossils from, 226; fossils plants from, 265

Kansas Geological Survey, work under, 199

Keyes, Charles Rollin, cited, 206, 219, 223, 230, 317, 319; study of Dakota beds, 219 ; use of terms, 232

Kiowa-Mentor series, age, 223; relation to Dakota stage, 283

King, Clarence, cited, 319 ; use of terms, 232

Knowlton, F. H., cited, 319

L

Laboratory methods used in analysis of Dakota sands, 302

Lakota, oblique beds in, 229

Leaves from Dakota stage, 243ff, 265 , 266,280 ; study of, $211-215$

Le Conte, J., use of terms, 232

Lee, W. T., cited, 227, 320; study of Dakota beds, 227; use of terms, 232, 233

Leidy, Jos., cited, 320

Le Mars, well at, Dakota beds in, 217.

Lenses in Dakota sandstone, 229, origin, 270

Lesquereux, Leo, cited, $215,220,316$, 317; study of Cretaceous leaves by, 215

Lewis, Capt., minerals studied by, 205; study of Dakota beds, 205

Lewis, Iowa, Dakota beds near, 255 , 281

Lewis and Clark expedition, reprints of original journals, 204

Lignite beds of Dakota stage, 220, 276, 279; at Sergeant Bluff, 246

Liriodendropsis simplex, 265

Little River, Kansas, Dakota beds near, 267

Llano Estacado, formations in, 212

Logan, W. N., use of terms, 232
Long expedition, study of Dakota beds, 206

Lonsdale, E. H., cited, 258, 320: study of Dakota beds, 258

Lyell, Charles, cited, 208; study of Dakota beds, 208

\section{M}

Maclure, William, cited, 313

Mactra siouxensis, 214, 224, 237

Maha village, strata near, 206

Marcou, Jules, cited, 208, 212, 213, 314316,320 ; study of Dakota beds, 213

Margarita, 237

Margaritana nebrascensis, 202, 224

Marine molluscan fauna in Dakota stage, 275

Marquette member, character, 268; history, 272

Martesia ? sp., 225

Maximilian von Wied, Prince, study of Dakota beds, 208

Meek, F. B., cited, 202, 205, 209, 214, $224,249,314,315,316,320$; study of Dakota beds 202-214

Meek and Hayden, cited, 202, 211-214, 231; sections along Missouri river, 202, 209; study of Dakota beds, 202214; use of terms, 232

Mentor-Dakota sequence, 224

Mentor sandstone, boulders in Kansan drift, 229; history, 272; in Kansas, 267 ; relation to Dakota stage, 226 , 281,283

Mentor time, seas of, 226

Miller, use of terms, 233

Mineral determinations of $\mathrm{Dak}$ ot a sands, 309

Mineral separation of Dakota sands, 307

Minerals from Sioux City region, 205

Missouri river, age of fossils from, 207; Cretaceous fossils from, 205; Dakota beds along, 200, 204, 247; travel along, 200

Modiolus, 226

Moore, R. C., use of terms, 233

Morrison formation, age, 228

Mortimore, M. E., cited, 310, 321 
Morton, Samuel G., cited, 207, 313, 320: study of Dakota beds, 207

Mowry beds, age, 228

Myrica longa, 265

Myrsine gaudini, 265

$\mathbf{N}$

Natural Corral, Kansas, Dakota beds at, 268

Nebraska, Cretaceous section of, 210; Dakota beds in, 202, 219, 221, 246, $248-250,260,281$; fossils from, 225

Neocomian of Europe, age of, 214

Newberry, J. S., cited, 211, 213, 215, 320 ; study of Dakota beds, 211

Newcastle member, age, 228

New Jersey, Cretaceous rocks of, 212

New Mexico, age of fossils from, 207

Nicollet, J. N., cited, 208, 313, 314, 320; study of Dakota beds, 208

Niobrara division, named by Meek and Hayden, 231

Nishnabotany sandstone, named by White, 215

Nishnabotna shales, named by Keyes, 223

Nuttall, Thomas, cited, 205, 313, 320; study of Dakota beds, 205

\section{0}

Ostrea, 206; 207, 225, 226; congesta, 217 Otodus, 217

Owen, D. D., cited, 208, 314, 320; study of Dakota beds, 208

\section{$\mathbf{P}$}

"Peanut" gravels of Dakota stage, origin, 301

Pectunculus, 211, 214

Pennsylvanian rocks, contact with $\mathrm{Da}$ kota beds, 221

Period of time, meaning, 231

Permian rocks, contact with Dakota beds, 263

Pharella, 214, 225; dakotensis, 202, 224

Phillips, John, cited, 320

Photomicrographs of Dakota sands, 322-325
Piper, A. M., cited, 229, 320; study of Dakota beds, 229

Plants of Dakota stage, 265, 275, 282; from Kansas, 265

Plaster of paris channel, experiment in, 297

Plymouth county, section in, 241

Ponca, Nebraska, Dakota beds near, 205, 246, 247

Ponca sandstone, named by Keyes, 223

Prospect Hill, Sioux City, Dakota beds at, 243,278

Protocardia texana, 237

Protophyllocladus subintegrifolius, 265

Protophyllum, 265

Pseudomelania ? 225, 226

Pteria salinensis, 227

Ptychodus, 217

"Puddingstone" in Dakota beds, 258

Purgatoire beds, age, 228

Pyrgulifera meekii, 219

\section{$\mathbf{R}$}

Red Oak, Iowa, Dakota beds near, 256

Reeside, J. B., Jr., cited, 227, 320; study of Dakota beds, 227; use of terms, 233

Rhamnites apiculatus 265

Ripple marks in Dakota sandstone, 244, 251

Riverside, exposure at, 235

"Rocks,"The", Kansas, Dakota beds at, 267

Rocktown Channel Sandstone member, 271, 282; origin, 266

Rothrock, E. P., use of terms, 233

Rubey, W. W., cited, 266, 320; study of Dakota beds, 266

Russell, W. L., cited, 321

\section{$\mathbf{S}$}

Sampling of Dakota sands, 303; preparation of samples, 304

Sands, analysis of, 287, 292, 298

Sandstone lenses of Dakota stage, origin, 270

Sassafras acutilobum, 265; cretaceum, 266; (Araliopsis) mirable, 266

Say, Thomas, study of Dakota beds, 206 
Schuchert, Charles, use of terms, 233

Senonian of Europe, age of, 214

Sergeant Bluff, Dakota beds at, 245, 278; leaves from Dakota beds at, 219

Sergeant shales, named by "Keyes, 223

Series, meaning of, 231

Shape analysis of Dakota sands, 309

Sioux City, Cretaceous at, 217; Dakota beds near, 216, 235, 240, 243, 275, 278; Lewis and Clark near, 203; well at, Dakota beds in, 217

Sioux City Brick Company, pit of, 235

"Sioux" group as name for Dakota beds, 203

Sioux quartzite, origin of Dakota beds from, 276

Solen, 211

South Dakota, Dakota beds in, 221; diabase dikes in, 277; Sioux quartzite in, 276

Splitting samples of Dakota sands, 304

Stanton, T. W., cited, 225, 226, 266, 283,

318,321 ; study of Dakota beds, 225

Stone Park, Sioux City, Dakota beds at, 216, 240

Stream table at University of Iowa, 286

Stream table experiment No. I, 286; No. II, 289; No. III, 296

System of rocks, meaning, 231

\section{$\mathbf{T}$}

Tekamah, Nebraska, beds near, 252

Tellina, 226

Tester, A. C., cited, 229, 311, 321; study of Dakota beds, 199, 229

Thwaites, Reuben Gold, cited, 204, 312

Todd, J. E., cited, 216, 221, 222, 317, 318; study of Dakota beds, 216 ; use of terms 233

Trigonarca salinaensis, 237; siouxensis, $202,224-226$

Trinity time, seas of, 226

Trowbridge, A. C., and Mortimore, M. E., cited, 310,321

Turonian of Europe, age of, 214

Turritella kansasensis, 237

Turtle from Dakota beds, 226

Twenhofel, W. H., cited, 200, 223, 226,
$268,281,318$; study of Dakota beds, 223; use of terms, 233

Unconformity in Dakota beds, 253

Unio barbouri, 219

University of Iowa, stream table at, 286

Upper Cretaceous, base of, 224

\section{V}

Vanuxem, Lardner, cited, 207, 313; study of Dakota beds, 207

Viviparus hicksii, 219, 226

Volutoderma, 226

\section{W}

Ward, L. F., cited, 317, 321

Washington, Kansas, Dakota beds near, 262

Washita age of Belvidere formation, 200

Washita formation, age, 224, 228; fossils from, 227

Washita and Dakota beds, relations, 227

Washita-Kiowa beds, age, 228

Washita-Kiowa-Mentor series, relation to Dakota stage, 283

Wentworth, C. K., cited, 304, 305, 311, 321

Westfield, section near, 241

White, Charles A., cited, 215, 216, 219, $262,316,317,321$; names given to Cretaceous beds by, 215; study of Dakota beds, 215

White, David, use of terms, 232

Widdringtonites reichii, 265

Wilmarth, M. Grace, cited,.231, 321

Wilson, Roy A., cited, 321

Windom member in Kansas, 267

Woodbine flora of Texas, relations, 266

Woodbine formation, age, 225

Woodbury county, Iowa, Dakota beds exposed in, 235

Woodbury sandstones and shales, named by White, 215

\section{$\mathbf{X}$}

Xylanthrax, 206 